ÍRIS ARANTES DE CASTRO

\title{
IMPORTÂNCIA DO COMPONENTE C5 DO SISTEMA COMPLEMENTO PARA O CONTROLE DE LEPTOSPIROSE IN VIVO EM MODELOS MURINOS
}

\begin{abstract}
Dissertação apresentada ao Programa de Pós-Graduação em Imunologia do Instituto de Ciências Biomédicas da Universidade de São Paulo, para obtenção do Título de Mestre em Ciências.
\end{abstract}


ÍRIS ARANTES DE CASTRO

\section{IMPORTÂNCIA DO COMPONENTE C5 DO SISTEMA COMPLEMENTO PARA O CONTROLE DE LEPTOSPIROSE IN VIVO EM MODELOS MURINOS}

Dissertação apresentada ao Programa de Pós-Graduação em Imunologia do Instituto de Ciências Biomédicas da Universidade de São Paulo, para obtenção do Título de Mestre em Ciências.

Área de concentração: Imunologia

Orientadora: $\operatorname{Prof}^{\mathrm{a}} \operatorname{Dr}^{\mathrm{a}}$ Lourdes Isaac

Versão corrigida. A versão original eletrônica encontra-se disponível tanto na Biblioteca do ICB quanto na Biblioteca Digital de Teses e Dissertações da USP (BDTD) 
DADOS DE CATALOGAÇÃO NA PUBLICAÇÃO (CIP)

Serviço de Biblioteca e Informação Biomédica do

Instituto de Ciências Biomédicas da Universidade de São Paulo

reprodução não autorizada pelo autor

Castro, Íris Arantes de.

Importância do componente C5 do Sistema Complemento para o controle de leptospirose in vivo em modelos murinos / Íris Arantes de Castro. -- São Paulo, 2014.

Orientador: Profa. Dra. Lourdes Isaac.

Dissertação (Mestrado) - Universidade de São Paulo. Instituto de Ciências Biomédicas. Departamento de Imunologia. Área de concentração: Imunologia. Linha de pesquisa: Sistema Complemento.

Versão do título para o inglês: Role of complement component C5 to in vivo leptospirose control in murine models.

$\begin{array}{lllll}\text { 1. SistemaComplemento } & \text { 2. C5 } & 3 \text {. Infecção } & 4 \text {. Leptospira interrogans }\end{array}$ 5. Resposta inflamatória 6. Camundongo I. Isaac, Profa. Dra. Lourdes II. Universidade de São Paulo. Instituto de Ciências Biomedicas III. Título. 
Candidato(a):

Título da Dissertação:

Orientador(a):
Íris Arantes de Castro.

Importância do componente C5 do Sistema Complemento para o controle de leptospirose in vivo em modelos murinos.

A Comissão Julgadora dos trabalhos de Defesa da Dissertação de Mestrado, em sessão pública realizada a ...................., considerou
( ) Aprovado(a)
( ) Reprovado(a)
Examinador(a): Assinatura:
Nome:
Instituição:
Examinador(a): Assinatura:
Nome:
Instituição:
Presidente: Assinatura:
Nome:
Instituição:




\title{
APROVAÇÃO DO COMITE DE ÉTICA
}

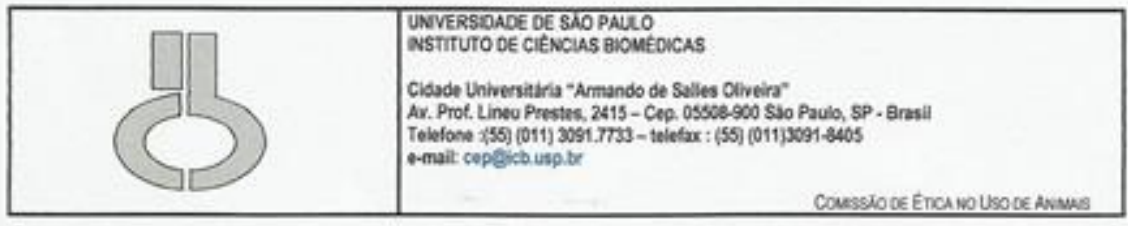

Decl. CEUA.004/2012

\author{
DECLARAÇÃO
}

Em adendo ao Certificado 061/10/CEUA, datado de 09.06.2010 e por solicitaçăo da Profa. Dra. Lourdes Isaac, responsável pela linha de Pesquisa, autorizo a inclusāo do aluno Iris Arantes de Castro ao Projeto de Pesquisa "Sistema Complemento e Patogenicidade de Leptospiras: Mecanismos de Ativaçăo e Escape, Identificaçăo de Ligantes Bacterianos, Caracterização de Proteases e Estabelecimento de Modelo Murino in vivo", uma vez que se trata de utilizaçẫo da mesma espécie animal e de métodos experimentais similares ao referido certificado.

Såo Paulo, 27 de janeiro de 2012.

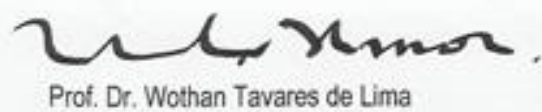

Coordenador da CEUA ICB/USP 


\section{AGRADECIMENTOS}

Aos meus pais e minhas irmãs, por tudo o que representam para mim, pelo apoio em todos os momentos, e sem os quais eu não seria o que sou nem estaria onde estou agora.

A Prof. Dr. Lourdes, que me aceitou no laboratório e confiou a mim a execução deste projeto, permitindo que eu crescesse profissionalmente e aprendesse não apenas a "executar tarefas", mas a refletir sobre o que está sendo realizado.

A Dr. Angela Barbosa, pela ajuda oferecida durante o projeto.

Aos professores do Departamento de Imunologia, pelas aulas, discussões e toda a ajuda fornecida nesses últimos três anos.

A todos os funcionários do departamento e do instituto, pelo fornecimento e manutenção dos camundongos utilizados neste projeto, o auxílio fornecido desde a inscrição para a prova de ingresso no programa até a entrega desse texto aos professores que compõem a banca, e pela manutenção de um espaço agradável onde pude passar bons momentos.

A Fapesp pelo auxílio financeiro fornecido durante toda a execução do projeto.

Ao CNPq pelo auxílio financeiro fornecido no início do mestrado.

A BioClin pelo fornecimento dos kits para dosagem de parâmetros bioquímicos no soro dos camundongos.

A Lorena Bavia, companheira de bons e maus momentos que me recebeu no laboratório e foi muito importante para a minha formação.

A todos os colegas e ex-colegas do laboratório (José Antônio, André, Leandro, Alfredo, Marlene, Tatiana, Adriana, Mónica, Karina, Daniella, Lorena), pela ajuda, as risadas e os bons momentos que passamos no laboratório. 
Aos colegas do departamento e do programa em imunologia, pelas conversas e risadas nos corredores.

Aos ex-colegas de graduação, que mesmo seguindo direções diferentes continuam próximos, sempre ajudando quando possível.

Ao Prof. Dr. Sílvio de Arruda Vasconcellos, pelo fornecimento das leptospiras utilizadas nas infecções dos camundongos.

A Zenaide, pela paciência em conciliar seu trabalho com os períodos de infecção dos camundongos e a ajuda oferecida constantemente para facilitar a execução deste projeto.

Ao Prof. Dr. Carlos Peleschi Taborda, por permitir que eu utilizasse o biotério do departamento de microbiologia para manusear os camundongos infectados.

Ao Prof. Dr. Thales de Brito, pela análise histopatológica dos camundongos e e todo o conhecimento que foi passado nesse período.

A Ana Maria, pela realização das reações de imuno-histoquímica e as conversas que tivemos durante os experimentos.

A todas as pessoas que participaram deste projeto, sem as quais não seria possível executá-lo.

Ao Paulo Albe pela confecção das lâminas histológicas.

A Rosana Prisco pela ajuda com a análise estatística dos resultados. 
Dois senhores pescavam a beira de um rio quando observaram um macaco voando a sua direita. Após certo tempo de paz, observaram outro macaco voador. Ao observar o terceiro macaco voador, um dos senhores perguntou para o outro: - "E aí?" - ao que seu amigo respondeu: - "Deve que o ninho deles é para lá".

Aula de estatística com Júlio C. R. Pereira 


\section{RESUMO}

CASTRO, IA. Importância do componente C5 do Sistema Complemento para o controle de leptospirose in vivo em modelos murinos. [dissertação (Mestrado em Imunologia)]. São Paulo: Instituto de Ciências Biomédicas, Universidade de São Paulo; 2014.

Camundongos são considerados animais resistentes à infecção por leptospiras patogênicas, enquanto hamsters e cobaias têm sido os animais de escolha para se estudar a patogenicidade desta infecção. Poucos estudos têm sido feitos em modelos murinos para se entender os mecanismos imunes efetores contra este tipo de bactéria. Considerando-se que o Sistema Complemento é fundamental para a eliminação deste patógeno in vitro, investigamos se camundongos C5 deficientes seriam mais suscetíveis à infecção pela Leptospira interrogans sorovar Kennewicki estirpe Pomona Fromm (LPF) do que camundongos C5 normais. Empregamos as linhagens isogênicas A/J C5 $\left(\mathrm{A} / \mathrm{J} \mathrm{C} 5\right.$ deficiente - $\left.\mathrm{C}^{-1-}\right)$ e $\mathrm{B} 6 \mathrm{C}^{+}(\mathrm{C} 57 \mathrm{~B} 1 / 6$ $\mathrm{C} 5$ suficiente $-\mathrm{C}^{+/+}$) e os camundongos congênicos A/J $\mathrm{C}^{+}$e B6 $\mathrm{C}^{-}$, ambos gerados em nosso laboratório, para este estudo de infecção in vivo. Camundongos C5 deficientes, independente da linhagem, possuem menor porcentagem de linfócitos $\mathrm{T} C D 8^{+}$na circulação periférica do que os animais $\mathrm{C} 5$ suficientes, enquanto $\mathrm{B} 6 \mathrm{C}^{-}$possui menor porcentagem de linfócitos $\mathrm{T} \mathrm{CD}^{+}$que $\mathrm{B} 6 \mathrm{C}^{+}$. Camundongos $\mathrm{B} 6 \mathrm{C}^{-}$infectados por $\mathrm{LPF}$ possuem menores níveis de TNF, IL-6, IL-10, IL-12p40 e IL-12p70 no rim, enquanto animais A/J C5 apresentam maiores concentrações de TNF e IL-6 no rim que A/J C5 $5^{+}$. Embora a presença de C5 não tenha influenciado a capacidade dos camundongos de eliminar as leptospiras do organismo, sua presença em animais B6 agravou as lesões hepáticas causadas por estes patógenos, mostrando um efeito dependente de $\mathrm{C} 5$ e do fundo genético dos camundongos. $\mathrm{O}$ número de leucócitos presentes na circulação periférica, bem como as proporções de neutrófilos, monócitos e linfócitos B foram influenciados somente pelo fundo genético das linhagens e pelo tempo de infecção. Esse comportamento também foi observado no desenvolvimento de esplenomegalia e para a síntese de citocinas pró-inflamatórias no sangue (IFN- $\gamma$, TNF- $\alpha$ e IL-6). A análise histopatológica dos órgãos dos camundongos confirmou a presença de lesões pulmonares em todas as linhagens e a proliferação de linfócitos $\mathrm{T}$ e $\mathrm{B}$ nos folículos linfoides associados à bainha periarteriolar presentes no baço dos camundongos, independente de C5. Nossos resultados mostraram a influência de C5 em poucos dos parâmetros analisados, os quais poderiam diminuir a capacidade de resposta imune dos camundongos $\mathrm{C5}^{-}$durante a infecção por leptospiras. Contudo, estas diferenças não foram suficientes para afetar a capacidade dos camundongos em controlar esta infecção, sugerindo uma importância relativamente pequena de C5 neste modelo.

Palavras-chave: Sistema Complemento. C5. Leptospira interrogans. Resposta inflamatória. Camundongo. 


\begin{abstract}
CASTRO, IA. Role of complement component C5 to in vivo leptospirose control in murine models. [Masters thesis (Immunology)]. São Paulo: Instituto de Ciências Biomédicas, Universidade de São Paulo; 2014.

Mice are considered resistant to infection by pathogenic leptospires, while hamsters and guinea pigs have been considered resistant. Few studies using murine models have been used to understand the immune effector mechanisms against Leptospira genus. Since Complement System is important to eliminate leptospiras in vivo we wondered if C5 deficient mice would be more susceptible to infection by Leptospira interrogans serovar Kennewicki type Pomona Fromm (LPF) than C5 sufficient mice. In this study we have used the isogenic strains A/J C5 (A/J C5 deficient $\left.-\mathrm{C}^{-/-}\right)$and $\mathrm{B} 6 \mathrm{C}^{+}\left(\mathrm{C} 57 \mathrm{~B} 1 / 6 \mathrm{C} 5\right.$ sufficient $\left.-\mathrm{C}^{+/+}\right)$and the congenic strains $\mathrm{A} / \mathrm{J} \mathrm{C}^{+}$e $\mathrm{B} 6 \mathrm{C}^{-}$, both generated at our laboratory. Independent of the strain, $\mathrm{C} 5$ deficient mice have lower percentage of $\mathrm{T} \mathrm{CD}^{+}$lymphocytes in peripheral circulation than $\mathrm{C} 5$ sufficient mice, while B6 $\mathrm{C}^{-}$mice have lower percentage of $\mathrm{T} \mathrm{CD}^{+}$lymphocytes than $\mathrm{B} 6$ $\mathrm{C}^{+}$. B6 $\mathrm{C}^{-}$mice infected by LPF present lower levels of TNF, IL-6, IL-10, IL-12p40 and IL-12p70 in the kidney, while A/J C5 mice present higher concentrations of TNF and IL-6 in the kidney than $\mathrm{A} / \mathrm{J} \mathrm{C5}{ }^{+}$. Although the component $\mathrm{C} 5$ apparently is not important to eliminate LPF in the liver and spleen of mice, the presence of this protein in B6 infected mice increased lesions in the liver of infected animals. The number of leukocytes in peripheral circulation and the percentage of neutrophils, monocytes and B lymphocytes were influenced only by genetic background of the strains. In addition, splenomegaly and concentration of pro-inflammatory cytokines in serum (IFN- $\gamma$, TNF- $\alpha$ and IL-6) were not influenced by C5. Histopathologycal analysis confirmed the presence of lung lesions in all mice strains and proliferation of lymphocytes in splenic B-cell corona, independently of C5. Our results showed a minor participation of $\mathrm{C} 5$ in the parameters analyzed, which could reduce the immune response of $\mathrm{C}^{-}$mice. However, no significant differences between $\mathrm{C}^{+}$and $\mathrm{C}^{-}$mice enough to control the infection by LPF were observed suggesting that $\mathrm{C} 5$ is not important in this in vivo experimental model.
\end{abstract}

Keywords: Complement system. C5. Leptospira interrogans. Inflammatory response. Mouse. 


\section{LISTA DE ILUSTRAÇÕES}

Figura 1 - Ciclo de infecção da leptospirose 20

Figura 2 - Modelo do desenvolvimento clínico da leptospirose com indicação de sintomas presentes nos estágios inicial e tardio da infecção.

Figura 3 - Fotomicrografia eletrônica de varredura de L. interrogans sorovar icterohaemorrhagie estirpe RGA 23

Figura 4 - Modelo da membrana celular de leptospiras indicando as principais estruturas descritas .

Figura 5 - Representação das três vias de ativação do sistema do complemento e a formação do MAC.

Figura 6 - Representação das cadeias $\alpha$ e $\beta$ da proteína C5 unidas entre si por uma ponte dissulfeto 31

Figura 7 - Estrutura de C5a e do MAC 32

Figura 8 - Receptores de C5a. 33

Figura 9 - Modelo de geração das linhagens congênicas 40

Figura 10 - Quantificação de leucócitos na circulação periférica de camundongos B6 $\mathrm{C}^{+}$e $\mathrm{A} / \mathrm{J} \mathrm{C5}$.

Figura 11 - Avaliação da função hepática de camundongos infectados com LPF . 50

Figura 12 - Concentração de citocinas no fígado dos camundongos infectados com LPF ..... 51 Figura 13 - Quantificação de leucócitos na circulação periférica de camundongos $\mathrm{B} 6 \mathrm{C}^{+}$e A/J C5 infectados com $10^{7}$ LPF. 53

Figura 14 - Avaliação da função hepática de camundongos infectados com $10^{7}$ LPF ........... 53

Figura 15 - Avaliação da função renal de camundongos infectados com $10^{7}$ LPF ................ 54

Figura 16 - Contagem de leucócitos presentes na circulação periférica de camundongos A/J e B6 infectados com $1,5 \times 10^{8} \mathrm{LPF}$. 56

Figura 17 - Porcentagem de linfócitos B na circulação periférica de camundongos infectados com $1,5 \times 10^{8} \mathrm{LPF}$ 57

Figura 18 - Porcentagem de linfócitos $\mathrm{T} \mathrm{CD}^{+}$e linfócitos $\mathrm{T} \mathrm{CD}^{+} \mathrm{CD} 25^{+}$na circulação de camundongos infectados com $1,5 \times 10^{8} \mathrm{LPF}$..... 58

Figura 19 - Porcentagem de linfócitos $\mathrm{T} \mathrm{CD}^{+}$e linfócitos $\mathrm{T} \mathrm{CD}^{+} \mathrm{CD} 25^{+}$na circulação de camundongos infectados com $1,5 \times 10^{8} \mathrm{LPF}$.... 59

Figura 20 - Desenvolvimento de esplenomegalia devido à infecção com 1,5 x $10^{8}$ LPF ....... 60 Figura 21 - Avaliação da função hepática de camundongos infectados com 1,5 x 10 ${ }^{8}$ LPF... 61 
Figura 22 - Avaliação da função renal de camundongos infectados com 1,5 x $10^{8}$ LPF.

Figura 23 - Concentração de citocinas no soro de camundongos infectados com $1,5 \times 10^{8} \mathrm{LPF}$.

Figura 24 - Concentração de citocinas no soro de camundongos infectados com $1,5 \times 10^{8} \mathrm{LPF}$.

Figura 25 - Concentração de TNF, IL-6 e IL-10 no fígado de camundongos infectados com $1,5 \times 10^{8} \mathrm{LPF}$. 66

Figura 26 - Concentração de IL-1ß, IL-12p40 e IL-12p70 no fígado de camundongos infectados com $1,5 \times 10^{8} \mathrm{LPF}$.....

Figura 27 - Concentração de TNF, IL-6 e IL-10 no rim de camundongos infectados com $1,5 \times 10^{8} \mathrm{LPF}$. 68

Figura 28 - Concentração de IL-1 $\beta$, IL-12p40 e IL-12p70 no rim de camundongos infectados com $1,5 \times 10^{8} \mathrm{LPF}$

Figura 29 - Concentração de TNF, IL-6 e IL-10 no pulmão de camundongos infectados com $1,5 \times 10^{8} \mathrm{LPF}$.

Figura 30 - Concentração de IL-1 $\beta$, IL-12p40 e IL-12p70 no pulmão de camundongos infectados com $1,5 \times 10^{8} \mathrm{LPF}$..... 72

Figura 31 - Lesões observadas no fígado de camundongos B6 infectados com $1,5 \times 10^{8} \mathrm{LPF}$ 74

Figura 32 - Lesões observadas no fígado de camundongos $\mathrm{A} / \mathrm{J}$ infectados com $1,5 \times 10^{8} \mathrm{LPF}$. 74

Figura 33 - Grau de lesão hepática dos camundongos infectados com 1,5 x $10^{8} \mathrm{LPF}$ 75 Figura 34 - Lesões pulmonares observadas nos camundongos B6 infectados com

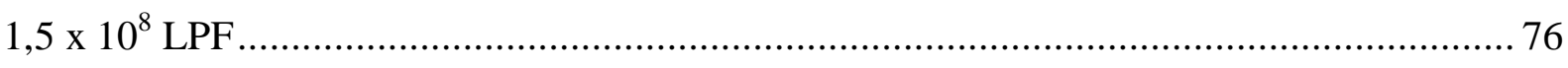

Figura 35 - Lesões pulmonares observadas nos camundongos A/J infectados com

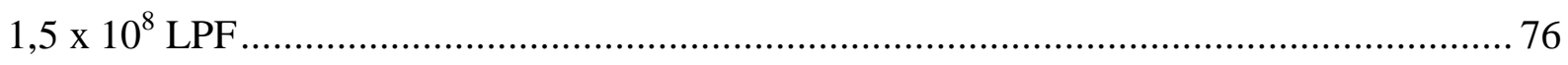

Figura 36 - Grau de lesão pulmonar dos camundongos infectados com 1,5 x $10^{8}$ LPF ......... 77 Figura 37 - Alterações observadas no baço de camundongos B6 infectados com $1,5 \times 10^{8} \mathrm{LPF}$. 78

Figura 38 - Alterações observadas no baço de camundongos A/J infectados com

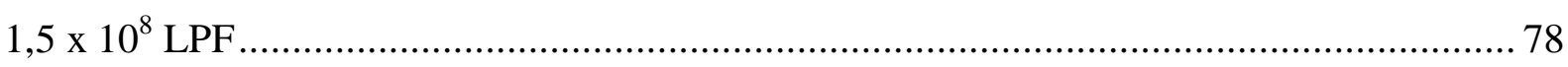

Figura 39 - Grau de alteração esplênica nos camundongos infectados com 1,5 x $10^{8}$ LPF..... 79

Figura 40 - Imagens do rim de camundongos B6 infectados com 1,5 x $10^{8} \mathrm{LPF}$ 80 
Figura 41 - Imagens do rim de camundongos A/J infectados com 1,5 x $10^{8} \mathrm{LPF}$. 80

Figura 42 - Detecção de LPF por imuno-histoquímica em diferentes órgãos de um camundongo $\mathrm{A} / \mathrm{J} \mathrm{C}^{-}$infectado com $1,5 \times 10^{8} \mathrm{LPF}$

Figura 43 - Detecção de LPF por imuno-histoquímica no fígado de camundongos B6 infectados com 1,5 x $10^{8} \mathrm{LPF}$.

Figura 44 - Detecção de LPF por imuno-histoquímica no fígado de camundongos A/J infectados com $1,5 \times 10^{8} \mathrm{LPF}$ 82 Figura 45 - Detecção de LPF por imuno-histoquímica no baço de camundongos B6 infectados com $1,5 \times 10^{8} \mathrm{LPF}$ 83

Figura 46 - Detecção de LPF por imuno-histoquímica no baço de camundongos A/J infectados com $1,5 \times 10^{8} \mathrm{LPF}$.

Figura 47 - Detecção de LPF por imuno-histoquímica no pulmão de camundongos B6 infectados com $1,5 \times 10^{8} \mathrm{LPF}$.... 84 Figura 48 - Detecção de LPF por imuno-histoquímica no pulmão de camundongos A/J infectados com $1,5 \times 10^{8} \mathrm{LPF}$. 84 Figura 49 - Detecção de LPF por imuno-histoquímica no rim de camundongos B6 infectados com $1,5 \times 10^{8} \mathrm{LPF}$

Figura 50 - Detecção de LPF por imuno-histoquímica no rim de camundongos A/J infectados com $1,5 \times 10^{8} \mathrm{LPF}$ 85 


\section{LISTA DE TABELAS}

Tabela 1 - Países e regiões com casos reportados de leptospirose 19

Tabela 2 - Células marcadas e anticorpos utilizados para sua detecção 44

Tabela 3 - Critérios para classificação histopatológica das alterações hepáticas no fígado de animais infectados com $1,5 \times 10^{8} \mathrm{LPF}$. 46

Tabela 4 - Critérios para classificação histopatológica das alterações pulmonares e esplênicas em animais infectados com $1,5 \times 10^{8} \mathrm{LPF}$ 46

Tabela 5 - Detecção de leptospiras no fígado e no rim de camundongos infectados com LPF 48

Tabela 6 - Detecção de leptospiras no fígado e no rim de camundongos infectados com $10^{7} \mathrm{LPF}$ 


\section{LISTA DE ABREVIATURAS E SIGLAS}

A -

A.B6-Hc -

ALT -

ANOVA -

APC -

APC-Cy7 -

AST -

B6 -

B6. A- $\mathrm{Hc}^{0}$ -

C1INH -

$\mathrm{C}_{24} \mathrm{H}_{39} \mathrm{NaO}_{4}$ -

C4BP -

C5adesArg -

C5aR -

C5L2 -

Carg 1/2 -

CBA -

CCL5 -

cDNA -

CXCL5 -

DAF -

DNA -

dNTP -

EDTA -

ELISA -

EMJH -

FB -

Fc -

FD -

FH -

FI -

FITC - adenosina

camundongo congênico A/J C5 normal

alanina aminotransferase

análise de variância

aloficocianina

conjugado de aloficocianina e corante de cianina

aspartato animotransferase

$\mathrm{C} 57 \mathrm{~B} 1 / 6$

camundongo congênico C57Bl/6 C5 deficiente

do inglês C1-inhibitor

deoxicolato de sódio

do inglês $\mathrm{C} 4 \mathrm{~b}$-binding protein

C5a que teve a arginina $\mathrm{C}$-terminal removida enzimaticamente receptor de $\mathrm{C} 5 \mathrm{a}$

receptor semelhante ao receptor de $\mathrm{C} 5 \mathrm{a}$

gene de resistência à Candida albicans - 1/2

do inglês cytometric bead array

do inglês chemokine (C-C motif) ligand 5

DNA complementar

do inglês chemokine (C-X-C motif) ligand 2

do inglês decay-accelerating factor

ácido desoxirribonucléico

desoxirribonucleotídeo trifosfato

do inglês ethylenediamine tetraacetic acid

do inglês enzyme linked immuno sorbent assay

do inglês Ellinghausen McCullough Johnson and Harris

Fator B

do inglês fragment crystallizable

Fator D

Fator $\mathrm{H}$

Fator I

isotiocianato de fluoresceína 


\begin{tabular}{|c|c|}
\hline $\mathrm{HCl}-$ & ácido clorídrico \\
\hline $\mathrm{HE}-$ & hematoxilina e eosina \\
\hline IFN- $\gamma-$ & interferon $\gamma$ \\
\hline $\operatorname{IgG}-$ & imunoglobulina $\mathrm{G}$ \\
\hline $\operatorname{IgM}-$ & imunoglobulina $\mathrm{M}$ \\
\hline $\mathrm{IH}-$ & imuno-histoquímica \\
\hline IL-1 $\beta$ - & interleucina $1 \beta$ \\
\hline IL-10 - & interleucina 10 \\
\hline IL-6 - & interleucina 6 \\
\hline IL-8 - & interleucina 8 \\
\hline IL-12 - & interleucina 12 \\
\hline $\mathrm{kDa}-$ & kilodalton \\
\hline $\mathrm{kb}-$ & kilobase \\
\hline $\mathrm{kg}-$ & Quilograma \\
\hline LPF - & $\begin{array}{l}\text { Leptospira interrogans sorovar Kennewicki estirpe Pomona } \\
\text { Fromm }\end{array}$ \\
\hline LPS - & lipopolissacarídeo \\
\hline L. biflexa - & Leptospira biflexa \\
\hline L. interrogans - & Leptospira interrogans \\
\hline LcpA - & do inglês leptospiral complement regulator-acquiring protein $\mathrm{A}$ \\
\hline Lig - A/B - & $\begin{array}{l}\text { do inglês High-molecular-weight leptospiral immunoglobulin- } \\
\text { like repeat } \mathrm{A} / \mathrm{B}\end{array}$ \\
\hline LRR - & do inglês leucine-rich repeat \\
\hline MAC - & complexo de ataque à membrana \\
\hline MASP $1 / 2 / 3-$ & $\begin{array}{l}\text { do inglês mannose-binding lectin associated serine protease - } \\
1 / 2 / 3\end{array}$ \\
\hline MBL - & do inglês mannose binding lectin \\
\hline MCP-1 - & do inglês monocyte chemotactic protein-1 \\
\hline $\mathrm{Mg}-$ & miligrama \\
\hline MIP-2 - & do inglês macrophage inflammatory protein 2 \\
\hline $\mathrm{mL}-$ & mililitro \\
\hline $\mathrm{MN}-$ & mononuclear \\
\hline $\mathrm{NaCl}-$ & cloreto de sódio \\
\hline
\end{tabular}




\begin{tabular}{|c|c|}
\hline $\mathrm{NaHCO}_{3}-$ & bicarbonato de sódio \\
\hline $\mathrm{Na}_{3} \mathrm{VO}_{4}-$ & orto vanadato de sódio \\
\hline $\mathrm{Na}_{4} \mathrm{P}_{2} \mathrm{O}_{7}-$ & pirofosfato de sódio \\
\hline $\mathrm{NH}_{4} \mathrm{Cl}-$ & cloreto de amônio \\
\hline NLRP3 - & do inglês NOD-like receptor family, pyrin domain containing 3 \\
\hline $\mathrm{NO}-$ & óxido nítrico \\
\hline PBS - & do inglês phosphate buffer saline \\
\hline PCR - & reação em cadeia da polimerase \\
\hline $\mathrm{PE}-$ & R-ficoeritrina \\
\hline PE-Cy7 - & conjugado de R-ficoeritrina e corante de cianina \\
\hline PercP - & complexo protéico peridinina-clorofila \\
\hline PMN - & polimorfonuclear \\
\hline RANTES - & $\begin{array}{l}\text { do inglês regulated on activation, normal } \mathrm{T} \text { cell expressed and } \\
\text { secreted }\end{array}$ \\
\hline RNA - & ácido ribonucleico \\
\hline RNAm - & ácido ribonucleico mensageiro \\
\hline RT-PCR - & do inglês real time polymerase chain reaction \\
\hline SDS - & dodecil sulfato de sódio \\
\hline SFB - & soro fetal bovino \\
\hline $\mathrm{T}-$ & timina \\
\hline TLR-2 - & receptor símile a toll - 2 \\
\hline TLR-4 - & receptor símile a toll - 4 \\
\hline TNF- $\alpha-$ & fator de necrose tumoral $-\alpha$ \\
\hline Tris - & Trizma base \\
\hline UFC - & unidade formadora de colônia \\
\hline$\mu g-$ & micrograma \\
\hline$\mu \mathrm{L}-$ & microlitro \\
\hline$\mu \mathrm{M}-$ & micromolar \\
\hline
\end{tabular}




\section{SUMÁRIO}

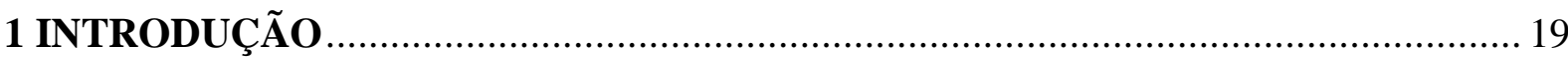

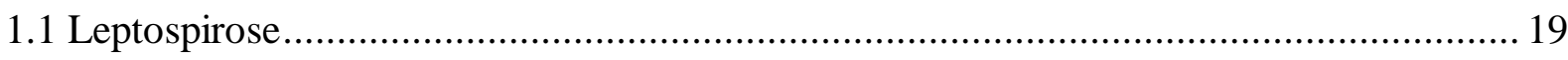

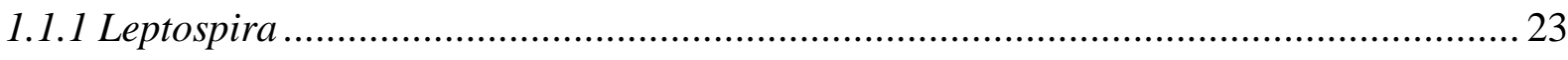

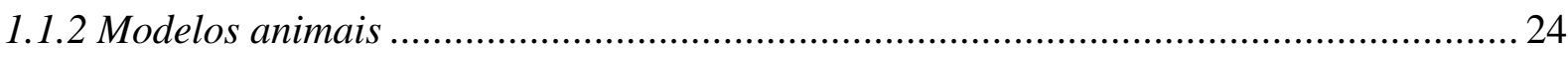

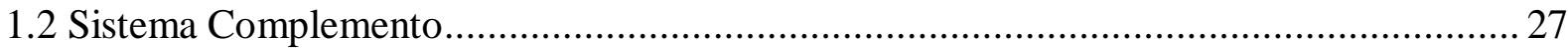

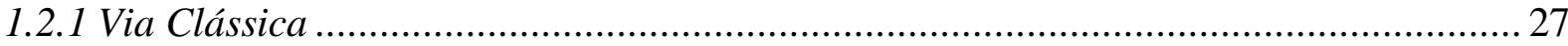

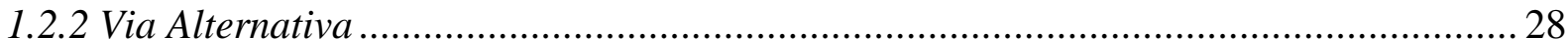

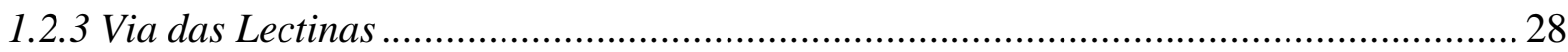

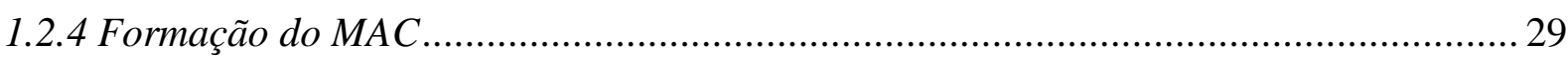

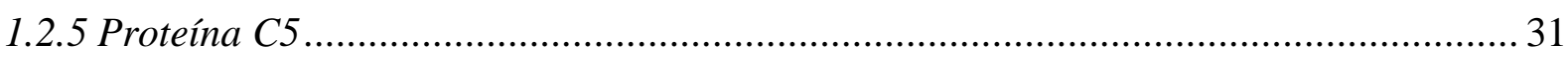

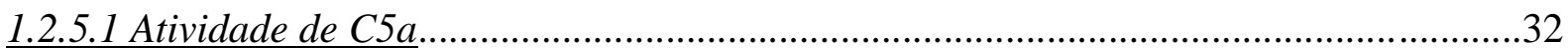

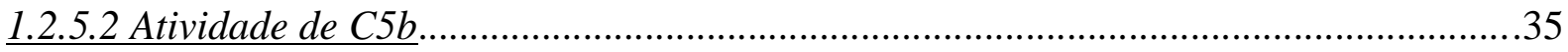

1.3 Importância do Sistema Complemento na leptospirose .............................................. 35

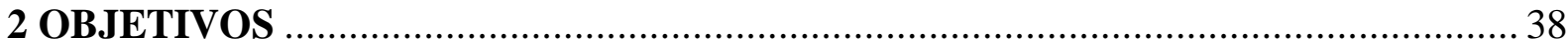

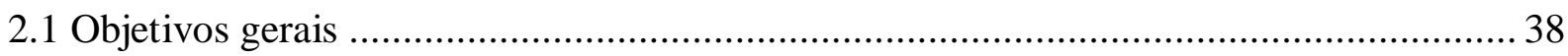

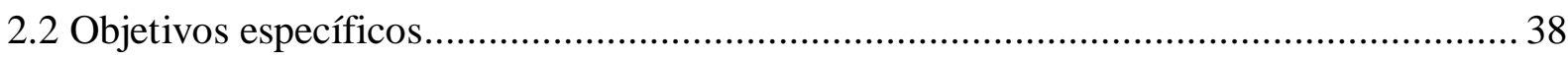

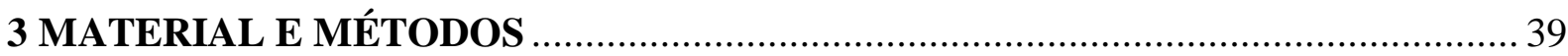

3.1 Obtenção e condições de cultivo de Leptospira interrogans ........................................... 39

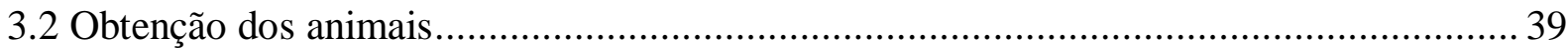

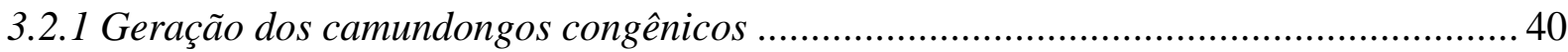

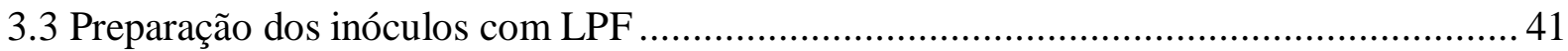

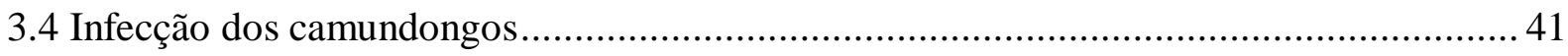

3.5 Eutanásia e coleta dos órgãos dos camundongos .................................................. 42

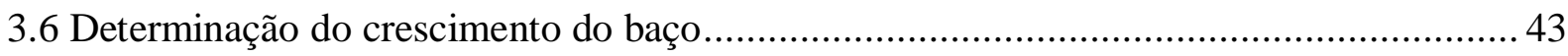

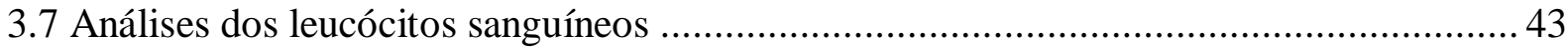

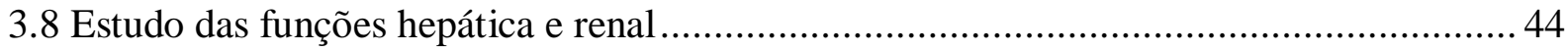

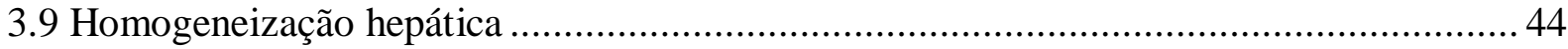

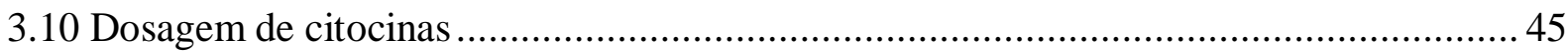

3.11 Análise histopatológica do fígado, rim, pulmão e baço ............................................ 45

3.12 Detecção de LPF por imuno-histoquímica ............................................................... 46

3.13 Recuperação de bactérias viáveis do fígado e rim ................................................... 47

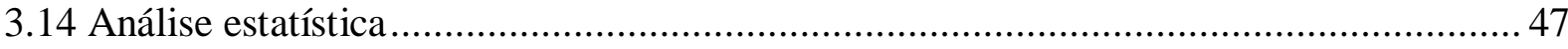


4.1 Resultados do modelo de infecção por três semanas ................................................. 48

4.1.1 Recuperação de leptospiras no fígado e no rim .......................................................... 48

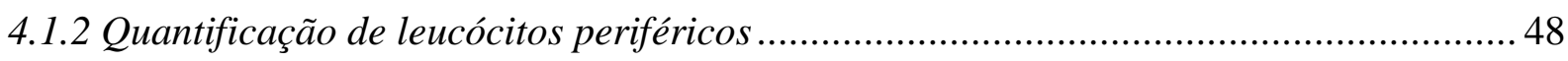

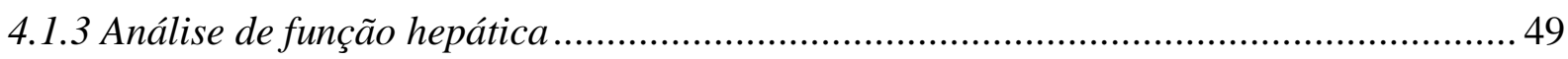

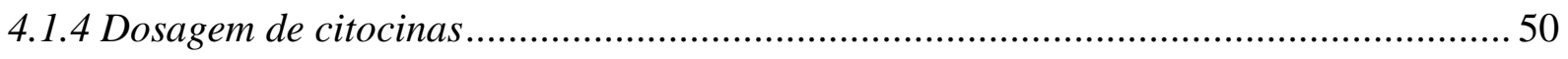

4.2 Resultados do modelo de infecção por seis dias com $10^{7}$ LPF..................................... 52

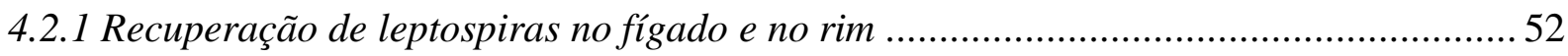

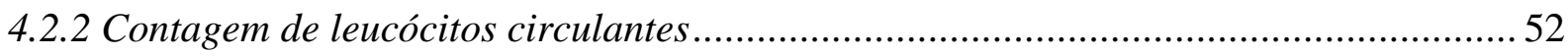

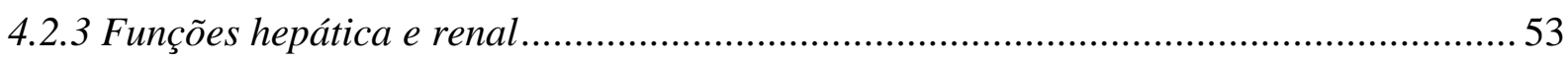

4.3 Resultados do modelo de infecção de seis dias com 1,5 x $10^{8}$ LPF...............................55

4.3.1 Quantificação de leucócitos na circulação periférica ................................................. 55

4.3.2 Desenvolvimento de esplenomegalia .................................................................... 59

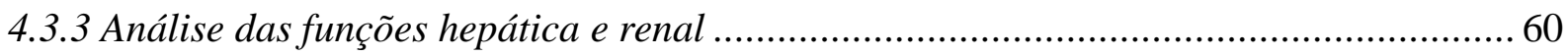

4.3.4 Concentração de citocinas no soro durante infecção com $1,5 \times 10^{8} \mathrm{LPF}$..................... 62

4.3.5 Concentração de citocinas no fígado durante infecção com $1,5 \times 10^{8} \mathrm{LPF}$.................. 65

4.3.6 Concentração de citocinas no rim durante infecção com $1,5 \times 10^{8} \mathrm{LPF}$...................... 67

4.3.7 Concentração de citocinas no pulmão durante infecção com $1,5 \times 10^{8} \mathrm{LPF}$................. 70

4.3.8 Análise histopatológica de camundongos infectados com $1,5 \times 10^{8} \mathrm{LPF}$..................... 73

4.3.9 Deteç̧ão de leptospiras por imuno-histoquímica em camundongos infectados com

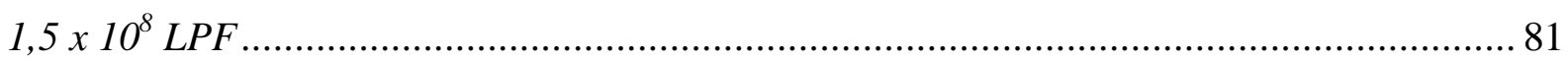

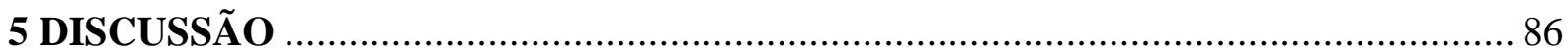

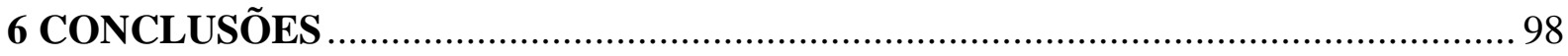

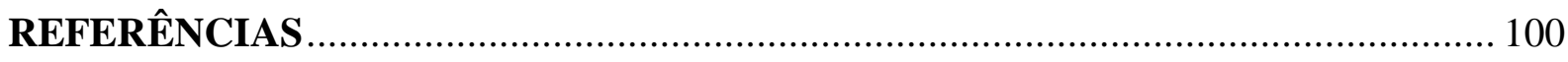

APÊNDICE - Publicações...................................................................................... 19 


\section{INTRODUÇÃO}

\subsection{Leptospirose}

Descrita no final do século XIX por Adolph Weil (Faine et al., 1999), a leptospirose é uma zoonose de alcance mundial (Organização Mundial da Saúde - OMS, 1999) que atinge pessoas residentes principalmente em países subdesenvolvidos situados em regiões tropicais e de clima ameno, infectando aproximadamente 500.000 pessoas todos os anos (Tabela 1) (Faine et al., 1999; Lau et al., 2010; Levett, 2001).

O contato com água, alimentos ou outras substâncias contaminados pela urina de organismos portadores de bactérias patogênicas do gênero Leptospira permite que seres humanos e animais de importância econômica contraiam acidentalmente leptospirose, fato que ocorre principalmente durante os períodos de chuva intensa e em locais de clima ameno com condições sanitárias precárias (Figura 1) (Adler, Moctezuma, 2010; Bharti et al., 2003; Fraga et al., 2011).

Tabela 1 - Países e regiões com casos reportados de leptospirose

\begin{tabular}{cc}
\hline País ou região & $\begin{array}{c}\text { Incidência } \\
\mathbf{1 0 0 . 0 0 0 / a n o}\end{array}$ \\
\cline { 2 - 3 } Vanuatu & 40 \\
Antilhas, Guiana & 23 \\
Kerala, Índia & 11,4 \\
China & 7,1 \\
Nova Caledônia, França & $2,1-30$ \\
Tailândia & $4,1-40$ \\
Siri Lanka & 11 \\
Polinésia francesa & 11 \\
Ilhas Açores, Portugal & 11 \\
Camboja & 7,7 \\
Costa Rica & 6,7 \\
Havaí & 3,3 \\
Nova Zelândia & 2,8 \\
Cuba & 2,5 \\
Croácia & 1,8 \\
Brasil & 1,7 \\
Argentina & 1,0 \\
Austrália & 0,52 \\
Itália & 0,13 \\
Alemanha & 0,06 \\
Israel & 0,05 \\
\hline
\end{tabular}

Fonte: Adaptada de Lau et al., (2010) 
Figura 1 - Ciclo de infecção da leptospirose

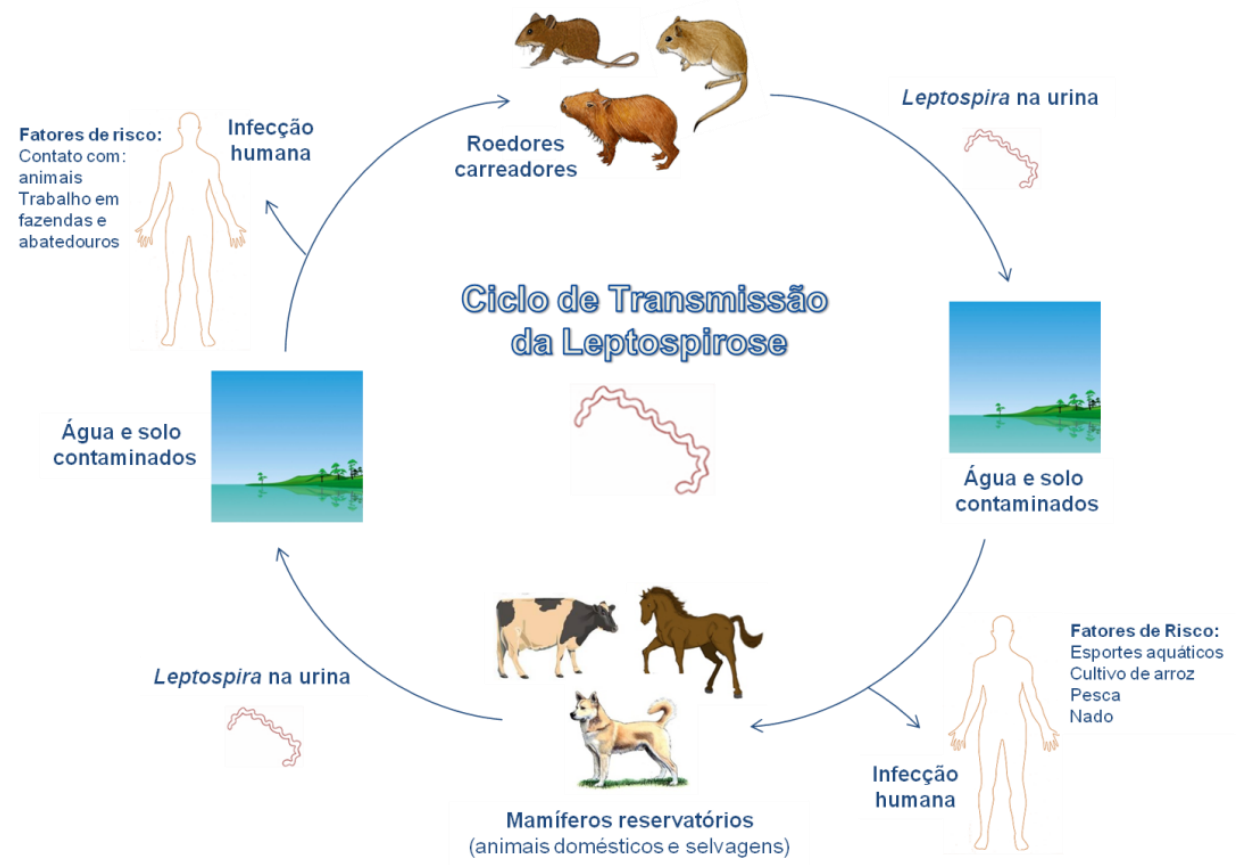

Mamíferos selvagens e domesticados podem atuar como reservatórios da L. interrogans, liberando constantemente a bactéria através da urina e contaminando a água e o solo. O contato de organismos saudáveis, incluindo seres humanos, com a água e solo contaminados pode iniciar um novo ciclo de infecção. (Figura cedida pela doutoranda Tatiana Rodrigues Fraga).

Causada por diferentes espécies de leptospiras, esta infecção, antes considerada predominante em profissionais como mineradores, agricultores e veterinários em contato direto com locais e animais potencialmente contaminados, também atinge cidadãos residentes em regiões com deficiência no saneamento básico e praticantes de atividades de recreação esportiva em lagoas, com maior frequência durante as estações mais chuvosas (Adler, Moctezuma et al., 2010; Bharti et al., 2003).

Inicialmente caracterizada por esplenomegalia, icterícia e nefrite (Craig, 2010 apud Weil, 1886), o que levou essa doença a ser chamada de síndrome de Weil, a leptospirose exibe um quadro clínico bastante variável dentro da população (Levett, 2001), podendo permanecer assintomática em diversos indivíduos dependendo do tipo de sorovar e do número de bactérias infectantes. Quando se manifesta, o diagnóstico de leptospirose pode ser dificultado devido ao surgimento de sintomas menos graves e frequentemente comuns a outras doenças, como febre e dores musculares, os quais podem ser sucedidos por graves lesões no fígado, rins e pulmões, sendo por isso considerada uma doença com desenvolvimento bifásico, sendo a primeira fase mais amena e a segunda mais intensa (Ko et al., 2009; Levett, 2001; Picardeau, 2013). 
A primeira semana após o período de incubação da infecção, também chamada de fase aguda ou anictérica, é caracterizada pela presença desta bactéria principalmente no sangue do indivíduo e por episódios frequentes de febre. Essa fase da infecção também está associada à presença de dores retro-orbitais e fotofobia, ao desenvolvimento de hemorragia subconjuntival, a qual tende a desaparecer rapidamente, calafrios, mialgia principalmente na região lombar da coluna, coxas e panturrilhas e, em alguns casos, ao desenvolvimento de erupções cutâneas. Esses sintomas tendem a cessar coincidindo com o aumento da concentração de anticorpos específicos no organismo e não representam grandes riscos para o indivíduo, resultando em uma baixa taxa de mortalidade durante esse período (Figura 2, Ko et al., 2009; Levett, 2001).

Figura 2 - Modelo do desenvolvimento clínico da leptospirose com indicação de sintomas presentes nos estágios inicial e tardio da infecção

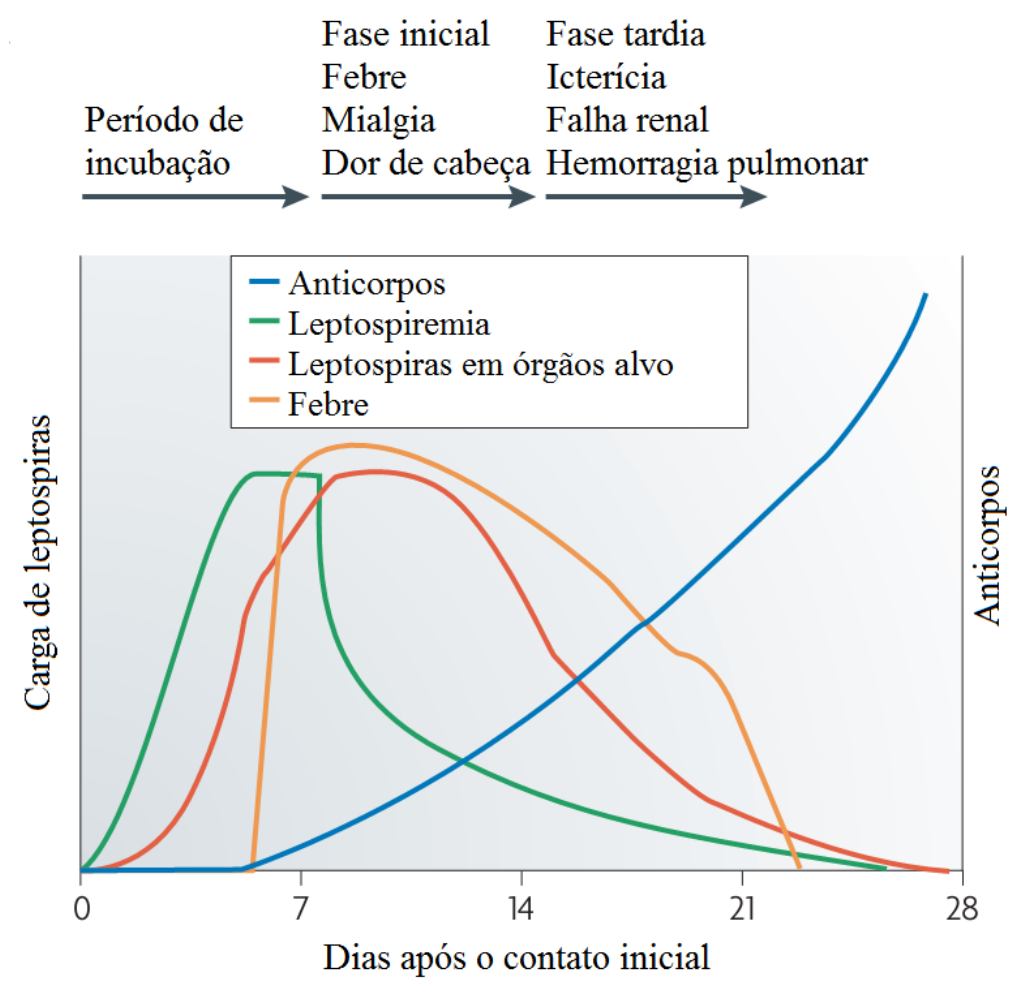

As linhas representam a produção de anticorpos (azul), quantidade de leptospiras no organismo (verde), órgãos afetados pela infecção (vermelho) e o período onde ocorrem os episódios de febre (laranja). A carga bacteriana no sangue do indivíduo permanece alta durante os primeiros dias da infecção, diminuindo concomitantemente ao aumento do número de leptospiras nos órgãos colonizados por essa bactéria. Episódios de febre são comuns no início da infecção, tornando-se menos frequentes durante a progressão da doença. São detectados anticorpos específicos contra a leptospira a partir da primeira semana de infecção, os quais podem ser encontrados em grandes concentrações em fases mais tardias da doença.

Fonte: Adaptada de Ko et al., (2009) 
A fase crônica ou ictérica da doença corresponde ao momento em que a leptospira passa a ser encontrada em menor quantidade no sangue e inicia a colonização de órgãos importantes para a leptospirose, como o fígado e os rins, sendo então continuamente eliminada através da urina por períodos que variam de algumas semanas a vários meses. É durante a fase ictérica que surgem as complicações que resultam na alta taxa de mortalidade entre os pacientes diagnosticados com leptospirose, que é de aproximadamente $10 \%$ dos casos. Além do desenvolvimento de falha hepática e renal, vários pacientes apresentam icterícia, que está relacionada à perda da capacidade de metabolização da bilirrubina pelo fígado, levando ao seu acúmulo no organismo, surgimento de uveíte, miocardite, pancreatite necrótica e queda do número de plaquetas circulantes. Também tem sido relatado o aumento do número de casos de hemorragia pulmonar em diversos países, condição que reduz a probabilidade de recuperação completa do paciente (Faine et al., 1999; Levett, 2001; LorenzoMorales, 2012; Marotto et al., 1999; OMS, 1999; Sarkar, et al., 2002).

O diagnóstico dos pacientes com suspeita de infecção pode ser feito por diferentes técnicas, as quais buscam identificar diretamente a presença da leptospira no organismo ou de anticorpos específicos contra ela, sendo cada uma delas adequada para momentos específicos da doença. Por causa da leptospiremia durante os primeiros dias após o surgimento dos sintomas, é possível observar essas bactérias em amostras de sangue do paciente por microscopia óptica sob campo escuro. Caso a leptospiremia seja pouco intensa ou o tempo entre o surgimento dos sintomas e a realização dos exames seja longo e, por isso, poucas bactérias sejam encontradas na circulação, é recomendável a realização de reação em cadeia empregando DNA polimerase (PCR) e PCR em tempo real (RT-PCR) para quantificação e determinação da espécie infectante (Bharti et al., 2003; Lau et al., 2010; Picardeau, 2013; Vijayachari et al., 2008).

A detecção de anticorpos circulantes anti-leptospira permite a identificação do sorogrupo e é recomendada a partir do $8^{\circ}$ dia do início dos sintomas. Após essa data já é possível encontrar títulos altos de anticorpos aglutinantes na circulação, os quais podem ser identificados tanto por teste de aglutinação de leptospiras quanto por ELISA (Bharti et al., 2003; Lau et al., 2010; Vijayachari et al., 2008).

Diversos sorovares patogênicos do gênero Leptospira, ordem Spirochaetales (Faine et al., 1999) podem naturalmente ser encontrados em diferentes espécies de mamíferos. Alguns desses animais, como roedores em geral e cães domésticos, mantêm contato constante com humanos, facilitando a transmissão de leptospiras dentro da população (Guerreiro et al., 2001; 
Levett, 2001). Ao contrário da espécie humana, alguns roedores são animais considerados resistentes à infecção, não desenvolvendo sinais clínicos da doença, embora tenham seus rins colonizados pelas leptospiras e sejam capazes de eliminá-las pela sua urina por longos períodos de tempo (Faine et al., 1999).

\subsubsection{Leptospira}

Descobertas no início do século XX (Kobayashi 2001 apud Inada e Ido, 1915), as bactérias causadoras da leptospirose fazem parte do gênero Leptospira, que contém espécies saprófitas como a L. biflexa, incapaz de se estabelecer em nosso organismo, e patogênicas como a L. interrogans (Adler, Moctezuma, 2010). Essas bactérias possuem formato fino, espiralado e comprimento em torno de $10 \mu \mathrm{M}$, além de ser comum observar uma típica curvatura em suas extremidades (Figura 3, Fraga et al., 2011; Ko et al., 2009; Levett, 2001).

Figura 3 - Fotomicrografia eletrônica de varredura de L. interrogans sorovar icterohaemorrhagie estirpe RGA

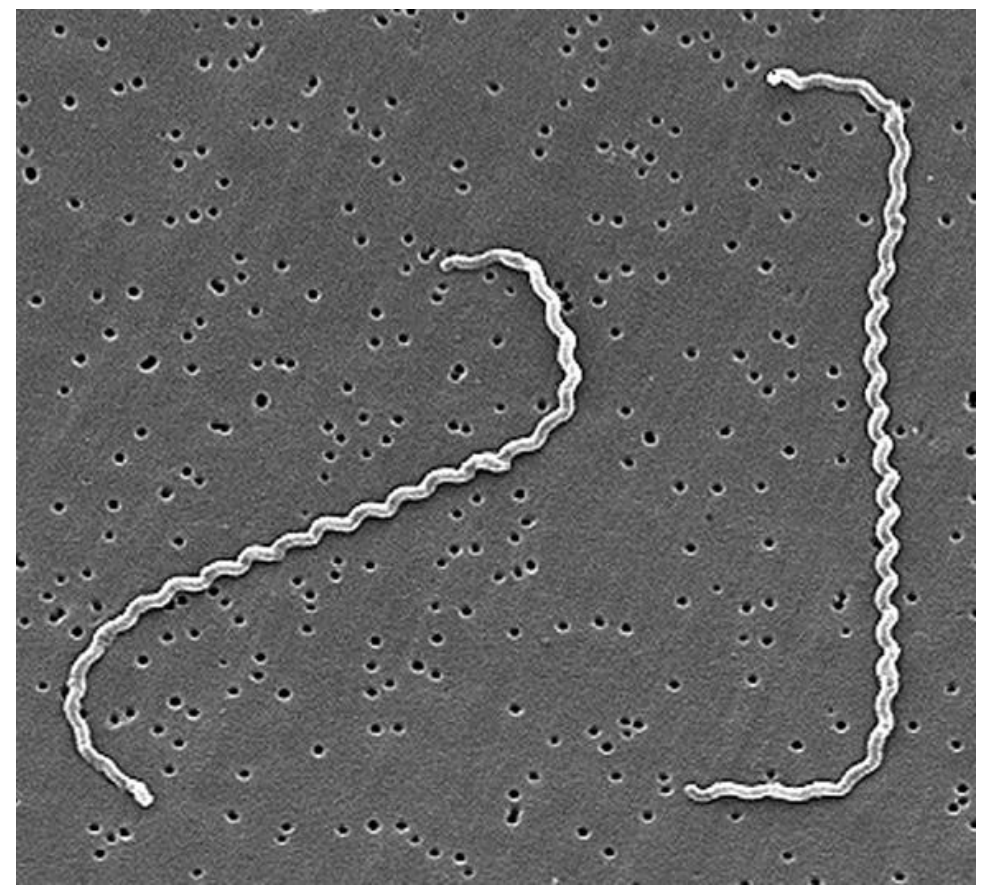

Fonte: Levett (2001)

Essas bactérias possuem uma estrutura membranar semelhante à de bactérias Gramnegativas, com a membrana celular sendo envolvida por uma parede celular, composta de peptideoglicanos, e uma membrana externa, rica em proteínas e lipopolissacarídeos (LPS), os 
quais são menos tóxicos em relação a moléculas análogas de demais organismos presentes nesse grupo (Figura 4, Ko et al., 2009).

Apesar da menor toxicidade, as moléculas de LPS são bastante importantes, pois as variações encontradas nestas moléculas de diferentes leptospiras fornece um importante instrumento para sua classificação, permitindo agrupá-las em mais de 200 sorovares (Adler, Moctezuma, 2010; Fraga et al., 2011).

Figura 4 - Modelo da membrana celular de leptospiras indicando as principais estruturas descritas

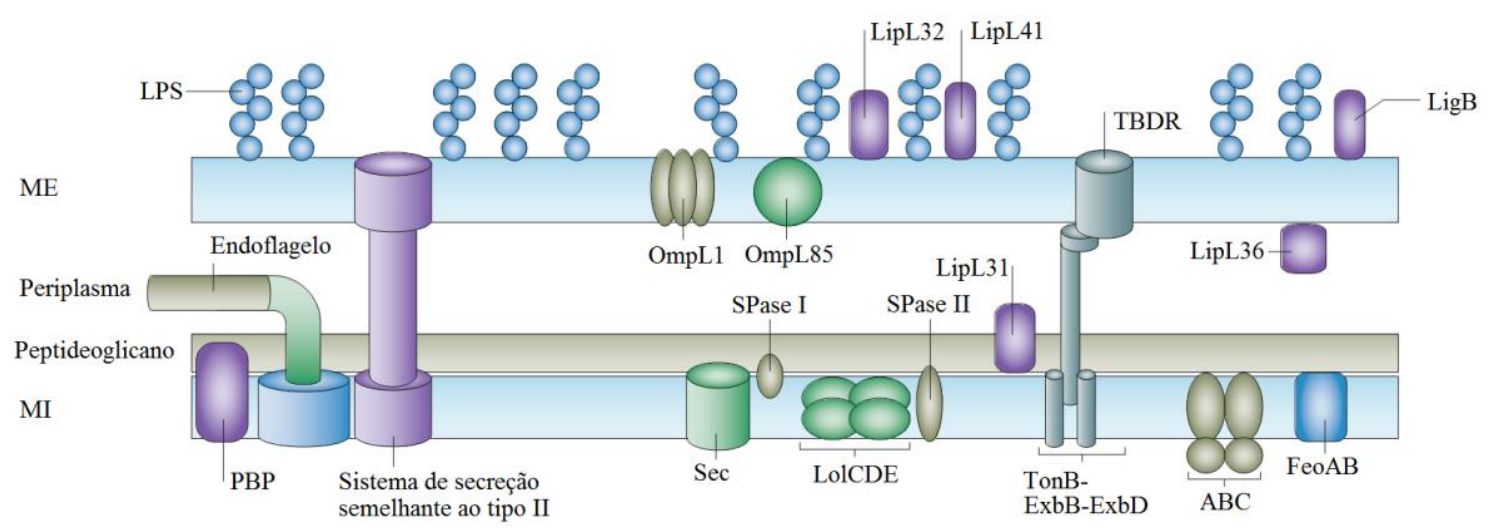

Há uma membrana interna (MI) onde estruturas como flagelos ficam ancorados, uma fina parede de peptideoglicano que está associado à essa membrana interna, o espaço periplasmático, onde estão localizados os flagelos das leptospiras, e a membrana externa (ME), que contém moléculas de lipopolissacarídeos (LPS) e diferentes proteínas em sua superfície. PBP: proteína ligadora de penicilina; Sec: sistema de secreção; LolCDE: transportador formado por LolC, LolD e LolE; ABC: transportador ABC;SPase: peptidase sinal da lipoproteína; LipL31: lipoproteína LipL31; TBDRs: Receptores dependentes de TonB; TonB-ExbB-ExbD: complexo transdutor de energia de TonB-ExbB-ExbD; FeoAB: transportador de ferro tipo FeoA-FeoB; OmpL1: porina transmembrana presente na membrana externa L1; LipL32: lipoproteína LipL32; LipL36: lipoproteína LipL36; LipL41: lipoproteína LipL41; LigB: proteína B de leptospira com domínios encontrados na superfamília de imunoglobulinas.

Fonte: Adaptada de Ko et al., (2009)

\subsubsection{Modelos animais}

Buscando o melhor entendimento dos fatores que podem conferir resistência contra as leptospiras, diversos autores têm empregado diferentes linhagens de camundongos em seus estudos avaliando alterações protéicas e estruturais nos órgãos mais atingidos pela doença e no sangue, bem como o efeito de cada componente do sistema imune no controle da infecção.

Tanto trabalhos mais antigos quanto os mais recentes mostram que a imunidade humoral tem um papel relevante no controle e proteção contra a leptospirose. Camundongos normalmente resistentes à Leptospira podem se tornar susceptíveis se tratados com ciclofosfamida, uma substância imunossupressora que inibe a atividade de linfócitos B e 
impede a produção de anticorpos, afetando consequentemente a imunidade humoral (Adler, Faine, 1976; 1977). No entanto, caso esses camundongos já possuam anticorpos contra as leptospiras, ou recebam um transplante de células do baço no período entre a aplicação da ciclofosfamida e a inoculação das leptospiras, não desenvolvem leptospirose. Esses camundongos previamente imunizados contra leptospiras ou que receberam transplantes de baço apresentam anticorpos em seu soro, uma informação importante sobre a relevância do sistema imune humoral, especialmente dos linfócitos B, na cura dessa infecção. Esses resultados foram corroborados por estudos recentes, onde depletaram linfócitos B ou linfócitos T de camundongos (Chassin et al., 2009). Nesse caso, os animais infectados que não possuíam linfócitos $\mathrm{B}$ morriam, mostrando a grande importância destas células e, portanto, dos anticorpos, para a resistência contra essa doença. Embora a ausência de linfócitos T não afetasse a sobrevida dos camundongos infectados, os autores sugeriram que essas células devem desempenhar um papel importante na proteção de diferentes órgãos, especialmente dos rins, contra eventuais danos estruturais, como nefrite no túbulo intersticial, sendo encontradas em quantidades elevadas junto com a produção da isoforma induzida da enzima óxido nítrico sintase (Chassin et al., 2009).

Mesmo linhagens de camundongos consideradas resistentes à infecção por leptospiras (C57B1/6, por exemplo) sofrem lesões em órgãos como o fígado e o rim, embora esses danos ocorram em menor intensidade do que o observado em linhagens susceptíveis $(\mathrm{C} 3 \mathrm{H} / \mathrm{HeJ}$, por exemplo) (da Silva et al., 2009). Contudo, mesmo linhagens de camundongos naturalmente susceptíveis a leptospiras podem não apresentar lesões pulmonares quando infectadas com doses consideradas letais para hamsters, sendo necessário aplicar inóculos com grandes quantidades de leptospiras para induzir danos nesse órgão (Marinho et al., 2009; Nally et al., 2005; Viriyakosol et al., 2006). Entre os danos observados no tecido hepático, há desestruturação do padrão de organização das células, pontos de necrose, infiltrados celulares e aumento do número de células de Küppfer. Nos rins ocorrem danos nos túbulos renais, causando nefrite, e acúmulo de infiltrados inflamatórios (Nally et al., 2005; Santos et al., 2010). Outra característica importante do desenvolvimento da leptospirose nos camundongos é que, apesar de níveis detectáveis de anticorpos sanguíneos anti-leptospiras circulantes serem encontrados três dias após a infecção (Adler, Faine, 1976), leptospiras vivas são observadas no fígado e nos rins mesmo até quatro semanas após inoculação (da Silva et al., 2009; Santos et al., 2010). 
Com relação à resposta inflamatória, os níveis de diferentes quimiocinas próinflamatórias se aproximam dos níveis basais pré-infecção em até duas semanas nos camundongos resistentes à leptospirose, em contraposição com os camundongos susceptíveis, onde, por exemplo, o nível da proteína quimiotática de monócitos-1 (MCP-1) permanece alto no soro, rins e pulmão até o período da morte, mantendo a resposta inflamatória em níveis acima do normal, o que poderia ser prejudicial para o hospedeiro (da Silva et al., 2009).

Sabendo da importância do receptor símile a Toll (TLR) 4 no reconhecimento de LPS de bactérias gram-negativas (Poltorak et al., 1998), diferentes pesquisadores buscaram observar sua importância em modelos murinos na infecção por leptospiras. Assim como observado em estudos com outras bactérias gram-negativas, camundongos da linhagem C3H/HeJ, que não expressam TLR-4, também são susceptíveis à Leptospira. Camundongos nocaute para o gene responsável pela expressão do TLR-4 também são mais susceptíveis à infecção por leptospiras patogênicas, o que está de acordo com o que seria esperado devido à importância desse receptor no reconhecimento de LPS (Chassin et al., 2009; Poltorak et al., 1998; Viriyakosol et al., 2006).

Assim como TLR-4, a molécula TLR-2 também reconhece LPS de leptospiras em camundongos, sendo que na sua ausência embora as células do sistema imune dos camundongos sejam capazes de reconhecer LPS pelo TLR-4 como citado anteriormente, há uma redução da intensidade da resposta imunológica contra estas bactérias (Chassin et al., 2009; Werts et al., 2001).

Da mesma forma que camundongos nocautes para tlr4 são susceptíveis à leptospirose, animais duplo-nocautes para $t l r 2$ e $t l r 4$ desenvolvem o mesmo quadro clínico de leptospirose aguda observada em humanos, como falha das funções hepática e renal e hemorragia pulmonar. Nesses camundongos há menor controle da infecção por leptospirose, com maior número de bactérias viáveis em seus órgãos do que o observado em camundongos normais para essas duas proteínas. A ausência desses dois receptores também alterou o padrão de produção de alguns fatores pró-inflamatórios em alguns órgãos, como a redução da expressão de interferon (IFN)- $\gamma$ no fígado, e aumento da expressão de interleucina (IL) 6 , fator de necrose tumoral (TNF - do inglês Tumor necrosis factor)- $\alpha$, CCL5 (proteína regulada na ativação, normalmente expressada e secretada por células T - RANTES) e CXCL2 (proteína inflamatória de macrófagos 2 - MIP-2) no fígado e nos rins (Chassin et al., 2009). 


\subsection{Sistema Complemento}

O Sistema Complemento participa efetivamente da imunidade inata e adquirida, sendo composto por mais de 30 proteínas que podem ser encontradas no plasma e na superfície das células do organismo (Walport, 2001). Proteínas como C1q, lectinas ligadoras de manose (MBL) e C3 desencadeiam a ativação de cascatas enzimáticas que geram produtos responsáveis tanto pela eliminação da partícula alvo quanto pela estimulação de diferentes tipos celulares que auxiliarão esse processo, enquanto proteínas reguladoras como a proteína inibidora de $\mathrm{C} 1$ esterase $(\mathrm{C} 1 \mathrm{INH})$, a proteína ligadora de C4b (C4BP) e o Fator I (FI) modulam a atividade do Sistema Complemento, mantendo sua ativação sob controle e impedindo seu consumo excessivo e lesão de tecidos saudáveis (Zipfel, Skerka, 2009).

Descoberto no final do século XIX como uma substância termo-sensível presente no soro que aumentava a eliminação de bactérias por anticorpos (Walport, 2001), esse sistema é importante para a manutenção da homeostase no organismo, participando da eliminação de células apoptóticas e de complexos imunes e estimulando a angiogênese e a reparação tecidual, além de interagir com outros sistemas de cascatas enzimáticas, como o sistema da coagulação. Além dessas funções, o Sistema Complemento é importante para resposta contra infecções, promovendo a opsonização de patógenos e atraindo fagócitos para o local infectado e pode ser dividido em três vias distintas: Via Clássica, Via Alternativa e Via das Lectinas (Figura 5).

\subsubsection{Via Clássica}

A Via Clássica foi a primeira a ser descrita, sendo ativada principalmente pela interação entre a proteína $\mathrm{C} 1 \mathrm{q}$ do complexo $\mathrm{C} 1$ e a porção $\mathrm{Fc}$ de anticorpos $\mathrm{IgG}$ (domínio $\mathrm{CH}_{2}$ ) ou IgM (domínio $\mathrm{CH}_{3}$ ) ligados a antígenos. Dessa forma, a Via Clássica atua como um elo entre a imunidade adaptativa mediada por anticorpos, com a imunidade inata. Além de C1q, o complexo $\mathrm{C} 1$ é formado por dois dímeros de $\mathrm{C} 1 \mathrm{r}$ e $\mathrm{C} 1 \mathrm{~s}$, que, quando ativados, resultam na posterior clivagem de $\mathrm{C} 4$ e de $\mathrm{C} 2$. A ligação de $\mathrm{C} 1 \mathrm{q}$ a pelo menos duas moléculas de anticorpo IgG ou uma molécula de IgM especificamente ligadas a antígenos causa a ativação da subunidade $\mathrm{C} 1 \mathrm{r}$, que por sua vez cliva a subunidade $\mathrm{C} 1 \mathrm{~s}$, tornando-a ativa. $\mathrm{C} 1 \mathrm{~s}$ irá então clivar C4 em C4a e C4b, podendo o fragmento C4b ser depositado covalentemente sobre a superfície do antígeno. Uma vez fixado, C4b interage com $\mathrm{C} 2$, permitindo que essa proteína também seja clivada por $\mathrm{C} 1 \mathrm{~s}$ e dê origem aos fragmentos $\mathrm{C} 2 \mathrm{a}$, que permanece ligado 
a $\mathrm{C} 4 \mathrm{~b}$, e $\mathrm{C} 2 \mathrm{~b}$. O complexo $\mathrm{C} 4 \mathrm{bC} 2 \mathrm{a}$ passa a ter atividade de $\mathrm{C} 3$ convertase, clivando moléculas de C3 em C3a e C3b, sendo por essa razão conhecido como C3 convertase.

Assim como $\mathrm{C} 4 \mathrm{~b}$, os fragmentos $\mathrm{C} 3 \mathrm{~b}$ podem se ligar covalentemente à superfície aceptora, podendo agir como opsoninas, originar novos complexos com atividade de C3 convertase ou interagir com os complexos $\mathrm{C} 4 \mathrm{bC} 2 \mathrm{a}$ já existentes, formando o complexo C4b2a3b, que passa a ter atividade de C5 convertase, clivando C5 em C5a e C5b e iniciando a formação do complexo de ataque à membrana (MAC, do inglês membrane attack complex).

\subsubsection{Via Alternativa}

Considerada a mais antiga na escala evolutiva, a Via Alternativa é inicialmente ativada pela hidrólise espontânea da ligação tiól-ester localizada na cadeia $\alpha$ da proteína $C 3$, que passa a ser chamada $\mathrm{C} 3\left(\mathrm{H}_{2} \mathrm{O}\right)$. $\mathrm{C} 3\left(\mathrm{H}_{2} \mathrm{O}\right)$ pode interagir com a molécula de Fator $\mathrm{B}(\mathrm{FB})$, permitindo agora a clivagem de FB pelo Fator D (FD), gerando os fragmentos $\mathrm{Bb}$, que permanece ligado a $\mathrm{C} 3 \mathrm{~b}$ e origina o complexo $\mathrm{C} 3\left(\mathrm{H}_{2} \mathrm{O}\right) \mathrm{Bb}$, liberando o fragmento $\mathrm{Ba}$. $\mathrm{O}$ complexo $\mathrm{C} 3\left(\mathrm{H}_{2} \mathrm{O}\right) \mathrm{Bb}$ é então estabilizado ao interagir com properdina, podendo desempenhar sua atividade de C3 conversase, sendo por esse motivo chamado de primeira C3 convertase da Via Alternativa. Assim como a C3 convertase da Via Clássica, $\mathrm{C} 3\left(\mathrm{H}_{2} \mathrm{O}\right) \mathrm{Bb}$ clivará C3 em C3a e C3b. C3b pode interagir com FB, que agora complexado poderá ser clivado igualmente por $\mathrm{FD}$ em $\mathrm{Bb}$ e $\mathrm{Ba}$. O complexo $\mathrm{C} 3 \mathrm{bBb}$ é estabilizado pela properdina e é capaz de clivar enzimaticamente $\mathrm{C} 3$, sendo chamado de segunda C3 convertase da Via Alternativa. C3b também poderá interagir com os complexos C3 convertases, originando $\mathrm{C} 3\left(\mathrm{H}_{2} \mathrm{O}\right) \mathrm{BbC} 3 \mathrm{~b}$ e $\mathrm{C} 3 \mathrm{bBbC} 3 \mathrm{~b}$, ambas com atividade de $\mathrm{C} 5$ convertase.

\subsubsection{Via das Lectinas}

Última via a ser descrita, a Via das Lectinas é ativada após a interação de carboidratos presentes em proteínas e polissacarídeos da superfície de células de microorganismos com lectinas como a proteína ligadora de manose (MBL, do inglês mannose binding lectin) ou com ficolinas presentes no plasma. Tanto a MBL quanto as ficolinas são estruturalmente semelhantes a C1q e interagem com as serino-proteases associadas à MBL (MASP, do inglês MBL-associated serine proteases; MASP-1, MASP-2 e MASP-3). Uma vez que a MBL se liga à manose, a proteína MASP-2 tem sua estrutura alterada e torna-se ativa, sendo capaz de, assim como C1s, clivar as moléculas de $\mathrm{C} 4$ em $\mathrm{C} 4 \mathrm{a}$ e $\mathrm{C} 4 \mathrm{~b}$ e de $\mathrm{C} 2$ em $\mathrm{C} 2 \mathrm{a}$ e $\mathrm{C} 2 \mathrm{~b}$. Como 
descrito para a Via Clássica, C4b pode se ligar à superfície sobre a qual houve ativação do Sistema Complemento, podendo interagir com C2. A molécula de C2 será então clivada pela MASP-2, permanecendo o fragmento $\mathrm{C} 2 \mathrm{a}$ unido ao $\mathrm{C} 4 \mathrm{~b}$, formando o complexo $\mathrm{C} 4 \mathrm{~b} 2 \mathrm{a}$, uma enzima com atividade de C3 convertase também gerada na Via Clássica.

\subsubsection{Formação do MAC}

A formação dos complexos C3bBb3b (Via Alternativa) e C4b2a3b (Via Clássica e Via das Lectinas) resulta na clivagem da proteína C5 em C5a, com importantes funções para a resposta inflamatória e $\mathrm{C} 5 \mathrm{~b}$, que iniciará a formação do MAC.

C5b interage com C6 e na sequência C6 se liga a C7 ainda na fase aquosa, formando o complexo C5b67, capaz de interagir com membranas celulares. A interação desse complexo com C8 forma o complexo C5b678, permitindo a interação com várias moléculas de C9, formando o complexo C5b6789 $(\mathrm{n})$, também chamado de MAC. Devido à formação de um canal transmembrana, o MAC é responsável pela formação de poros na membrana da célula atacada, desregulando seu balanço osmótico e levando-a a lise. 
Figura 5 - Representação das três vias de ativação do sistema do complemento e a formação do MAC

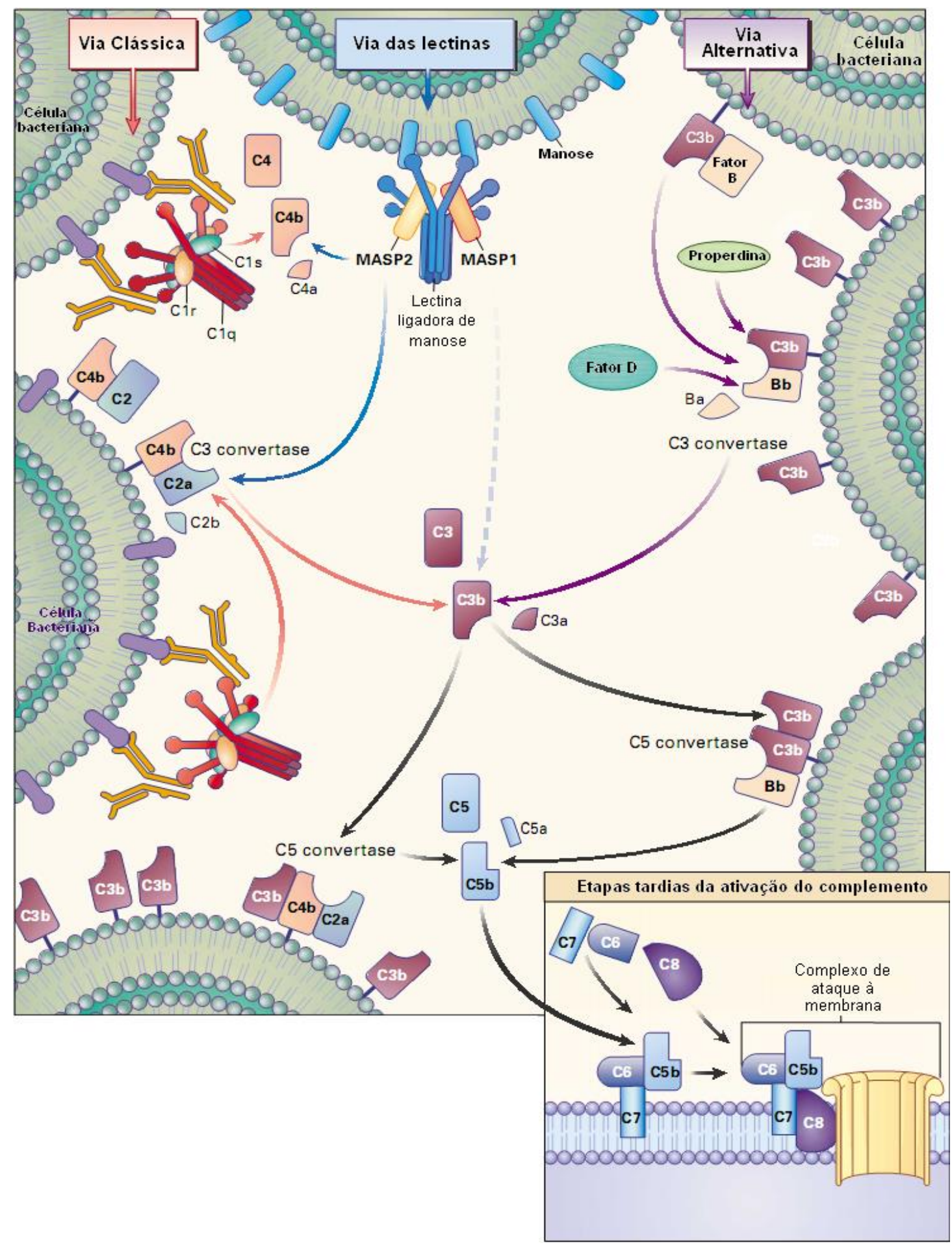

A Via Clássica (à esquerda) é geralmente ativada após a interação do complexo C1 com a região Fc de imunoglobulinas do tipo IgG e IgM ligadas especificamente a antígenos. A Via Alternativa (à direita) é ativada após a ligação covalente de C3b à superfície de antígenos. A Via das Lectinas (ao centro) é ativada após a interação de lectinas como, por exemplo, a lectina ligadora de manose a açúcares bacterianos. As três vias resultarão na formação de C5 convertase, que clivará moléculas de C5 em C5a e C5b, sendo a C5b importante para a etapa tardia do complemento (caixa inferior à figura), iniciando a formação do MAC.

Fonte: Modificado de Walport (2001) 


\subsubsection{Proteína C5}

O componente C5 do Sistema Complemento é uma proteína solúvel, formada por duas cadeias ( $\alpha$ e $\beta$, com massas de 115 e $75 \mathrm{kDa}$, respectivamente) unidas entre si por uma ponte dissulfeto, composta por 1676 aminoácidos e massa de aproximadamente 190 kDa (Figura 6). Expressada principalmente por hepatócitos, é encontrada em concentrações séricas de aproximadamente $75 \mu \mathrm{g} / \mathrm{mL}$ em seres humanos (Morley, Walport, 2000).

Figura 6 - Representação das cadeias $\alpha$ e $\beta$ da proteína C5 unidas entre si por uma ponte dissulfeto

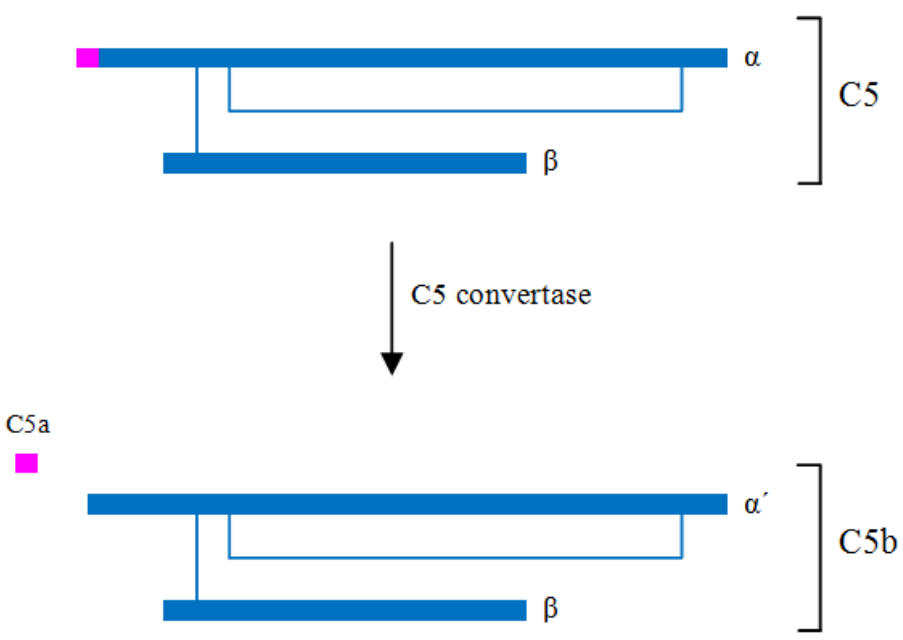

A ação da C5 convertase resulta na clivagem de C5 nos fragmentos C5a, oriundo da cadeia $\alpha$ e com aproximadamente $11 \mathrm{kDa}$, e C5b, que corresponde ao restante da proteína e possui aproximadamente $179 \mathrm{kDa}$. Figura cedida pela doutoranda Tatiana Rodrigues Fraga.

Localizado no cromossomo 2 murino, o gene que codifica para C5 é composto por aproximadamente $78 \mathrm{~kb}$, organizado em 42 éxons e 41 íntrons. Trabalhos do final dos anos 80 mostraram a presença de duas variantes alélicas desse gene em camundongos, sendo uma delas responsável pela ausência de C5 no soro e consequente falta de atividade hemolítica no soro das linhagens A/J, AKR e DBA (D’Eustachio et al., 1986). O sequenciamento de livrarias de cDNA indicaram que essa incapacidade para sintetizar C5 era causada por uma deleção de dois pares de base (TA) no éxon 7 do gene de $c 5$, resultando na formação de um códon de parada prematuro que impede a tradução do RNA mensageiro (RNAm) em uma proteína funcional (Haviland et al., 1991; Wetsel et al., 1990).

A formação de enzimas C5 convertases possibilita a clivagem de C5 em dois fragmentos C5a e C5b (Morley, Walport, 2000). C5a (Figura 7A), um fragmento de $11 \mathrm{kDa}$ e 74 aminoácidos, corresponde à região amino-terminal da cadeia alfa de C5 e permanece 
solúvel, tendo sua atividade mediada principalmente pelo receptor de C5a (C5aR - CD88) presente em diversos tipos celulares (Guo, Ward, 2005; Monk et al., 2007; Morley, Walport, 2000). Uma vez formado, este fragmento é rapidamente clivado por peptidases presentes no sangue que removem o aminoácido arginina da porção C-terminal do fragmento, dando origem ao fragmento chamado C5adesArg (Bokisch, Müller-Eberhard, 1970). Embora menos potente, C5adesArg é capaz de desempenhar funções semelhantes às de C5a (Eglite et al., 2000; el-Lati et al., 1994), sendo capaz de interagir com os mesmos receptores (Cain et al., 2001; Scola et al., 2007). Maior fragmento de C5, C5b possui 1602 aminoácidos e massa de $179 \mathrm{kDa}$, correspondendo ao restante da cadeia $\alpha\left(\alpha^{\prime}, 104 \mathrm{kDa}\right)$ que permanece unida à cadeia $\beta(75 \mathrm{kDa})$. Esse fragmento é responsável por iniciar a formação do MAC (Figura 7B), uma estrutura capaz de formar poros na membrana da célula onde há ativação do Sistema Complemento e estimular células do organismo durante a inflamação (Dobrina et al., 2002). Outras funções biológicas de C5b serão abordadas no item 1.2.5.2.

Figura 7 - Estrutura de C5a e do MAC

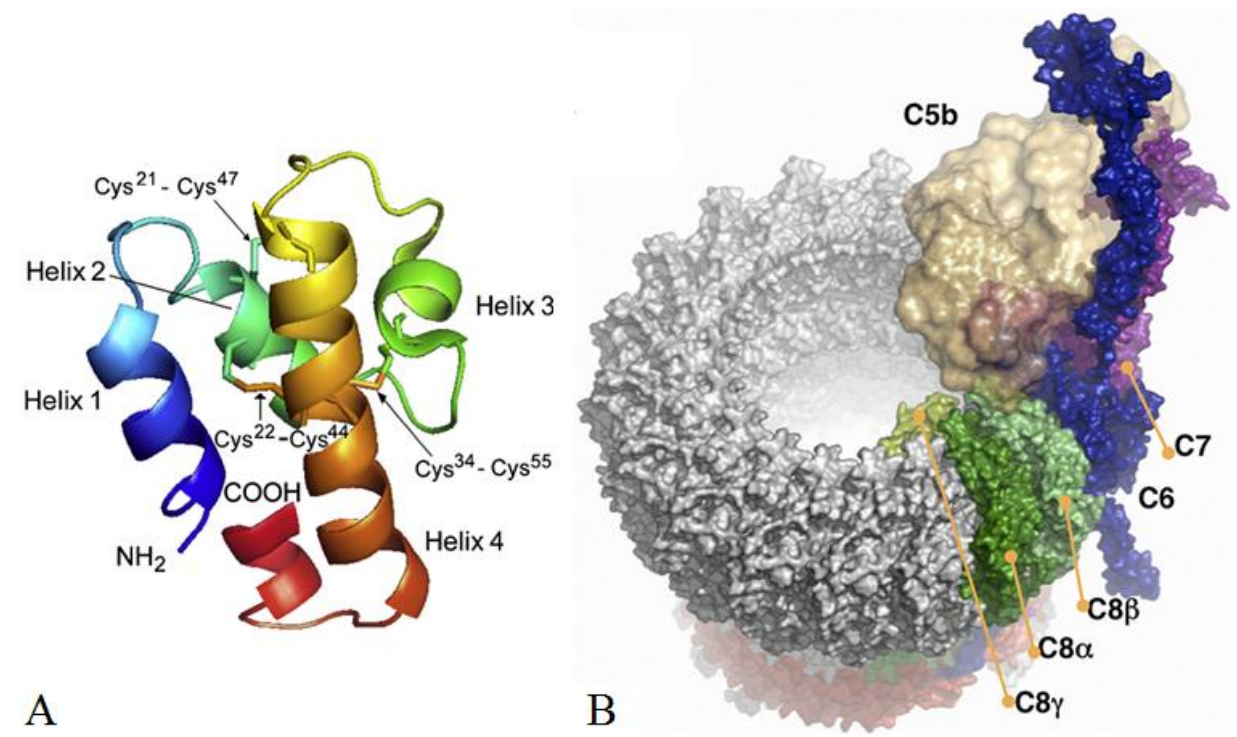

O fragmento C5a (A) tem origem a partir da clivagem da cadeia $\alpha$ de C5 pela C5 convertase e é composto por 74 aminoácidos organizados em $4 \alpha$-hélices (Manthey et al., 2009). O maior fragmento gerado na clivagem de C5 é chamado de C5b e, após interagir com moléculas de C6, C7, C8 e diversas proteínas C9 forma o complexo C5b6789 $(\mathrm{n})$, também denominado MAC (B - Aleshin et al., 2012).

\subsubsection{Atividade de C5a}

Inicialmente descrito como uma molécula com capacidade quimiotática, o fragmento C5a desempenha diversas funções no organismo, participando da resposta imune através do 
estimulo à desgranulação de mastócitos, aumento da síntese de moléculas de adesão por células endoteliais, atração de leucócitos circulantes para o sítio inflamatório, elevação da capacidade de eliminação de partículas fagocitadas por neutrófilos e macrófagos e aumento da síntese e liberação de citocinas por diferentes tipos celulares (Manthey et al., 2009). Diversos trabalhos também mostram a importância de C5a para a manutenção da homeostase do organismo, sendo importante nos processos de reparação tecidual, promoção de angiogênese e produção de fatores de crescimento (Markiewski et al., 2009; Mastellos et al., 2001).

Primeiro receptor de C5a descrito, C5aR é uma proteína de membrana que permanece acoplada a uma proteína G (Figura 8). O estímulo deste receptor com C5a e C5adesArg causa diversos efeitos na célula, como aumento da concentração de cálcio intracelular, ativação de diferentes cascatas de sinalização e alteração da transcrição gênica (Monk et al., 2007). Apesar da similaridade com C5aR, C5L2 (Figura 8), outro receptor de C5a e C5adesArg, não permanece acoplado a nenhuma proteína G, não estando ainda elucidados o seu mecanismo de ação e sua função biológica. Há trabalhos que sugerem um papel na competição e retirada de C5a e C5adesArg da circulação, minimizando os efeitos pró-inflamatórios desses fragmentos (Gao et al., 2005; Gerard et al ., 2005). No entanto, outros estudos mostram que animais deficientes de C5L2 têm uma resposta reduzida a determinados estímulos inflamatórios (Chen et al., 2007).

Figura 8 - Receptores de C5a

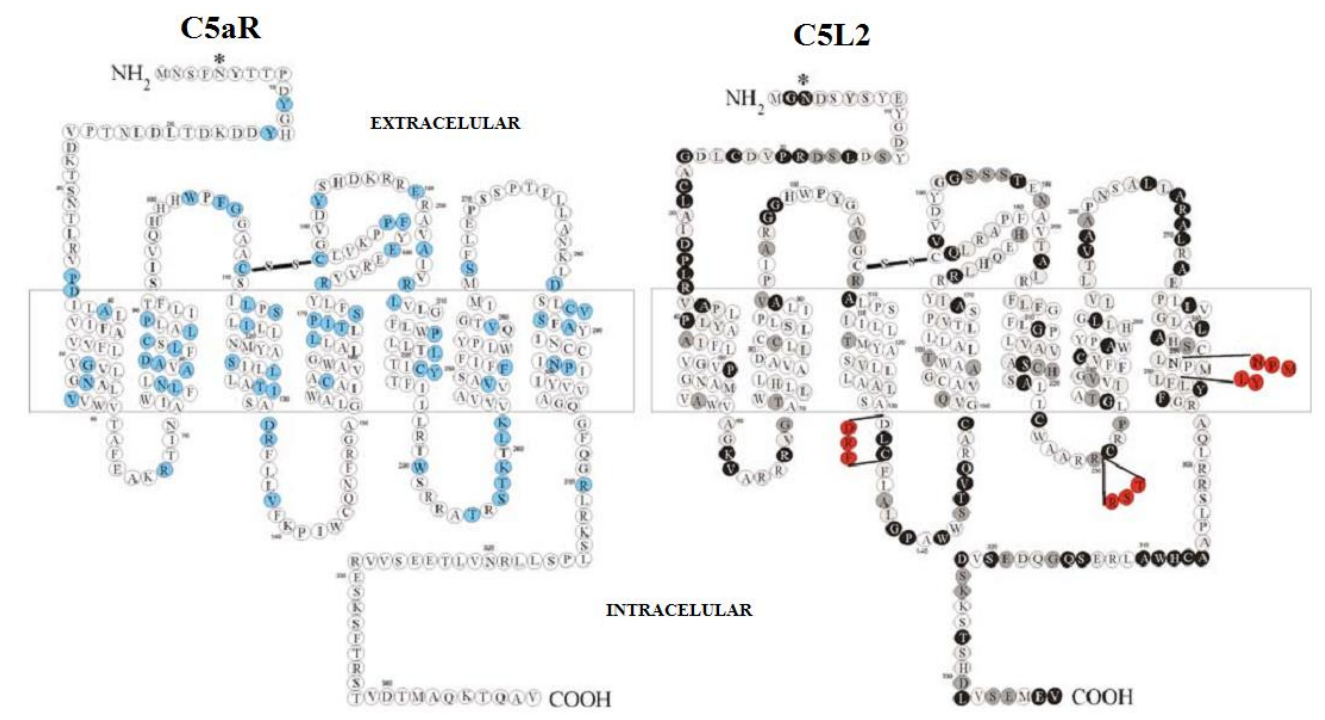

Os receptores C5aR e C5L2 são estruturalmente semelhantes entre si, possuindo uma região N-terminal extracelular, sete porções transmembrana e uma cauda C-terminal intracelular. Os resíduos marcados em vermelho em C5L2 correspondem à resíduos presentes em C5aR que são importantes para o acoplamento da proteína G. Adaptado de Monk et al., 2007. 
Trabalhos da década de 70 já mostravam a importância de C5 para a atração de leucócitos aos sítios inflamatórios (Snyderman et al., 1971; Ward, Zvaifler, 1971). O acompanhamento de camundongos C5 deficientes inoculados intraperitonealmente com endotoxinas de Salmonella typhosa mostrou que o acúmulo de células polimorfonucleares (PMN) na cavidade peritoneal era bastante reduzido em relação aos animais C5 normais (Snyderman et al., 1971). A incubação de células de animais C5 deficientes com soro de camundongos C5 normais mostrou a capacidade de resposta quimiotática por esses leucócitos, indicando que a deficiência para C5 não influencia a aptidão de PMN para responder a fatores quimiotáticos presentes no soro. Contudo, a ausência de C5 no soro diminui a atividade de PMN de camundongos C5 normais e C5 deficientes, sugerindo a importância dessa proteína para a atração desses leucócitos. Assim como PMN, monócitos também são atraídos por C5a, sendo esse efeito mantido mesmo quando essas células são estimuladas com C5adesArg, embora a atividade desempenhada por este fragmento seja aproximadamente 100 vezes menor em relação à C5a (Marder et al., 1985).

Segundo diferentes estudos, esse efeito quimiotático de PMN é dependente de C5aR e se estende a diferentes tipos celulares. Camundongos C5aR deficientes apresentam menor atração de neutrófilos para sítios de injúria (Xu et al., 2009). Linfócitos T ativados aumentam a expressão deste receptor e também são atraídos por fragmentos de C5a (Nataf et al., 1999).

Granulócitos incubados com E. coli na presença de inibidores de C5aR apresentam menor produção de espécies reativas de oxigênio e, da mesma forma que monócitos, têm menor capacidade de fagocitose (Mollnes et al., 2002).

Camundongos C5 deficientes possuem menor atividade de linfócitos T CD4 ${ }^{+}$, macrófagos e células dendríticas (Liu et al., 2013; Mashruwala et al., 2011; Moulton et al., 2007). Macrófagos e células dendríticas desses animais produzem menores quantidades de IL-12p70 que as células de animais C5 normais. Essa pequena produção de IL-12(p70) junto à ausência de C5a leva a menor ativação dos linfócitos $\mathrm{T} \mathrm{CD}^{+}$, resultando em menor produção de IFN- $\gamma$ por essas células (Mashruwala et al., 2011; Moulton et al., 2007). Essa maior dificuldade em organizar uma resposta Th1 pode explicar a maior susceptibilidade de camundongos C5 deficientes a bactérias do gênero Mycobacterium.

C5a também é importante para o controle de infecções virais. A inibição da interação C5a-C5aR é capaz de reduzir a resposta antiviral dependente de linfócitos T CD8 ${ }^{+}$, ocasionando menor produção de IFN- $\gamma$ e atividade lítica reduzida contra células infectadas (Kim et al., 2004). 


\subsubsection{Atividade de C5b}

A ativação do Sistema Complemento resulta, independente da via de ativação, na formação do MAC. Devido à sua capacidade de interagir com a superfície de células e formar poros capazes de causar sua lise, sua função lítica foi a primeira a ser descrita e melhor conhecida.

Entretanto, bactérias gram-positivas e microorganismos encapsulados geralmente são resistentes a essa atividade do MAC. Diferentes microorganismos também utilizam diversos mecanismos para evadir a lise mediada pelo complemento, seja através da secreção de enzimas que clivam proteínas do complemento, ou pela interação com reguladores presentes no organismo que impedem a ativação desse sistema sobre sua superfície.

Essas dificuldades impostas pelos microorganismos para a atividade lítica do MAC geram questionamentos sobre a possibilidade deste complexo desempenhar outras funções além da lise celular. Assim como C5a, quando presente na fase aquosa, o MAC é capaz de induzir a quimiotaxia e migração de leucócitos através do estímulo à produção de IL-8 e MCP-1 pelas células endoteliais (Dobrina et al., 2002).

Além dessa função quimiotática, a participação conjunta entre o MAC e o inflamassoma NLRP3 (proteína 3 estruturalmente composta pelo domínio pirina, domínio com repetições ricas em leucina (LRR) e domínio NACHT) para a síntese e liberação de IL-1 $\beta$ por células dendríticas estimuladas por LPS foi recentemente proposta. Na ausência do MAC, embora haja produção de pró-IL-1 $\beta$, não ocorre a ativação da caspase-1, impedindo a maturação e liberação desta citocina (Laudisi et al., 2013).

\subsection{Importância do Sistema Complemento na leptospirose}

Estudos recentes desenvolvidos por nosso grupo têm demonstrado diferentes estratégias utilizadas in vitro por leptospiras patogênicas para escaparem da atividade do Sistema Complemento e, dessa forma, conseguirem se fixar no organismo (Barbosa et al., 2009; Castiblanco-Valencia et al., 2012). Contudo, pouco é conhecido sobre a participação do Sistema Complemento na infecção por leptospiras em modelos in vivo.

Assim como bactérias de outras espécies, as leptospiras patogênicas são capazes de se ligar aos reguladores do Sistema Complemento. Estudos iniciais mostraram a capacidade de diferentes sorovares de leptospiras se ligarem aos reguladores FH e C4BP (Barbosa et al., 2009; Castiblanco-Valencia et al., 2012; Meri et al., 2005; Silva et al., 2011). 
Trabalhos in vitro ainda mostraram que, quando comparada à L. biflexa e à L. interrogans sorovar Pomona (atenuada pelas várias passagens em meio de cultura e por isso possui menor patogenicidade), bactérias patogênicas como a L. interrogans sorovar Kennewicki estirpe Pomona Fromm (LPF) ligam menores quantidades de diversas proteínas do Sistema Complemento, entre elas C5, em sua superfície, quando incubadas com soro (Barbosa et al., 2009).

Por meio da proteína LcpA, ausente na L. biflexa (não patogênica), a LPF interage com C4BP, um importante regulador da Via Clássica e das lectinas que acelera o decaimento da C3 convertase dessas vias e atua como cofator do FI para a clivagem de C4b em C4c e C4d (Barbosa et al., 2010). C4BP e Fator H (FH) interagem com as proteínas LigA e LigB, ambas presentes na LPF e ausentes na L. biflexa. Uma vez que essa interação ocorre, essas proteínas mantêm sua atividade regulatória, com C4BP atuando na clivagem de $\mathrm{C} 4 \mathrm{~b}$ e o $\mathrm{FH}$ na clivagem de C3b, ambos como co-fatores de FI (Castiblanco-Valencia et al., 2012).

Além da interação com proteínas reguladoras, leptospiras patogênicas secretam enzimas capazes de clivar diferentes componentes do Sistema Complemento, como C3 e seus fragmentos $\mathrm{C} 3 \mathrm{~b}$ e iC3b, C2, C4 e FB, diminuindo a atividade das três vias de ativação do Sistema Complemento (Fraga et al., 2014).

Essa capacidade da LPF em se ligar a diferentes reguladores do Sistema Complemento de forma que eles permaneçam ativos e clivem seus respectivos substratos, além da clivagem de diferentes proteínas, como C3 e seus fragmentos gerados após a ativação do sistema, através da secreção de enzimas, reduzindo a deposição de proteínas do Sistema Complemento permite explicar a maior sobrevivência da LPF à lise mediada pelo Sistema Complemento em relação a L. biflexa (Barbosa et al., 2009), que não possui os mesmos mecanismos de escape da resposta imune do hospedeiro.

Apesar de haver estudos experimentais que empregam modelos in vivo de infecção com leptospiras, há escassez de trabalhos que demonstrem a real importância do Sistema Complemento na leptospirose. A utilização de modelos murinos que empreguem deficiência de C5 e, devido a esta característica tenham alterações desde a quimiotaxia de leucócitos para locais de ativação do Sistema Complemento até mesmo uma potencial menor atividade dessas células, pode contribuir com informações relevantes sobre a ação desse sistema na infecção e sobre a própria importância da funcionalidade do Sistema Complemento na capacidade do organismo reagir a um estímulo agressor e controlar o grau de lesão que pode ser gerado nesse processo. 
Com o objetivo de entender melhor a importância in vivo do Sistema Complemento para o controle da infecção por leptospiras, propusemos o emprego de linhagens murinas que possuam as três vias funcionais (C57B1/6 - ou B6) ou que tenham falhas devido à ausência de C5 (A/J). Considerando que essas linhagens além da presença ou ausência de C5 têm diferente fundo genético, utilizamos também linhagens congênicas, A.B6-Hc (A/J $\mathrm{C}^{+/+}$$\left.\mathrm{C}^{+}\right)$e B6.A-Hc ${ }^{0}\left(\mathrm{~B} 6 \mathrm{C}^{-{ }^{-}}-\mathrm{C} 5^{-}\right)$, ambas desenvolvidas em nosso laboratório (Bavia et al., 2014), para delimitar qual é o papel real dessa proteína, no controle efetivo desta infecção. 


\section{OBJETIVOS}

\subsection{Objetivos gerais}

Verificar a importância de C5 para a resposta imunológica de camundongos contra leptospiras patogênicas. Para responder a esta pergunta, foram verificadas a resposta imune de linhagens isogênicas de camundongos, uma C5 deficiente (A/J C5) e outra C5 suficiente (B6 $\mathrm{C}^{+}$) e seus respectivos congênicos A/J C5 suficiente (A/J C5 ${ }^{+}$) e $\mathrm{C} 57 \mathrm{~B} 1 / 6 \mathrm{C} 5$ deficiente (B6 C5), frente à infecção por L. interrogans sorovar Kennewicki estirpe Pomona Fromm (LPF), de forma a identificar mecanismos que poderiam ser prejudicados ou beneficiados pela presença ou pela ausência de C5.

\subsection{Objetivos específicos}

1. Definir o melhor tempo de infecção e a melhor dose para o inóculo a ser utilizada;

2. Verificar se há diferença na capacidade de eliminar leptospiras no fígado e nos rins a partir de cultivo bacterianos desses órgãos;

3. Quantificar o número de leucócitos circulantes no sangue periférico e determinar a proporção dos principais tipos celulares durante a infecção nas quatro linhagens;

4. Acompanhar o desenvolvimento de esplenomegalia nas linhagens B6 C5 ${ }^{+}$, B6 C5; $\mathrm{A} / \mathrm{J} \mathrm{C}^{+}$e A/J C5;

5. Verificar se ocorrem alterações nas concentrações de enzimas hepáticas (ALT e AST), ureia e ácido úrico no soro dos camundongos infectados, um indicativo de lesão hepática e/ou renal;

6. Quantificar a concentração de citocinas no soro, fígado, rim e pulmão dos camundongos por CBA ou ELISA.

7. Determinar se ocorrem alterações histopatológicas no fígado, rim, pulmão e baço durante a infecção; 


\section{MATERIAL E MÉTODOS}

\subsection{Obtenção e condições de cultivo de Leptospira interrogans}

Bactérias patogênicas de Leptospira interrogans sorovar Kennewicki, estirpe Pomona Fromm (LPF) foram obtidas no laboratório do Prof. Dr. Silvio de Arruda Vasconcellos, da Faculdade de Medicina Veterinária e Zootecnia da Universidade de São Paulo, a partir de extratos do fígado de hamsters sírios infectados com leptospiras virulentas, sendo mantidas em condições aeróbicas a $29{ }^{\circ} \mathrm{C}$, em meio de cultura Ellinghausen McCullough Johnson and Harris (EMJH - - BD Difco ${ }^{\mathrm{TM}}$, Franklin Lakes, New Jersey, Estados Unidos) contendo $10 \%$ de soro de coelho (Bio Nutrientes, Barueri, São Paulo, Brasil), com adição de L-asparagina (0,015\% - Inlab, Diadema, São Paulo, Brasil), piruvato de sódio (0,001\% - Inlab), cloreto de cálcio (0,001\% - Sigma, Saint Louis, Missouri, Estados Unidos), cloreto de magnésio $(0,001 \%$ - Merck, Whitehouse Station, New Jersey, Estados Unidos), peptona (0,03\% - BD Difco $\left.^{\mathrm{TM}}\right)$ e extrato de carne $\left(0,02 \%\right.$ - BD Difco $\left.{ }^{\mathrm{TM}}\right)$.

\subsection{Obtenção dos animais}

Os camundongos das linhagens A/J $\left(\mathrm{C}^{-1-}\right)$, A.B6-Hc (camundongo com fundo genético $\mathrm{A} / \mathrm{J}$ onde foi inserido o alelo funcional do gene $\left.\mathrm{C} 5-\mathrm{C}^{+/+}\right), \mathrm{C} 57 \mathrm{~B} 1 / 6\left(\mathrm{C} 5^{+/+}\right)$e B6. A-Hc ${ }^{0}$ (camundongo com fundo genético $\mathrm{C} 57 \mathrm{~B} 1 / 6$ onde foi inserido o alelo não funcional do gene $\mathrm{C} 5-\mathrm{C}^{-1-}$ ). Para facilitar a identificação das linhagens e o entendimento do texto, identificaremos a linhagem $\mathrm{A} / \mathrm{J} \mathrm{C5}{ }^{-/-}$por $\mathrm{A} / \mathrm{J} \mathrm{C5}$, A.B6-Hc por A/J C5 ${ }^{+}, \mathrm{C} 57 \mathrm{~B} 1 / 6$ por B6 $\mathrm{C}^{+}$ e B6.A-Hc ${ }^{0}$ por B6 $\mathrm{C}^{-}$. Todos os camundongos, machos com idades entre 6 e 8 semanas, foram obtidos do Biotério de Camundongos Isogênicos do Departamento de Imunologia, sendo transferidos para o Biotério de Experimentação do Departamento de Microbiologia do Instituto de Ciências Biomédicas (ICB) da USP. Os camundongos infectados e acompanhados por 3 semanas possuíam 8 semanas de idade quando foram utilizados, enquanto os animais empregados no modelo de 6 dias de infecção possuíam entre 6 e 8 semanas de idade. Também foram utilizados hamsters sírios do laboratório do Prof. Silvio de Arruda Vasconcelos com idades semelhantes às dos camundongos. Todo a trabalho foi executado conforme aprovado pela Comissão de Ética no Uso de Animais no certificado 061/10/CEUA. 


\subsubsection{Geração dos camundongos congênicos}

Os camundongos congênicos foram gerados em nosso laboratório pela Dra. Lorena Bavia durante o desenvolvimento de sua tese de doutorado (Bavia et al., 2014) com a nossa participação. Camundongos das linhagens B6 $\mathrm{C5}^{+}$(selvagem) e A/J C5- (mutante), denominados parentais (P) foram acasalados para obtenção da geração F1 híbrida que continha ambos os alelos de C5. Os animais F1 foram então cruzados com uma das linhagens parentais, sendo a prole obtida denominada N2, onde apenas os animais heterozigotos foram selecionados para futuros retrocuzamentos. A geração N2 foi cruzada com as respectivas linhagens parentais gerando N3, sendo esse processo sucessivamente repetido até a geração N10, quando os camundongos obtidos foram submetidos a acasalamentos entre irmãos. A prole gerada foi selecionada pela presença em homozigose dos alelos de C5, sendo a cópia selvagem fixada no fundo genético $\mathrm{A} / \mathrm{J}\left(\mathrm{A} / \mathrm{J} \mathrm{C}^{+}\right)$e a cópia com a deleção de TA no éxon 7 do gene de C5 fixada em B6 (B6 C5) (Figura 9).

Figura 9 - Modelo de geração das linhagens congênicas

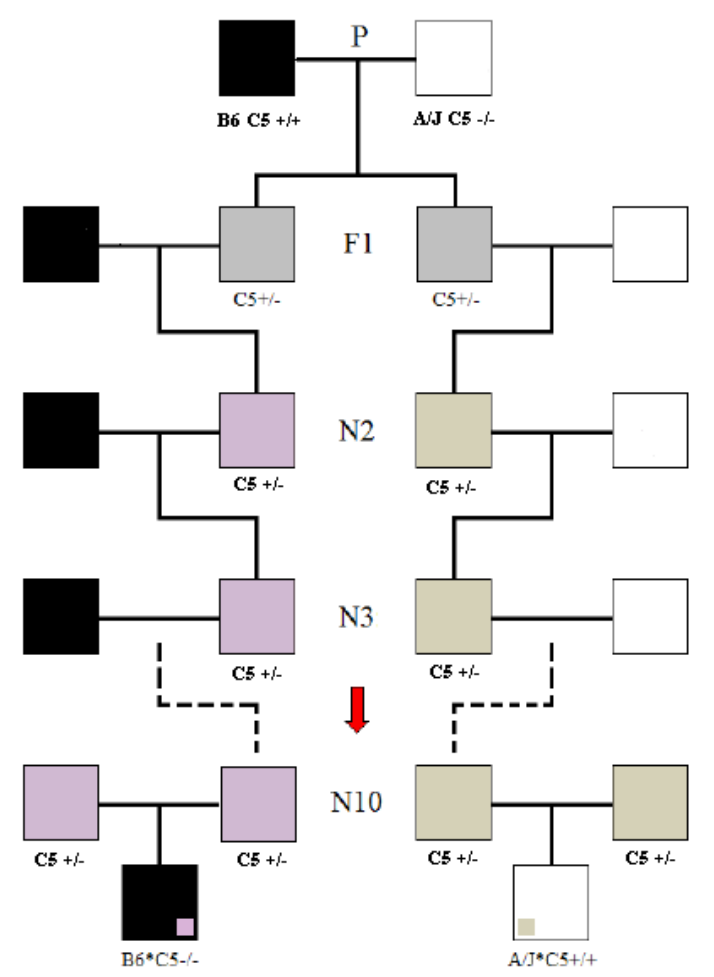

Camundongos das linhagens parentais $(\mathrm{P}) \mathrm{A} / \mathrm{J}\left(\mathrm{C}^{-/}\right)$e $\mathrm{B} 6\left(\mathrm{C}^{+/+}\right)$foram acasalados, dando origem à geração $\mathrm{F} 1$ heterozigota. $\mathrm{O}$ retrocruzamento dos animais da geração $\mathrm{F} 1$ com A/J e de $\mathrm{F} 1$ com B6 deu origem à geração N2, onde foram selecionados os animais heterozigotos. Esse processo foi repetido até a geração N10, quando houve cruzamento consanguíneo entre irmãos para posterior seleção dos animais homozigotos, sendo obtidas as linhagens B6 C5 e A/J C5 . Fonte: Bavia et al., 2014. 
A validação das linhagens $\mathrm{A} / \mathrm{J} \mathrm{C}^{+}$e $\mathrm{B} 6 \mathrm{C5}^{-}$foi realizada por amplificação e comparação de regiões de microssatélites dos camundongos congênicos com os respectivos parentais. A confirmação da presença ou ausência da proteína C5 nos camundongos congênicos foi feita por meio do sequenciamento de nucleotídeos da região próxima da extremidade 5' do éxon 7 do gene dessa proteína, imunoprecipitação para detecção de C5 no soro e verificação da atividade hemolítica mediada pela via alternativa para determinar a atividade do Sistema Complemento (Bavia et al., 2014).

\subsection{Preparação dos inóculos com LPF}

Leptospiras virulentas no sétimo dia de cultivo em $2^{a}$ passagem em meio EMJH foram contadas em câmara de Petroff-Hauser em microscópio óptico Olympus BX51 (Olympus, Shinjuku, Tóquio, Japão) empregando condensador de campo escuro Olympus U-DCD (Olympus). Elas foram então centrifugadas a $4487 \mathrm{~g}, 20^{\circ} \mathrm{C}$ por $25 \mathrm{~min}$, sendo o meio de cultura descartado e as bactérias ressuspendidas em PBS 1x pH 7,4 (0,130 M de NaCl, 0,002 $\mathrm{M}$ de $\mathrm{KCl}, 0,010 \mathrm{M}$ de $\mathrm{Na}_{2} \mathrm{HPO}_{4}$ e $0,001 \mathrm{M}$ de $\mathrm{KH}_{2} \mathrm{PO}_{4}$ ) na concentração de 2 x $10^{9} \mathrm{LPF}$ por $\mathrm{mL}$. A partir dessa suspensão foram preparados inóculos contendo $10^{3}, 10^{5}, 10^{7}$ e $10^{9} \mathrm{LPF}$ em $500 \mu \mathrm{L}$ para o experimento de longo tempo de infecção e $10^{7}$ ou $1,5 \times 10^{8}$ LPF com volume final de $300 \mu \mathrm{L}$ para o modelo de curto tempo de infecção. Também foram preparados inóculos contendo apenas PBS estéril para ser utilizado como dose controle.

\subsection{Infecção dos camundongos}

A inoculação de leptospiras nos animais ocorreu por via intraperitonial. Para o modelo de longo tempo de infecção inoculamos 25 A/J C5 e 25 B6 C5 ${ }^{+}$, sendo cinco animais de cada linhagem por dose e outros cinco animais somente com PBS estéril. Todos os animais foram eutanasiados na $3^{\text {a }}$ semana da infecção. Para o modelo de curto tempo de infecção com $10^{7} \mathrm{LPF}$ inoculamos $11 \mathrm{~A} / \mathrm{J} \mathrm{C5}^{-}$e $12 \mathrm{~B} 6 \mathrm{C}^{+}$, dos quais $5 \mathrm{~A} / \mathrm{J} \mathrm{C5}^{-}$e $6 \mathrm{~B} \mathrm{C}^{+}$foram eutanasiados no $3^{\circ}$ dia após o início do experimento e o restante eutanasiado no $6^{\circ}$ dia. Também inoculamos 6 camundongos A/J C5 e 4 camundongos $\mathrm{B} 6 \mathrm{C}^{+}$com PBS, que foram eutanasiados no $6^{\circ}$ dia do experimento. Para o experimento de curto tempo de infecção com $1,5 \times 10^{8} \mathrm{LPF}$, inoculamos as leptospiras em 22 camundongos A/J C5 ${ }^{+}, 19 \mathrm{~A} / \mathrm{J} \mathrm{C5}, 20 \mathrm{~B} 6 \mathrm{C}^{+}$ e 22 B6 C5. Doze animais A/J C5 ${ }^{+}, 10$ A/J C5-, 10 B6 C5 ${ }^{+}$e 12 B6 C5 foram eutanasiados no $3^{\circ}$ dia de infecção, sendo o restante eutanasiados no $6^{\circ}$ dia. Quatro camundongos A/J $\mathrm{C}^{-}$e 
5 animais de cada uma das outras linhagens foram inoculados com PBS estéril e eutanasiados no $7^{\circ}$ dia do experimento e utilizados como grupo controle.

A cada experimento foram inoculados hamsters em paralelo para confirmação da virulência das bactérias, sendo todos acompanhados até o momento de sua morte. Para o experimento que envolveu a utilização de doses contendo diferentes quantidades de LPF foi utilizado um hamster por dose. O experimento de infecção com $10^{7}$ LPF utilizou somente um hamster como controle, que foi inoculado com o mesmo número de bactérias que os camundongos. Para o experimento de infecção com $1,5 \times 10^{8}$ LPF foram utilizados dois hamsters controle, sendo um dos animais infectado com a mesma dose de leptospiras que os camundongos, enquanto o outro foi infectado com $10^{9}$ LPF em uma suspensão de $500 \mu \mathrm{L}$.

\subsection{Eutanásia e coleta dos órgãos dos camundongos}

Os camundongos foram previamente anestesiados com ketamina (125 mg / kg) e xilazina $(12,5 \mathrm{mg} / \mathrm{kg})$. Após a confirmação da ausência de resposta a estímulos nas patas, os animais tiveram o sangue coletado pelo plexo retro-orbital através de capilares para microhematócrito heparinizados. O sangue coletado foi dividido para três preparações distintas. $\mathrm{Na}$ primeira, foram preparadas diluições do sangue em líquido de Türk (4,76 mM ácido acético, 6,25 $\mu \mathrm{M}$ azul de metileno) para contagem total de leucócitos periféricos. Na segunda preparação o sangue foi coletado na presença de EDTA 10\% pH 8 para evitar sua coagulação, utilizando-o para a caracterização das principais populações leucocitárias presentes. $\mathrm{O}$ restante do sangue coletado foi centrifugado a $1700 \mathrm{~g}$ por 15 min a $4{ }^{\circ} \mathrm{C}$, sendo alicotado e mantido a $-80{ }^{\circ} \mathrm{C}$ para posterior mensuração de citocinas e realização de testes para verificação da funcionalidade hepática e renal.

Após a eutanásia dos camundongos por deslocamento cervical, foram coletados o fígado, os rins, o baço e o pulmão. Antes da coleta do pulmão, foi realizada a perfusão do órgão com $10 \mathrm{~mL}$ de solução de $\mathrm{NaCl}$ 0,9\% injetada intra-cardiacamente.

Para a análise histopatológica foram coletados três lóbulos hepáticos, metade do rim direito, o baço e duas porções do pulmão, sendo todos mantidos em solução de formalina 3,7\% em PBS pH 7,4 durante 24 h, sendo então transferidos para uma solução de álcool 70\%. Amostras do fígado, do rim e do pulmão foram coletadas para detecção de leptospiras por PCR, sendo o restante o restante desses órgãos armazenados à $-80{ }^{\circ} \mathrm{C}$ para dosagem de citocinas. 
3.6 Determinação do crescimento do baço

O baço dos animais foi pesado durante sua extração, sendo o valor obtido normalizado em relação ao peso total do camundongo nesse mesmo dia, permitindo a comparação de sua massa entre animais com massas diferentes.

\subsection{Análises dos leucócitos sanguíneos}

O sangue foi diluído 20x em líquido de Türk para a contagem total de leucócitos em câmara de Neubauer. Para a análise da proporção entre leucócitos mononucleares (MN) e polimorfonucleares (PMN) foram contadas as 100 primeiras células encontradas nas lâminas, após extensão sanguínea e coloração com o kit Panótico Rápido (Laborclin, Pinhais, Paraná, Brasil).

A proporção entre linfócitos, monócitos e PMN foi obtida marcando-se essas células com anticorpos específicos conjugados com fluorocromos (Tabela 2 - Biolegend, San Diego, CA) para análise em citômetro de fluxo FACSCanto II (BD Bioscience, Franklin Lakes, New Jersey, Estados Unidos).

Para cada $100 \mu \mathrm{L}$ de sangue utilizamos $2 \mathrm{~mL}$ de tampão de lise $\left(155 \mathrm{mM}\right.$ de $\mathrm{NH}_{4} \mathrm{Cl}$, $10 \mathrm{mM}$ de $\mathrm{NaHCO}_{3}$ e $0,1 \mathrm{mM}$ de EDTA) para eliminar as hemácias e incubamos por 2 min à temperatura ambiente. Após lavar as amostras com $1 \mathrm{~mL}$ de PBS com $2 \%$ de soro fetal bovino (SFB) inativado pelo calor $\left(56^{\circ} \mathrm{C}\right.$ por $\left.30 \mathrm{~min}\right)$, centrifugamos a $600 \mathrm{~g}, 4^{\circ} \mathrm{C}$ por $5 \mathrm{~min}$ e descartamos o sobrenadante. Adicionamos FcR Blocking Reagent (Miltenyi Biotec, Bergisch Gladbach, Renânia do Norte-Vestfália, Alemanha) na diluição de 1:100 e incubamos as amostras por $20 \mathrm{~min}$ a $4^{\circ} \mathrm{C}$, adicionando em seguida os anticorpos (Tabela 2) na diluição de 1:100 seguido por incubação por $30 \mathrm{~min}$ a $4{ }^{\circ} \mathrm{C}$. Em seguida lavamos as amostras com PBS-SBF $2 \%$ antes de proceder com a leitura no citômetro de fluxo. A análise dos dados foi feita pelo software FlowJo (Treestar, Ashland, Oregon, Estados Unidos). 
Tabela 2 - Células marcadas e anticorpos utilizados para sua detecção

\begin{tabular}{|c|c|c|c|}
\hline Tipo celular & Fenótipo & Anticorpos anti- & Fluorocromo \\
\hline Monócitos & $\mathrm{CD}_{11 b^{+}}$ & CD11b & APC \\
\hline Linfócitos B & $\mathrm{CD}_{19}{ }^{+}$ & CD19 & FITC \\
\hline \multirow{2}{*}{ Linfócitos $\mathrm{T} \mathrm{CD} 8^{+}$} & $\mathrm{CD}^{-}$ & CD4 & APC-Cy7 \\
\hline & $\mathrm{CD}^{+}$ & $\mathrm{CD} 8$ & PercP \\
\hline \multirow{2}{*}{ Linfócitos $\mathrm{T} \mathrm{CD}^{+}{ }^{+}$ativados } & $\mathrm{CD}^{+}$ & CD8 & PercP \\
\hline & $\mathrm{CD} 25^{+}$ & CD25 & PE-Cy7 \\
\hline \multirow{2}{*}{ Linfócitos T CD4 ${ }^{+}$} & $\mathrm{CD}^{+}$ & CD4 & APC-Сy7 \\
\hline & $\mathrm{CD}^{-}$ & CD8 & PercP \\
\hline \multirow{2}{*}{ Linfócitos $\mathrm{T} \mathrm{CD}^{+}$ativados } & $\mathrm{CD}^{+}$ & CD4 & APC-Cy7 \\
\hline & $\mathrm{CD} 25^{+}$ & $\mathrm{CD} 25$ & PE-Cy7 \\
\hline Neutrófilos & $\operatorname{ly} 6 \mathrm{~g}^{+}$ & ly6g & $\mathrm{PE}$ \\
\hline
\end{tabular}

APC: aloficocianina; FITC: isotiocianato de fluoresceína; APC-Cy7: conjugado de aloficocianina e corante de cianina; PercP: Complexo protéico peridinina-clorofila; PE: R-ficoeritrina; PE-Cy7: conjugado de R-ficoeritrina e corante de cianina.

3.8 Estudo das funções hepática e renal

Para a mensuração indireta da integridade hepática foram dosadas as concentrações séricas das enzimas alanina aminotransferase (ALT) e aspartato aminotransferase (AST). Para verificar a funcionalidade renal foram dosadas as concentrações de ureia e ácido úrico no soro dos camundongos. Os kits utilizados nestes ensaios foram fornecidos pela Bioclin Quibasa (Belo Horizonte, Minas Gerais, Brasil) e, por serem destinados a amostras de pacientes humanos, foram adaptados para volumes menores, sendo utilizado o Biocontrol N (Bioclin Quibasa) como controle positivo das reações.

Foram utilizados $12,5 \mu \mathrm{L}$ de soro para a dosagem de ALT, $25 \mu \mathrm{L}$ para AST, $5 \mu \mathrm{L}$ para ureia e $12,5 \mu \mathrm{L}$ para ácido úrico.

\subsection{Homogeneização hepática}

Para a homogeneização do fígado, rim e pulmão, foi utilizado um tampão de lise (50 $\mathrm{mM}$ de Tris- $\mathrm{HCl} \mathrm{pH}$ 7,4, $1 \%$ de Nonidet P-40 (Roche, Indianápolis, Indiana, Estados Unidos), $0,25 \%$ de $\mathrm{C}_{24} \mathrm{H}_{39} \mathrm{NaO}_{4}, 150 \mathrm{mM}$ de $\mathrm{NaCl}, 1 \mathrm{mM}$ de EDTA, 1 comprimido de Cocktail Inhibitor Complete Roche (Roche) para cada $50 \mathrm{~mL}$ de solução, 17,5 $\mu \mathrm{g} / \mathrm{mL}$ de aprotinina, 5 $\mu \mathrm{g} / \mathrm{mL}$ de bestatina, $10 \mu \mathrm{g} / \mathrm{mL}$ de leupeptina, $1 \mathrm{mM}$ de $\mathrm{Na}_{3} \mathrm{VO}_{4}$ e $10 \mathrm{mM}$ de $\mathrm{Na}_{4} \mathrm{P}_{2} \mathrm{O}_{7}$ ) na proporção de $0,5 \mathrm{~mL}$ de solução para cada $0,1 \mathrm{~g}$ do tecido, a fim de evitar a degradação proteolítica espontânea. 
3.10 Dosagem de citocinas

A dosagem de citocinas foi realizada a partir de kits comerciais da BD Bioscience. Para as amostras de fígado, rim e pulmão foram utilizados sets de ELISA para TNF, IL-1 $\beta$, IL-6, IL-10, subunidade p40 de IL-12 (IL-12p40) e IL-12p70. As amostras foram diluídas em proporções variáveis entre 1:50 e 1:1000 de acordo com o kit e o órgão utilizados, permitindo a leitura correta da concentração de citocina. Os valores obtidos foram normalizados segundo a concentração total de proteínas no tecido, determinada pelo reagente Bio-Rad Protein Assay Dye Reagent Concentrate (Bio-Rad S.A., Hercules, Califórnia, Estados Unidos).

A concentração de citocinas no soro foi realizada com o kit CBA inflammation (BD Bioscience) sendo determinadas as concentrações de IFN- $\gamma$, MCP-1, TNF- $\alpha$, IL-6, IL-10 e IL12 p70 de acordo com o protocolo fornecido pela fabricante.

3.11 Análise histopatológica do fígado, rim, pulmão e baço

Os órgãos coletados para análise histopatológica foram mantidos em solução de formalina $4 \%$ por $24 \mathrm{~h}$, sendo então transferidos para etanol $70 \%$ até serem processados pelo Laboratório de Histotecnologia do Departamento de Imunologia do Instituto de Ciências Biomédicas da USP. Foram preparadas lâminas com cortes de $5 \mu \mathrm{m}$ coradas em hematoxilinaeosina (HE) para análise histopatológica e lâminas para execução de reação de imunohistoquímica (IH) para detecção de LPF com amostras dos órgãos de cada animal (subitem $3.14)$.

A análise histopatológica foi realizada em colaboração pelo Prof. Dr. Thales de Brito, do Instituto de Medicina Tropical da Faculdade de Medicina da USP. Os cortes histológicos dos camundongos foram primeiramente observados para a detecção das alterações desencadeadas pela infecção. Após essa etapa, cada animal foi avaliado de acordo com as alterações que apresentavam, sendo dadas as seguintes pontuações: 0 a 4 para o fígado (Tabela 3), 0 a 2 para o pulmão e 0 a 3 para o baço (Tabela 4). Devido à falta de lesões renais, não houve classificação deste órgão neste trabalho. 
Tabela 3 - Critérios para classificação histopatológica das alterações hepáticas no fígado de animais infectados com $1,5 \times 10^{8} \mathrm{LPF}$

\begin{tabular}{cc}
\hline Lesão observada & Grau de lesão \\
\hline Hipercelularidade sinusoidal + infiltrados leucocitários & 1 \\
Presença de células mitóticas & 1 \\
Destrabeculação dos hepatócitos & 1 \\
Presença de necrose celular & 1 \\
\hline
\end{tabular}

Fígado: Cada alteração observada adicionou 1 ponto na escala de lesão hepática. Animais que apresentaram apenas uma das alterações citadas foram classificados com lesão 1. Animais que apresentaram duas das lesões citadas foram classificados com lesão 2 . Animais que apresentaram três das lesões citadas foram classificados com lesão 3. Animais que apresentaram as quatro lesões citadas foram classificados com lesão 4.

Tabela 4 - Critérios para classificação histopatológica das alterações pulmonares e esplênicas em animais infectados com $1,5 \times 10^{8} \mathrm{LPF}$

\begin{tabular}{ccc}
\hline Órgão & Lesões observadas & Escala de lesão \\
\hline \multirow{2}{*}{ Pulmão } & Pneumonite Intersticial (PI) nodular & 1 \\
& PI difusa & 2 \\
\hline \multirow{2}{*}{ Baço } & Hiperplasia perifolicular & 1 \\
& Hiperplasia centrofolicular & 2 \\
& Hiperplasia mixta & 3 \\
\hline
\end{tabular}

Pulmão: Animais que apresentaram focos isolados de pneumonite intersticial foram classificados na escala de lesão 1. Animais com pneumonite intersticial difusa no pulmão foram classificados na escala de lesão 2.

Baço: Animais com hiperplasia perifolicular foram classificados na escala 1. Animais com hiperplasia centrofolicular foram classificados na escala 2. Animais com hiperplasia centro e perifolicular foram classificados na escala 3.

\subsection{Detecção de LPF por imuno-histoquímica}

Para a IH, os cortes histológicos foram desparafinizadas em xilol a $56{ }^{\circ} \mathrm{C}$ por $30 \mathrm{~min}$, reidratados após passagens em soluções de etanol absoluto seguidas por etanol $95 \%$ e água destilada e incubados em solução Dako target retrieval solution (Dako, Carpinteria, Califórnia, Estados Unidos) a $95{ }^{\circ} \mathrm{C}$ por $30 \mathrm{~min}$. $\mathrm{O}$ material foi resfriado à temperatura ambiente, lavado em água corrente e água destilada e tratado com dois banhos de 10 min com peróxido de hidrogênio 10 volumes (Vic Pharma Indústria e Comércio Ltda, Taquaritinga, São Paulo, Brasil) para bloqueio da atividade de peroxidases presentes nos tecidos analisados. Esse processo foi sucedido por nova lavagem dos cortes histológicos em água corrente e água destilada e bloqueio com PBS 0,01 M (Concentração dos sais) com 6\% de leite em pó (Nestlé Brasil Ltda, Araçatuba, São Paulo, Brasil).

Para marcação das leptospiras nos tecidos analisados, as lâminas foram incubadas por $18 \mathrm{~h}$ a $4{ }^{\circ} \mathrm{C}$ com anticorpo anti-leptospira produzido em coelho cedido pelo laboratório do 
Prof. Dr. Thales de Brito. Este anticorpo foi utilizado na proporção $1: 19.000$, sendo diluído em solução PBS com 1\% de BSA. Após 3 lavagens de 5 min em PBS, as lâminas foram incubadas por $30 \mathrm{~min}$ à temperatura ambiente com o anticorpo secundário EnVision+ SystemHRP Labelled Polymer Anti-Rabbit (Dako) de acordo com as instruções fornecidas pela fabricante, lavadas novamente 3 vezes com PBS e reveladas em solução de PBS com 0,00166 M de 3,3'-Diaminobenzidina tetrahidrocloreto hidrato (DAB - Sigma-Aldrich, Saint Louis, Missouri, Estados Unidos) e 2\% de peróxido de hidrogênio 10 volumes (Vic Pharma Indústria e Comércio Ltda) por 5 min, sendo então coradas por 1 min em hematoxilina.

A análise da marcação por IH também foi realizada em colaboração com o $\operatorname{Prof}^{\circ}$ Dr. Thales de Brito, sendo o fígado e o baço observados para diferenciar a intensidade de partículas de leptospira no organismo dos camundongos.

\subsection{Recuperação de bactérias viáveis do fígado e rim}

Após eutanásia dos camundongos infectados por leptospiras, uma porção do rim direito e um lóbulo do fígado foram coletados, e mantidos em solução de $\mathrm{NaCl}$ 0,9\% até serem macerados. O sobrenadante coletado foi aplicado em meio de cultura semi-sólido e, após cinco semanas, a presença de leptospiras foi analisada por microscopia óptica com condensador de campo escuro.

\subsection{Análise estatística}

Os resultados foram representados em gráficos com a média e o erro padrão de cada grupo. No modelo de três semanas de infecção, os resultados foram submetidos ao teste estatístico ANOVA one-way não paramétrico Kruskal-Wallis para cada linhagem (A/J C5 e B6 $\mathrm{C}^{+}$) separadamente, sendo utilizado o teste secundário de Dunns para encontrar as diferenças entre os diferentes tratamentos utilizados.

A análise do modelo de infecção de seis dias com $10^{7}$ LPF foi realizada pelo teste ANOVA two-way com o teste secundário de Tukey, sendo comparadas as diferenças entre os tempos de infecção e entre as linhagens $\mathrm{A} / \mathrm{J} \mathrm{C}^{-}$e $\mathrm{B} 6 \mathrm{C}^{+}$.

Para o modelo de infecção de seis dias com $1,5 \times 10^{8}$ LPF envolvendo o uso das linhagens $\mathrm{A} / \mathrm{J} \mathrm{C5}^{+}, \mathrm{A} / \mathrm{J} \mathrm{C5}^{-}, \mathrm{B} 6 \mathrm{C5}^{+}$e $\mathrm{B} 6 \mathrm{C}^{-}$foi utilizado o teste ANOVA three-way com teste secundário de Tukey.

Em todas as análises foi adotado nível de significância de pelo menos $5 \%$. 


\section{RESULTADOS}

Nas nossas tentativas iniciais de padronização do modelo de infecção in vivo empregamos camundongos $\mathrm{A} / \mathrm{J} \mathrm{C5}^{-}$e $\mathrm{B} 6 \mathrm{C}^{+}$.

4.1 Resultados do modelo de infecção por três semanas

\subsubsection{Recuperação de leptospiras no fígado e no rim}

O cultivo das amostras de fígado e rim indicou que a maioria dos camundongos, independente da linhagem foi capaz de controlar a infecção e eliminar LPF desses órgãos, sendo detectada a presença de microorganismos em amostras de fígado e rim de poucos animais de ambas as linhagens (Tabela 5), com exceção do grupo A/J C5 infectado com $10^{3} \mathrm{LPF}$, onde foram detectadas LPF em amostras de fígado de quatro camundongos e amostras de rim de dois animais.

Tabela 5 - Detecção de leptospiras no fígado e no rim de camundongos infectados com LPF

\begin{tabular}{ccccc}
\hline Tratamento & \multicolumn{2}{c}{ A/J C5 } & \multicolumn{2}{c}{ B6 C5 $^{+}$} \\
\hline & Fígado & Rim & Fígado & Rim \\
PBS & $0 / 5$ & $0 / 5$ & $0 / 5$ & $0 / 5$ \\
$\mathbf{1 0}^{3}$ LPF & $4 / 5$ & $2 / 5$ & $0 / 5$ & $0 / 5$ \\
$\mathbf{1 0}^{5}$ LPF & $1 / 5$ & $2 / 5$ & $0 / 5$ & $1 / 5$ \\
$\mathbf{1 0}^{7}$ LPF & $2 / 5$ & $1 / 5$ & $2 / 5$ & $0 / 5$ \\
$\mathbf{1 0}^{9}$ LPF & $0 / 5$ & $1 / 5$ & $1 / 5$ & $0 / 5$ \\
\hline
\end{tabular}

Número de camundongos A/J C5 e B6 C5 $5^{+}$inoculados com PBS $(\mathrm{n}=5), 10^{3}(\mathrm{n}=5), 10^{5}(\mathrm{n}=5), 10^{7}(\mathrm{n}=5)$ ou $10^{9}$ $(n=5)$ LPF onde foram encontradas LPF vivas em culturas do fígado e do rim após três semanas de infecção.

\subsubsection{Quantificação de leucócitos periféricos}

A contagem de leucócitos totais no sangue periférico indicou que não há alteração na quantidade dessas células em nenhuma das linhagens após três semanas de infecção (Figura 10A). Independentemente da dose aplicada, os grupos de animais infectados com LPF possuem quantidades similares de leucócitos sanguíneos em relação aos controles inoculados com PBS.

Contudo, a proporção entre células MN e PMN foi alterada, havendo aumento da porcentagem de PMN em ambas as linhagens (Figura 10). A linhagem B6 $\mathrm{C} 5^{+}$apresentou aumento da proporção de células PMN apenas quando inoculada com $10^{5}$ LPF (Figura 10B). 
Para camundongos A/J C5 a alteração ocorreu apenas quando os animais foram injetados com $10^{9}$ LPF (Figura 10C).

Figura 10 - Quantificação de leucócitos na circulação periférica de camundongos B6 $\mathrm{C}^{+}$e $\mathrm{A} / \mathrm{J} \mathrm{C5}$
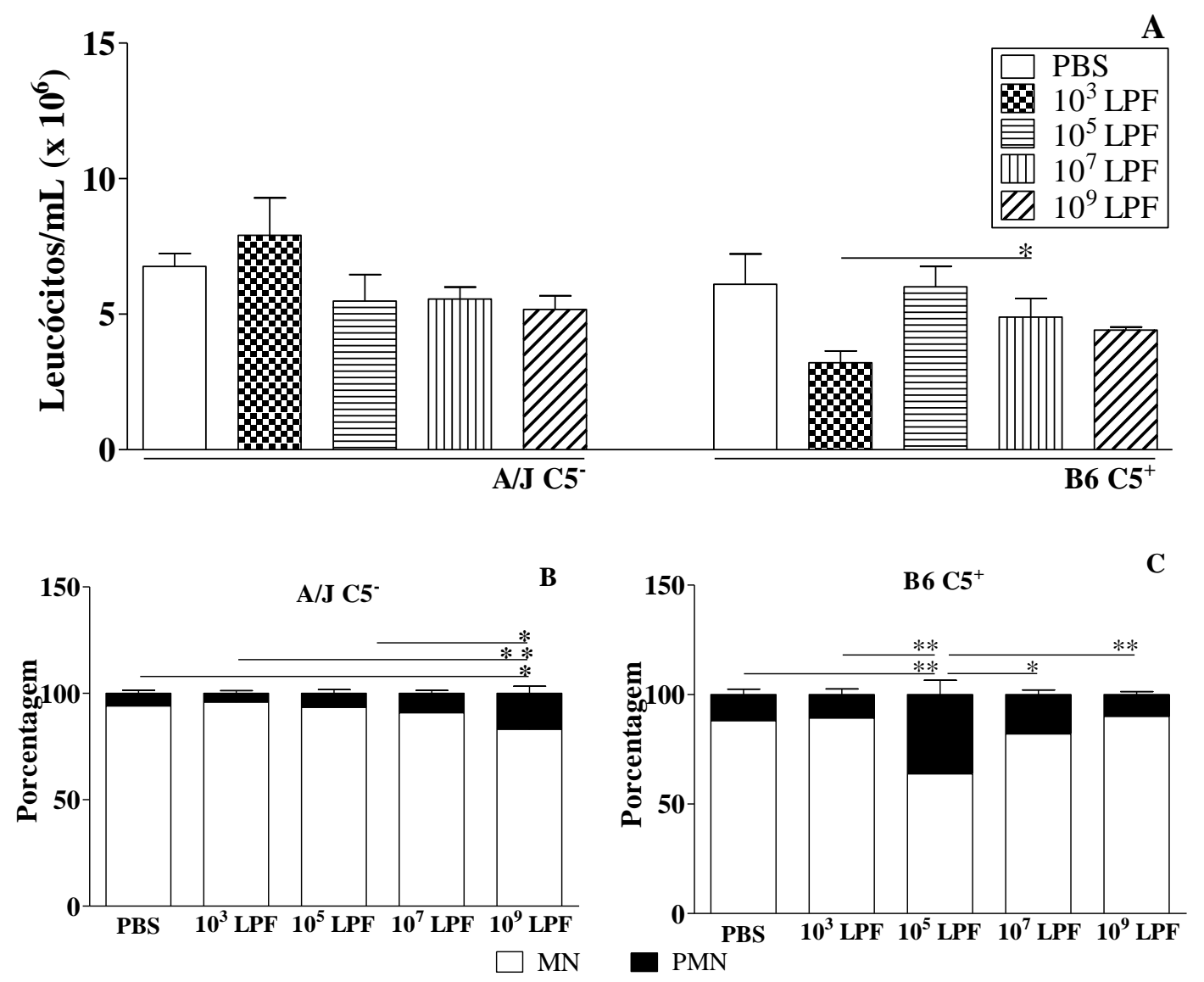

Número total de leucócitos presentes no sangue (A) e proporção de células MN e PMN na linhagem A/J C5 (B) e B6 $\mathrm{C}^{+}(\mathrm{C})$ três semanas após os animais terem sido inoculados com PBS $(\mathrm{n}=5), 10^{3}(\mathrm{n}=5), 10^{5}(\mathrm{n}=5), 10^{7}$ $(\mathrm{n}=5)$ ou $10^{9}(\mathrm{n}=5)$ LPF. $* p<0,05 ; * * p<0,01$

\subsubsection{Análise de função hepática}

As transaminases ALT e AST são responsáveis pela transferência do grupo amino entre os aminoácidos alanina e aspartato, respectivamente, e a molécula de $\alpha$-cetoglutarato, sendo importantes no processo de eliminação do grupo amino do organismo através da produção de ureia (Nelson, Cox, 2004) sendo encontradas em grande quantidade nos hepatócitos, células responsáveis pela produção de ureia que será posteriormente eliminada através da urina. A lesão de hepatócitos ocasiona a elevação dos níveis séricos de ALT e AST, de forma que concentrações altas dessas enzimas no soro podem sugerir lesões 
hepáticas no organismo. A análise dessas transaminases não evidenciou nenhuma alteração significativa das concentrações decorrente da infecção com LPF, não havendo indicação de lesão hepática nos animais, embora seja possível observar um aumento discreto dos níveis de ALT para ambas as linhagens e de AST para A/J C5 (Figura 11A e B) conforme aumenta o número de bactérias injetadas.

Figura 11 - Avaliação da função hepática de camundongos infectados com LPF

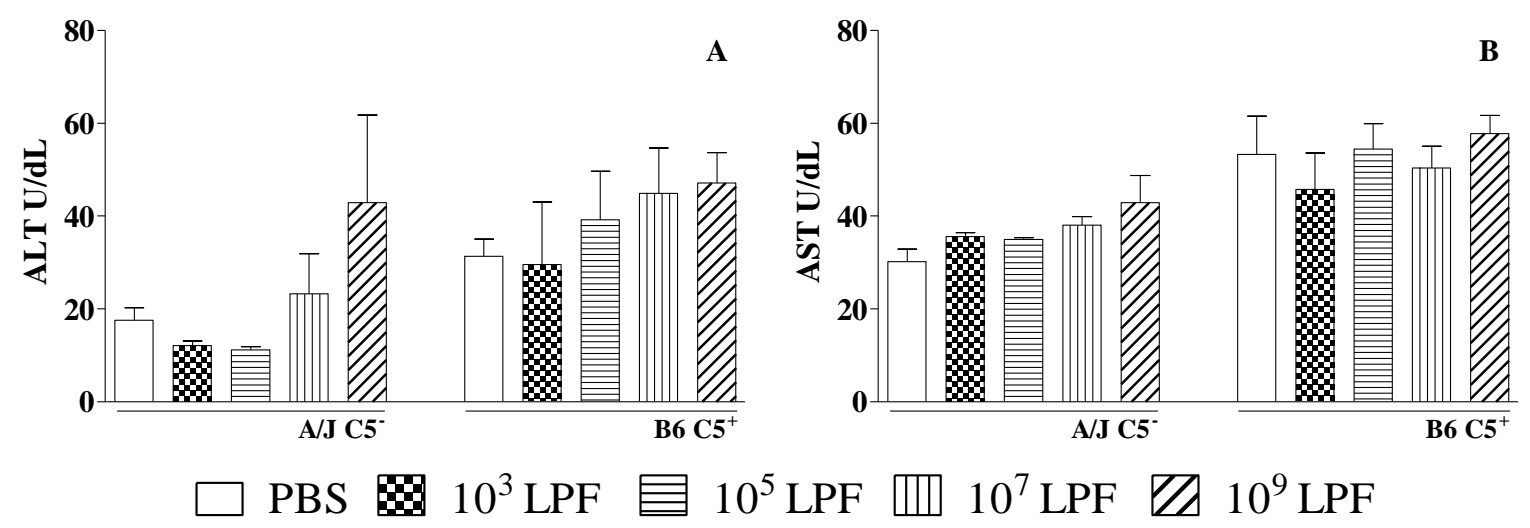

Concentração das enzimas hepáticas ALT (A) e AST (B) nos soros de camundongos das linhagens B6 $\mathrm{C}^{+}$e A/J C5 três semanas após terem sido inoculados com PBS $(n=5), 10^{3}(n=5), 10^{5}(n=5), 10^{7}(n=5)$ ou 10 $0^{9}(n=5)$ LPF.

\subsubsection{Dosagem de citocinas}

Não foram encontradas alterações nas concentrações hepáticas das citocinas TNF, IL-1 $\beta$, IL-6, IL-10, IL-12p40 e IL-12p70 após três semanas de infecção, sendo os níveis encontrados no fígado dos camundongos infectados semelhantes entre si e em relação aos animais controle (Figura 12). 
Figura 12 - Concentração de citocinas no fígado dos camundongos infectados com LPF
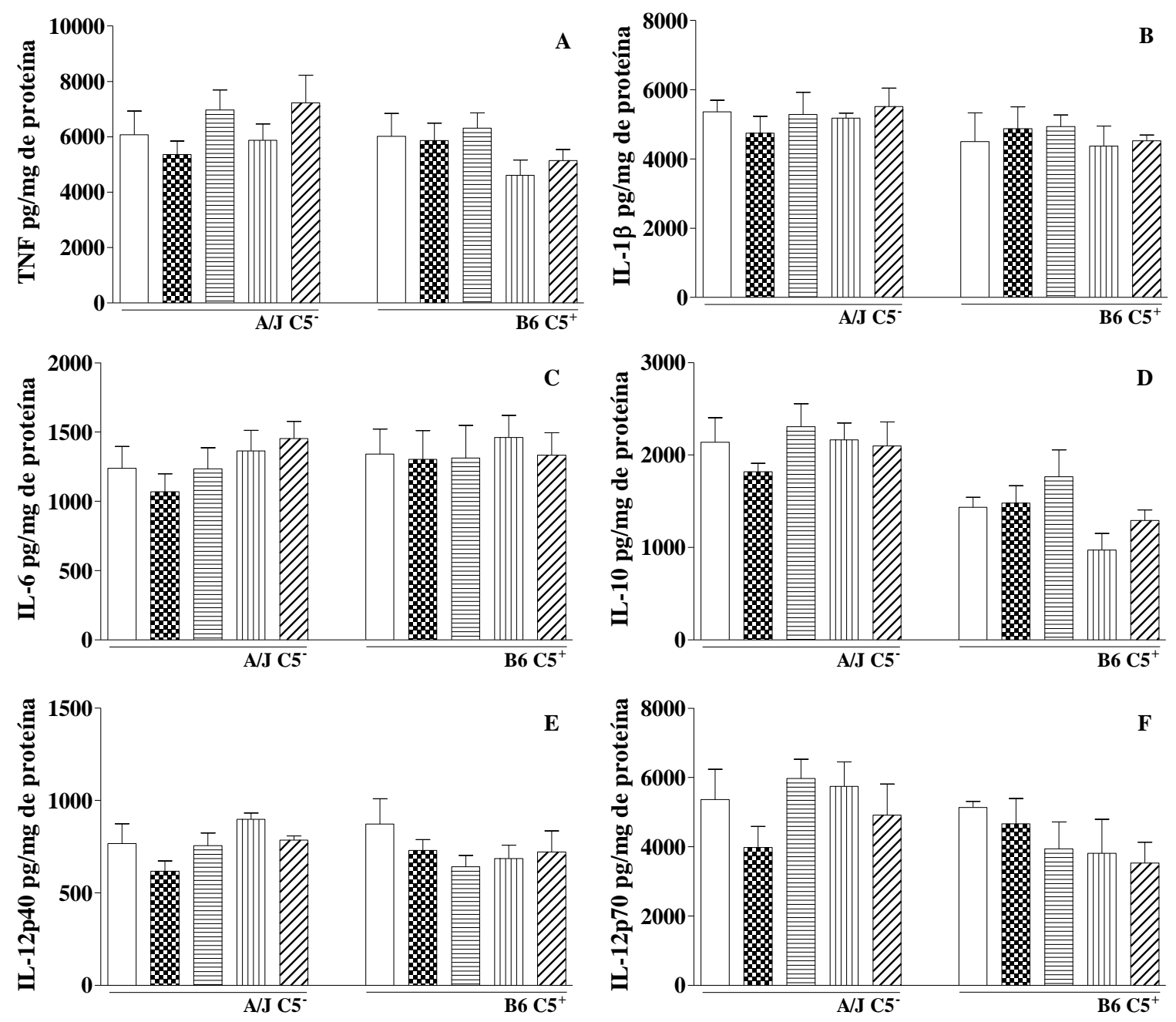

PBS $110^{3} \mathrm{LPF} \equiv 10^{5} \mathrm{LPF}$ 血 $10^{7} \mathrm{LPF} \square 10^{9} \mathrm{LPF}$

Concentração das citocinas TNF (A), IL-1ß (B), IL-6 (C), IL-10 (D), IL-12(p40) (E) e IL-12(p70) (F) no fígado de camundongos das linhagens $\mathrm{B} 6 \mathrm{C}^{+}$e A/J C5 três semanas após terem sido inoculados com PBS $(\mathrm{n}=5), 10^{3}$ $(n=5), 10^{5}(n=5), 10^{7}(n=5)$ ou $10^{9}(n=5)$ LPF. Os valores representam a quantidade de citocina em relação ao total de proteína presente na amostra do fígado que foi coletada. 
4.2 Resultados do modelo de infecção por seis dias com $10^{7} \mathrm{LPF}$

\subsubsection{Recuperação de leptospiras no fígado e no rim}

A análise das amostras de fígado e rim mostrou que a maioria dos camundongos de ambas as linhagens foi capaz de controlar a infecção, de forma que foram detectadas bactérias em poucas amostras de rim e de fígado após a infecção (Tabela 6).

Tabela 6 - Detecção de leptospiras no fígado e no rim de camundongos infectados com $10^{7} \mathrm{LPF}$

\begin{tabular}{ccccc}
\hline Tratamento & \multicolumn{2}{c}{ A/J C5 } & \multicolumn{2}{c}{${\text { B6 } \mathbf{C 5}^{+}}^{+}$} \\
\hline & Fígado & Rim & Fígado & Rim \\
PBS & $0 / 4$ & $0 / 4$ & $0 / 6$ & $0 / 6$ \\
$\mathbf{3}^{\circ}$ Dia & $0 / 5$ & $3 / 5$ & $2 / 6$ & $6 / 6$ \\
$\mathbf{6}^{\circ}$ Dia & $1 / 6$ & $1 / 6$ & $0 / 6$ & $0 / 6$ \\
\hline
\end{tabular}

Número de camundongos A/J C5 $\left(\mathrm{PBS} n=4 ; 3^{\circ}\right.$ dia $\mathrm{n}=6 ; 6^{\circ}$ dia $\left.\mathrm{n}=6\right)$ e $\mathrm{B} 6 \mathrm{C}^{+}\left(\mathrm{PBS} \mathrm{n}=6 ; 3^{\circ}\right.$ dia $\mathrm{n}=5 ; 6^{\circ}$ dia $\mathrm{n}=6$ ) infectados com $10^{7}$ bactérias identificados com LPF vivas no fígado e nos rins após 3 ou 6 dias de infecção.

\subsubsection{Contagem de leucócitos circulantes}

O número de leucócitos presentes na circulação periférica foi significativamente maior no $3^{\circ}$ dia da infecção nos camundongos $\mathrm{A} / \mathrm{J} \mathrm{C}^{-}$em relação ao grupo controle, permanecendo elevado até o $6^{\circ}$ dia, enquanto o número de leucócitos dos camundongos $\mathrm{B} 6 \mathrm{C}^{+}$permaneceu inalterado durante todo o experimento (Figura 13A). Inicialmente diferente entre as linhagens, o número de leucócitos circulantes tornou-se semelhante entre A/J C5 ${ }^{-}$e B6 $\mathrm{C}^{+}$ durante a infecção (Figura 13A).

Ambas as linhagens apresentaram variações semelhantes da proporção de células MN e PMN, sendo notado o aumento porcentual de células $M N$ no $3^{\circ}$ dia da infecção em relação aos animais inoculados por PBS seguido pelo retorno aos valores basais no $6^{\circ}$ dia (Figura $13)$. 
Figura 13 - Quantificação de leucócitos na circulação periférica de camundongos $\mathrm{B} 6 \mathrm{C}^{+}$e A/J C5 infectados com $10^{7} \mathrm{LPF}$

$\mathbf{A}$
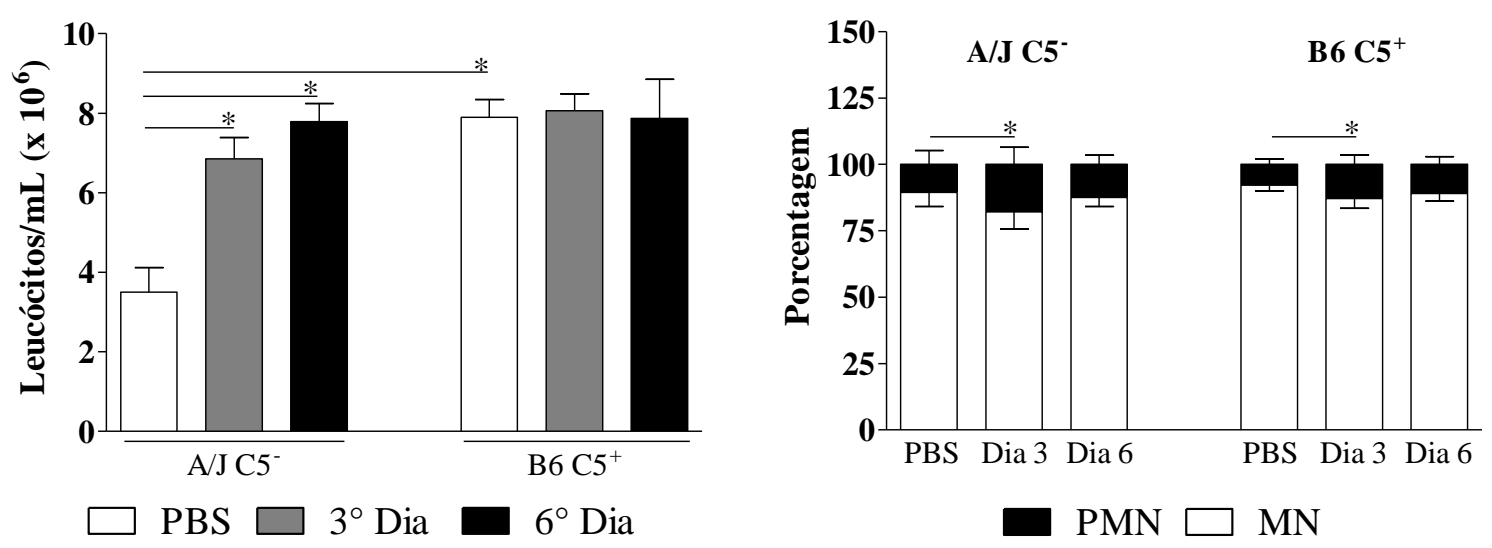

Número total de leucócitos (A) e a porcentagem de células MN (mononuclear) e PMN (polimorfonuclear) presentes na circulação periférica de camundongos A/J C5 (PBS $n=4 ; 3^{\circ}$ dia $n=6 ; 6^{\circ}$ dia $\left.n=6\right)$ e $\mathrm{B}^{\circ} \mathrm{C}^{+}(\mathrm{PBS}$ $\mathrm{n}=6 ; 3^{\circ}$ dia $\mathrm{n}=5 ; 6^{\circ}$ dia $\left.\mathrm{n}=6\right)$ infectados com $10^{7} \mathrm{LPF} . *$ corresponde à $p<0,05$.

\subsubsection{Funções hepática e renal}

Não houve alteração significativa nos níveis séricos das enzimas ALT e AST após inoculação de $10^{7}$ LPF em nenhuma das linhagens, independente do tempo de tratamento (Figura 14A e B).

Figura 14 - Avaliação da função hepática de camundongos infectados com $10^{7}$ LPF
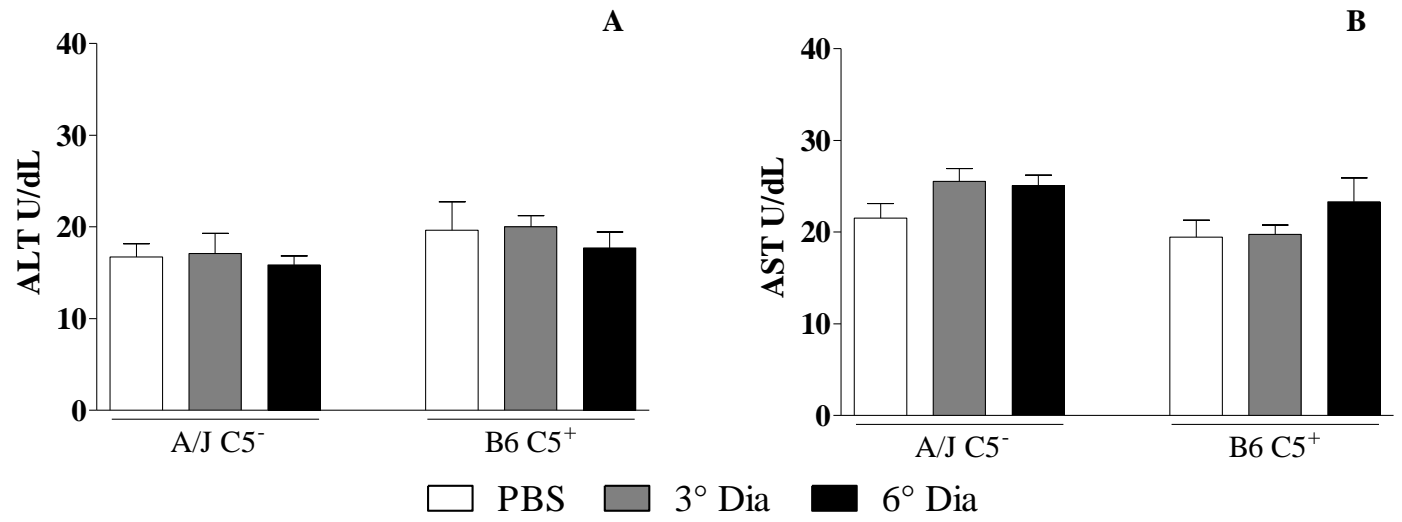

Concentração das enzimas hepáticas ALT (alanina aminotransferase - A) e AST (aspartato aminotransferase - B) de camundongos A/J C5 (PBS $n=4 ; 3^{\circ}$ dia $n=6 ; 6^{\circ}$ dia $\left.n=6\right)$ e B6 C5 $\left(\mathrm{PBS} n=6 ; 3^{\circ}\right.$ dia $n=5 ; 6^{\circ}$ dia $\left.n=6\right)$ infectados com $10^{7} \mathrm{LPF}$. 
As dosagens de ureia (Figura 15A) e ácido úrico (Figura 15B) indicaram que a concentração desses metabólitos permanece constante no soro dos camundongos durante a infecção. Foram detectadas diferenças significativas nos níveis de ureia entre A/J $\mathrm{C5}^{-}$e B6 $\mathrm{C}^{+}$no $3^{\circ}$ e no $6^{\circ}$ dia de infecção.

Figura 15 - Avaliação da função renal de camundongos infectados com $10^{7}$ LPF

A

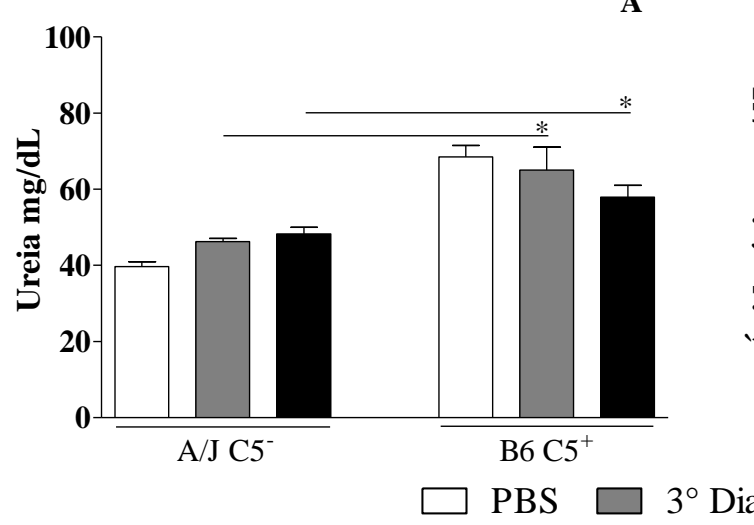

B

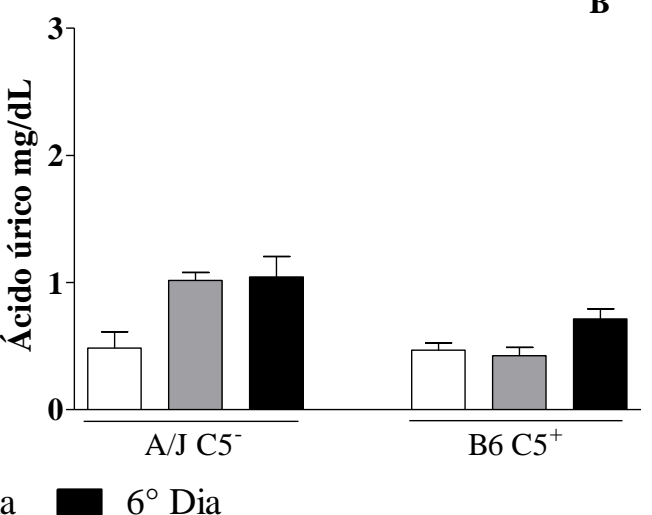

Concentração dos metabólitos ureia (A) e ácido úrico (B) de camundongos A/J C5 (PBS $n=4 ; 3^{\circ}$ dia $n=6$; $6^{\circ}$ dia $\left.\mathrm{n}=6\right)$ e $\mathrm{B} 6 \mathrm{C}^{+}\left(\mathrm{PBS} \mathrm{n}=6 ; 3^{\circ}\right.$ dia $\mathrm{n}=5 ; 6^{\circ}$ dia $\left.\mathrm{n}=6\right)$ infectados com $10^{7} \mathrm{LPF}$. * corresponde à $p<0,05$. 
4.3 Resultados do modelo de infecção de seis dias com $1,5 \times 10^{8}$ LPF

\subsubsection{Quantificação de leucócitos na circulação periférica}

O número de leucócitos periféricos nos camundongos A/J e B6 variou ao longo da infecção independentemente de C5 (Figura 16A). Camundongos da linhagem A/J do grupo controle possuem maior número de leucócitos na circulação que os animais B6, havendo redução desta quantidade no terceiro dia de infecção, quando ambas as linhagens apresentam valores semelhantes, seguida pelo restabelecimento da quantidade inicial no sexto dia de infecção, quando a quantidade de células na circulação volta a diferir entre A/J e B6. O número de leucócitos na circulação periférica da linhagem B6 permanece constante até o terceiro dia de infecção, havendo redução no número dessas células no sexto dia em relação aos valores encontrados no terceiro dia de infecção. Não foram detectadas diferenças entre os animais $\mathrm{C}^{+}$e $\mathrm{C}^{-}$considerando o fundo genético dos animais.

Curiosamente, a porcentagem de neutrófilos diminui durante a infecção, observada na linhagem B6 no terceiro dia e em camundongos A/J no sexto dia, resultando em uma diferença entre A/J e B6 apenas no terceiro dia, em um processo que aparenta ser independente de C5 (Figura 16B).

A porcentagem de monócitos na circulação é semelhante em todas as linhagens e é influenciada pela infecção, aumentando no terceiro dia e retornando aos valores iniciais no sexto dia da infecção (Figura 16C). Esta variação é independente de C5.

Embora a presença ou a ausência de C5 no organismo não tenha influenciado os parâmetros anteriores, esta proteína junto com o fundo genético de cada linhagem se mostrou importante para as alterações nas proporções de linfócitos B e T. O terceiro dia de infecção mostra um aumento significativo da porcentagem de linfócitos B sucedido pelo seu retorno aos níveis basais no sexto dia apenas em camundongos B6 $\mathrm{C}^{+}$(Figura 17). O fundo genético das linhagens também parece influenciar esse parâmetro, tendo sido encontradas diferenças entre a porcentagem de linfócitos $\mathrm{B}$ entre camundongos $\mathrm{B} 6 \mathrm{C}^{+}$e $\mathrm{A} / \mathrm{J} \mathrm{C}^{+}$no terceiro e no sexto dia de infecção (Figura 17). Entretanto, tais diferenças não foram significativas quando analisamos unicamente quanto à presença de $\mathrm{C} 5$, isto é $\mathrm{B} 6 \mathrm{C}^{+}$versus $\mathrm{B} 6 \mathrm{C}^{-}$ou $\mathrm{A} / \mathrm{J} \mathrm{C}^{+}$ versus $\mathrm{A} / \mathrm{J}$ C5 . 
Figura 16 - Contagem de leucócitos presentes na circulação periférica de camundongos A/J e B6 infectados com $1,5 \times 10^{8} \mathrm{LPF}$
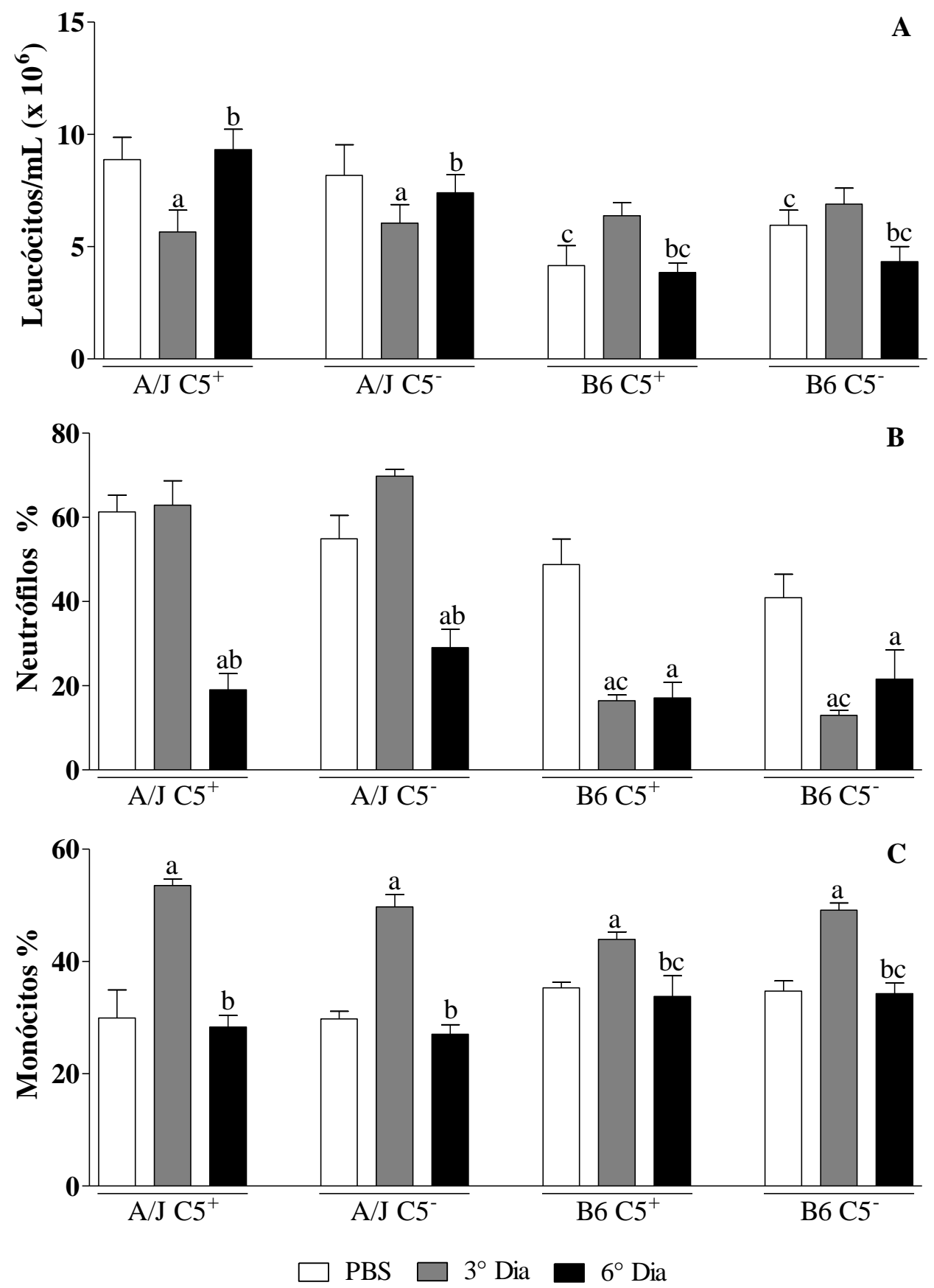

Número total de leucócitos presentes na circulação periférica (A, quantificação por microscopia óptica), neutrófilos (B) e monócitos (C) em camundongos infectados com 1,5 x 10 $0^{8}$ LPF (análise por citometria de fluxo). (A) Número de células por $\mathrm{mL}$ em camundongos $\mathrm{A} / \mathrm{J} \mathrm{C}^{+}\left(\mathrm{PBS} \mathrm{n}=5 ; 3^{\circ}\right.$ dia $\mathrm{n}=12 ; 6^{\circ}$ dia $\mathrm{n}=9$ ), A/J $\mathrm{C}^{\circ}\left(\operatorname{PBS} \mathrm{n}=4 ; 3^{\circ}\right.$ dia $\mathrm{n}=10 ; 6^{\circ}$ dia $\left.\mathrm{n}=9\right), \mathrm{B}^{\circ} \mathrm{C}^{+}\left(\mathrm{PBS} \mathrm{n}=5 ; 3^{\circ}\right.$ dia $\mathrm{n}=10 ; 6^{\circ}$ dia $\left.\mathrm{n}=10\right)$ e B6 C5$(\mathrm{PBS}$ $\mathrm{n}=5 ; 3^{\circ}$ dia $\mathrm{n}=11 ; 6^{\circ}$ dia $\mathrm{n}=10$ ). (B) Porcentagem de neutrófilos. (C) Porcentagem de monócitos. $\mathrm{B}$ e $\mathrm{C}$ correspondem a camundongos $\mathrm{A} / \mathrm{J} \mathrm{C} 5^{+}\left(\mathrm{PBS} \mathrm{n}=4 ; 3^{\circ}\right.$ dia $\mathrm{n}=12 ; 6^{\circ}$ dia $\left.\mathrm{n}=9\right), \mathrm{A} / \mathrm{J} \mathrm{C5}\left(\mathrm{PBS} \mathrm{n}=4 ; 3^{\circ}\right.$ dia $\mathrm{n}=10 ; 6^{\circ}$ dia $\left.\mathrm{n}=9\right), \mathrm{B} 6 \mathrm{C}^{+}\left(\mathrm{PBS} \mathrm{n}=5 ; 3^{\circ}\right.$ dia $\mathrm{n}=10 ; 6^{\circ}$ dia $\left.\mathrm{n}=10\right)$ e $\mathrm{B} 6 \mathrm{C}^{\circ}\left(\mathrm{PBS} \mathrm{n}=5 ; 3^{\circ}\right.$ dia $\mathrm{n}=12 ; 6^{\circ}$ dia $\mathrm{n}=10$ ). Barras brancas correspondem ao grupo PBS, barras cinzas ao $3^{\circ}$ dia e barras pretas ao $6^{\circ}$ dia de infecção. a: diferente do PBS; b: diferente do terceiro dia; $\mathbf{c}$ : diferença entre linhagens, independente de C5. As diferenças correspondem à $p<0,05$. 
Figura 17 - Porcentagem de linfócitos B na circulação periférica de camundongos infectados $\operatorname{com} 1,5 \times 10^{8} \mathrm{LPF}$

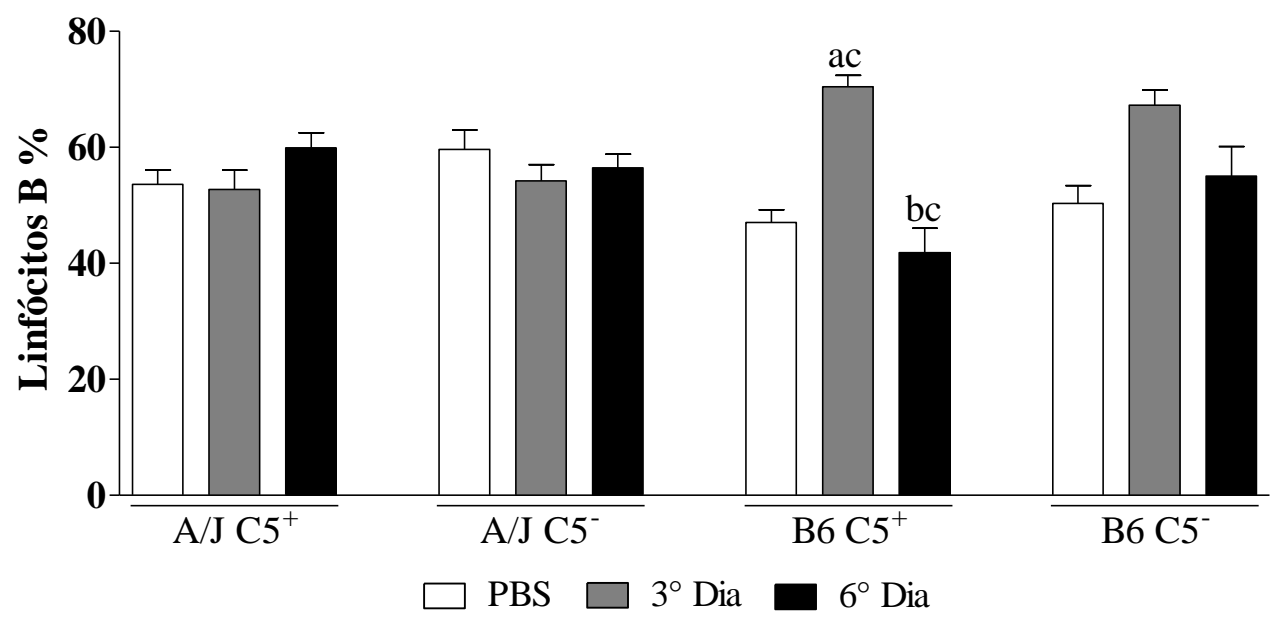

Porcentagem de linfócitos B presentes na circulação periférica de camundongos infectados com 1,5 x $10^{8} \mathrm{LPF}$ (análise por citometria de fluxo). Porcentagem de linfócitos B em camundongos A/J $\mathrm{C} 5^{+}\left(\mathrm{PBS} \mathrm{n}=4 ; 3^{\circ}\right.$ dia $\mathrm{n}=12 ; 6^{\circ}$ dia $\mathrm{n}=9$ ), A/J C5 (PBS $\mathrm{n}=4 ; 3^{\circ}$ dia $\mathrm{n}=10 ; 6^{\circ}$ dia $\left.\mathrm{n}=9\right), \mathrm{B} 6 \mathrm{C}^{+}\left(\mathrm{PBS} \mathrm{n}=5 ; 3^{\circ}\right.$ dia $\mathrm{n}=10 ; 6^{\circ}$ dia $\mathrm{n}=10)$ e $\mathrm{B} 6 \mathrm{C}^{\circ}\left(\mathrm{PBS} \mathrm{n}=5 ; 3^{\circ}\right.$ dia $\mathrm{n}=12 ; 6^{\circ}$ dia $\left.\mathrm{n}=10\right)$. Barras brancas correspondem ao grupo PBS, barras cinzas ao $3^{\circ}$ dia e barras pretas ao $6^{\circ}$ dia de infecção. a: diferente do PBS; b: diferente do terceiro dia; c: diferença entre linhagens, independente de $\mathrm{C} 5$. As diferenças correspondem à $p<0,05$.

Camundongos A/J apresentam elevação da porcentagem de linfócitos $\mathrm{T}_{\mathrm{CD}}{ }^{+}$no terceiro dia de infecção independentemente de C5, possuindo maior proporção desse tipo celular que os animais da linhagem B6 nesse período, o que é revertido no sexto dia de infecção, quando reduz a proporção de linfócitos T $\mathrm{CD}^{+}$em A/J e aumenta na linhagem B6, independentemente de C5 (Figura 18). A linhagem B6 C5 possui inicialmente uma menor porcentagem de linfócitos $\mathrm{T} \mathrm{CD}^{+}$que os animais $\mathrm{B} 6 \mathrm{C}^{+}$, o que se mantém durante a infecção (Figura 18).

A porcentagem de linfócitos $\mathrm{T} \mathrm{CD} 4^{+} \mathrm{CD} 25^{+}$(linfócitos $\mathrm{T} \mathrm{CD} 4^{+}$ativados) variou entre os animais A/J infectados e os inoculados com PBS, sendo detectada diferença significativa apenas no grupo de $\mathrm{B} 6 \mathrm{C}^{+}$eutanasiado no sexto dia e seu controle (Figura 18B). Também foram encontradas diferenças entre os animais infectados e eutanasiados no sexto dia de infecção em relação aos eutanasiados no terceiro dia na linhagem A/J C5 ${ }^{-}$e nos camundongos com fundo genético B6, independentemente da presença de C5 (Figura 18B). 
Figura 18 - Porcentagem de linfócitos $\mathrm{T} \mathrm{CD}^{+}$e linfócitos $\mathrm{T} \mathrm{CD}^{+} \mathrm{CD} 25^{+}$na circulação de camundongos infectados com $1,5 \times 10^{8} \mathrm{LPF}$
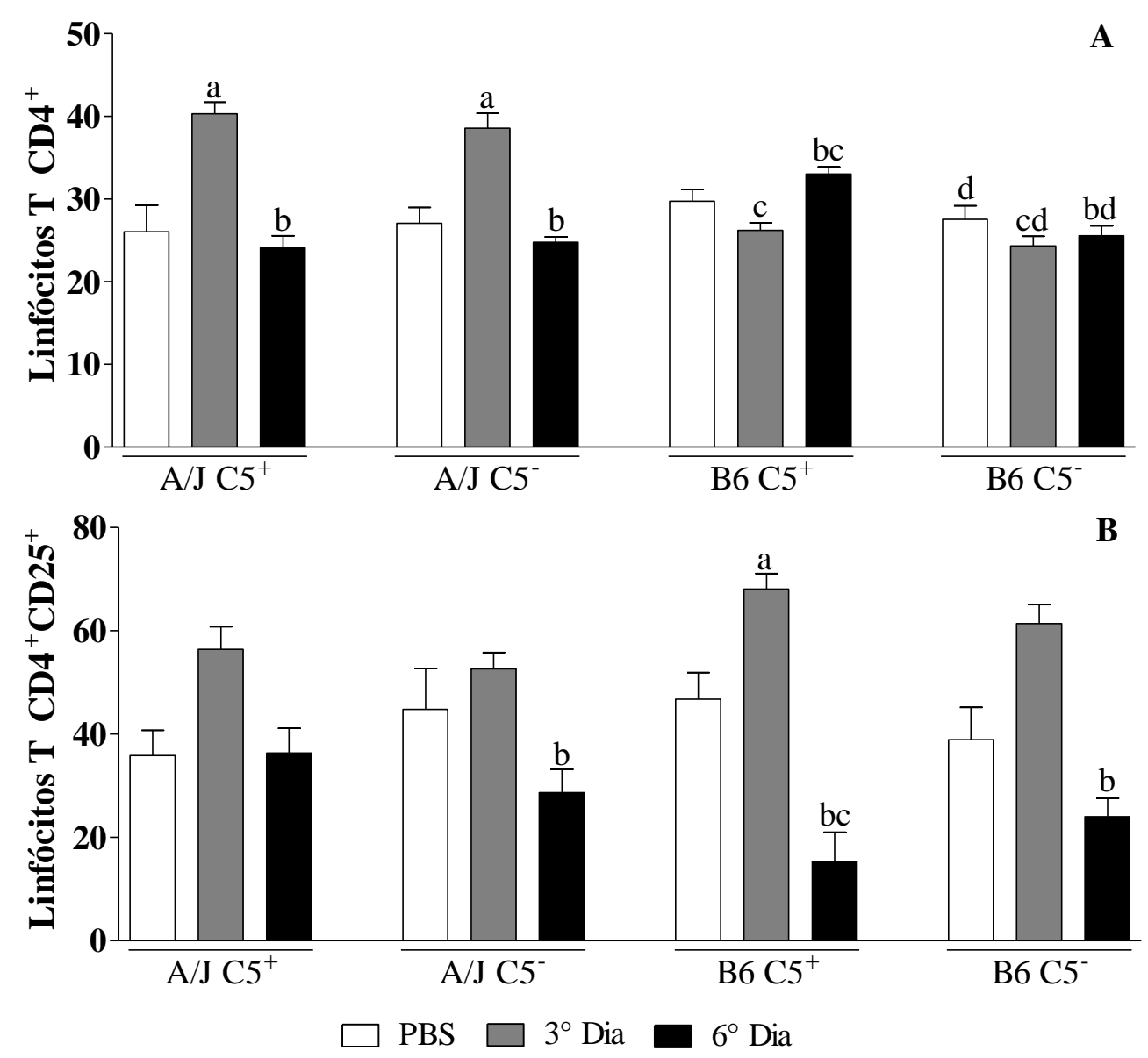

Porcentagem de linfócitos $\mathrm{T} \mathrm{CD} 4^{+}$(A) e linfócitos $\mathrm{T} \mathrm{CD} 4^{+} \mathrm{CD} 25^{+}$(B) presentes na circulação periférica de camundongos infectados com 1,5 x $10^{8}$ LPF (análise por citometria de fluxo). A e B correspondem respectivamente às porcentagens de linfócitos $\mathrm{T} \mathrm{CD} 4^{+}$e linfócitos $\mathrm{T} \mathrm{CD} 4^{+} \mathrm{CD} 25^{+}$em camundongos $\mathrm{A} / \mathrm{J} \mathrm{C} 5^{+}$

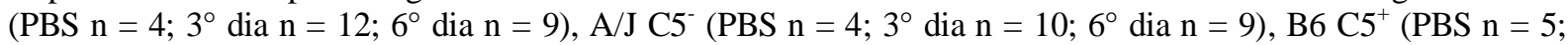
$3^{\circ}$ dia $\mathrm{n}=10 ; 6^{\circ}$ dia $\left.\mathrm{n}=10\right)$ e $\mathrm{B} 6 \mathrm{C} 5^{\circ}\left(\mathrm{PBS} \mathrm{n}=5 ; 3^{\circ}\right.$ dia $\mathrm{n}=12 ; 6^{\circ}$ dia $\left.\mathrm{n}=10\right)$. Barras brancas correspondem ao grupo PBS, barras cinzas ao $3^{\circ}$ dia e barras pretas ao $6^{\circ}$ dia de infecção. a: diferente do PBS; b: diferente do terceiro dia; c:diferença entre linhagens, independente de $\mathrm{C} 5$; $\mathbf{d}$ : diferenças entre $\mathrm{C}^{+}$e $\mathrm{C}^{-}$no mesmo fundo genético. As diferenças correspondem à $p<0,05$.

Camundongos A/J C5 $5^{-}$inoculados com PBS ou no $6^{\circ}$ dia de infecção e camundongos B6 $\mathrm{C}^{-}$infectados com $1,5 \times 10^{8} \mathrm{LPF}$ possuem menores porcentagens de linfócitos T CD8 ${ }^{+}$ circulantes que os respectivos grupos de camundongos $\mathrm{C}^{+}$(Figura 19A). A linhagem B6 apresenta queda na proporção de linfócitos $\mathrm{T} \mathrm{CD}^{+}$circulantes no terceiro dia de infecção seguido pelo restabelecimento dos valores iniciais no sexto dia, enquanto $\mathrm{A} / \mathrm{J}$ tem redução na porcentagem dessas células na circulação apenas no sexto dia de infecção. Essa combinação de resultados faz com que ambas as linhagens, de forma independente de C5, tenham diferença da porcentagem de linfócitos $\mathrm{T} \mathrm{CD}^{+}$no terceiro e no sexto dia de infecção (Figura 19A). 
A porcentagem de linfócitos $\mathrm{T} \mathrm{CD}^{+} \mathrm{CD} 25^{+}$(linfócitos $\mathrm{T} \mathrm{CD}^{+}$ativados) na circulação tende a reduzir durante a infecção, ocorrendo mais rapidamente nos animais deficientes de C5 (Figura 19B). Essa diferença de tempo resulta na diferença da porcentagem de linfócitos $T$ $\mathrm{CD}^{+}$ativados entre animais $\mathrm{C}^{+}$e $\mathrm{C}^{-}$no terceiro dia de infecção.

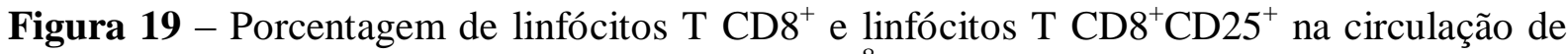
camundongos infectados com $1,5 \times 10^{8} \mathrm{LPF}$
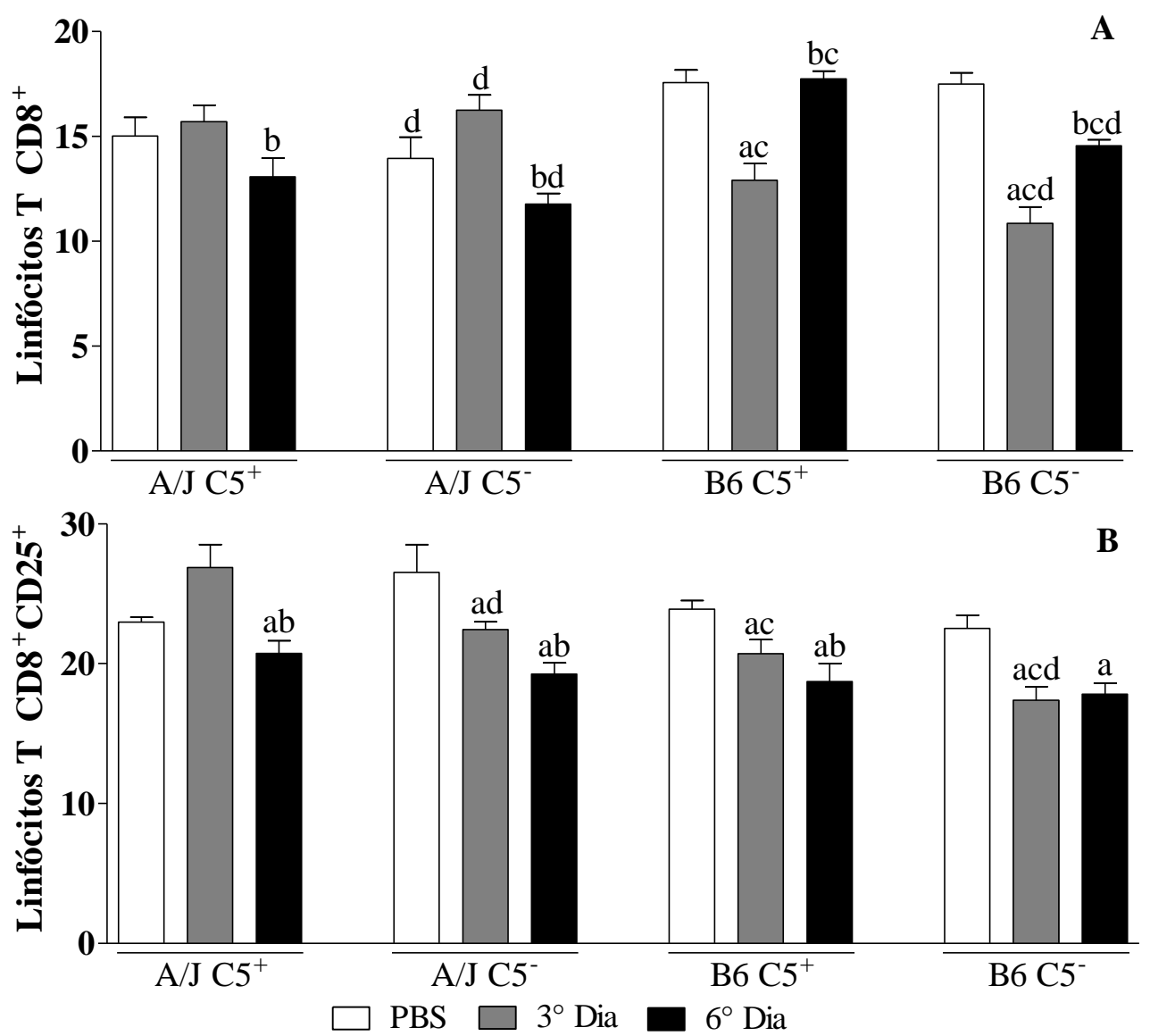

Porcentagem de linfócitos $\mathrm{T} \mathrm{CD}^{+}$(A) e linfócitos $\mathrm{T} C D 8^{+} \mathrm{CD} 25^{+}$(B) presentes na circulação periférica de camundongos infectados com 1,5 x $10^{8} \mathrm{LPF}$ (análise por citometria de fluxo). A e B correspondem respectivamente às porcentagens de linfócitos $\mathrm{T} \mathrm{CD} 8^{+}$e linfócitos $\mathrm{T} \mathrm{CD}^{+} \mathrm{CD} 25^{+}$em camundongos $\mathrm{A} / \mathrm{J} \mathrm{C} 5^{+}$ $\left(\mathrm{PBS} n=4 ; 3^{\circ}\right.$ dia $\mathrm{n}=12 ; 6^{\circ}$ dia $\left.\mathrm{n}=9\right), \mathrm{A} / \mathrm{J} \mathrm{C5}^{\circ}\left(\mathrm{PBS} \mathrm{n}=4 ; 3^{\circ}\right.$ dia $\mathrm{n}=10 ; 6^{\circ}$ dia $\left.\mathrm{n}=9\right), \mathrm{B}^{\circ} \mathrm{C}^{+}(\mathrm{PBS} \mathrm{n}=5$; $3^{\circ}$ dia $n=10 ; 6^{\circ}$ dia $\left.n=10\right)$ e B6 C5 $\left(\right.$ PBS $n=5 ; 3^{\circ}$ dia $n=12 ; 6^{\circ}$ dia $\left.n=10\right)$. Barras brancas correspondem ao grupo PBS, barras cinzas ao $3^{\circ}$ dia e barras pretas ao $6^{\circ}$ dia de infecção. a: diferente do PBS; b: diferente do terceiro dia; c: diferença entre linhagens, independente de $\mathrm{C} 5$; $\mathbf{d}$ : diferenças entre $\mathrm{C}^{+}{ }^{+}$e $\mathrm{C}^{-}$no mesmo fundo genético. As diferenças correspondem à $p<0,05$.

\subsubsection{Desenvolvimento de esplenomegalia}

Sabendo que a leptospira é bastante encontrada na circulação no início da infecção, acompanhamos o desenvolvimento de esplenomegalia nos camundongos infectados com LPF 
(Figura 20). Nossos resultados mostraram aumento da massa proporcional do baço em relação à massa do organismo em todas as linhagens. Esse crescimento foi mais intenso nos camundongos B6 no terceiro dia de infecção, com regressão da massa do baço no sexto dia (Figura 20). A linhagem $\mathrm{A} / \mathrm{J}$ teve um crescimento do baço menos intenso, mas que se manteve até o sexto dia da infecção (Figura 20). Essas variações foram sempre independentes de C5.

Figura 20 - Desenvolvimento de esplenomegalia devido à infecção com 1,5 x $10^{8}$ LPF

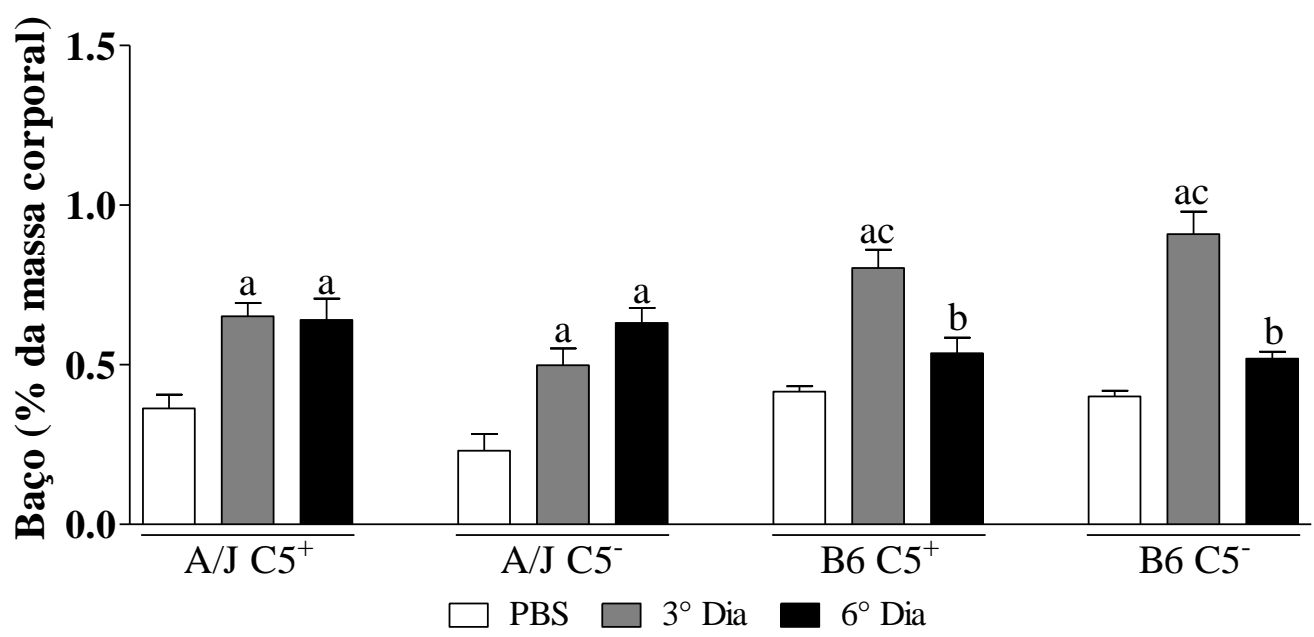

Foi calculada a massa proporcional do baço em relação à massa de cada camundongo infectado com $1,5 \times 10^{8} \mathrm{LPF}$ no momento de eutanásia. A/J $\mathrm{C}^{+}\left(\mathrm{PBS} \mathrm{n}=5 ; 3^{\circ}\right.$ dia $\mathrm{n}=12 ; 6^{\circ}$ dia $\left.\mathrm{n}=9\right)$ ), A/J C5 $(\mathrm{PBS} \mathrm{n}=4$; $3^{\circ}$ dia $n=10 ; 6^{\circ}$ dia $\left.n=9\right)$, B6 C $5^{+}\left(\right.$PBS $n=5 ; 3^{\circ}$ dia $n=10 ; 6^{\circ}$ dia $\left.n=10\right)$ e B6 C5 $\left(\right.$ PBS $n=5 ; 3^{\circ}$ dia $n=12$; $6^{\circ}$ dia $n=10$ ). Barras brancas correspondem ao grupo PBS, barras cinzas ao $3^{\circ}$ dia e barras pretas ao $6^{\circ}$ dia de infecção. a: diferente do PBS; b: diferente do terceiro dia; c:diferença entre linhagens, independente de C5. As diferenças correspondem à $p<0,05$.

\subsubsection{Análise das funções hepática e renal}

A linhagem B6 não apresenta variação significativa dos níveis de ALT devido à infecção, sendo esse efeito observado tanto em animais $\mathrm{C}^{+}$quanto em C5- (Figura 21). Contudo, houve aumento significativo da concentração sérica de ALT na linhagem A/J independente da presença ou da ausência de C5 e de AST nos camundongos A/J C5 ${ }^{+}$no terceiro dia de infecção, sugerindo dano hepático nesses animais (Figura 21A e B). A linhagem congênica B6 $\mathrm{C5}^{-}$apresentou redução dos níveis séricos de AST no sexto dia em relação ao terceiro dia de infecção, embora as concentrações dessa enzima tenham permanecido semelhantes ao observado nos animais controle (Figura 21B). 
Figura 21 - Avaliação da função hepática de camundongos infectados com 1,5 x $10^{8}$ LPF
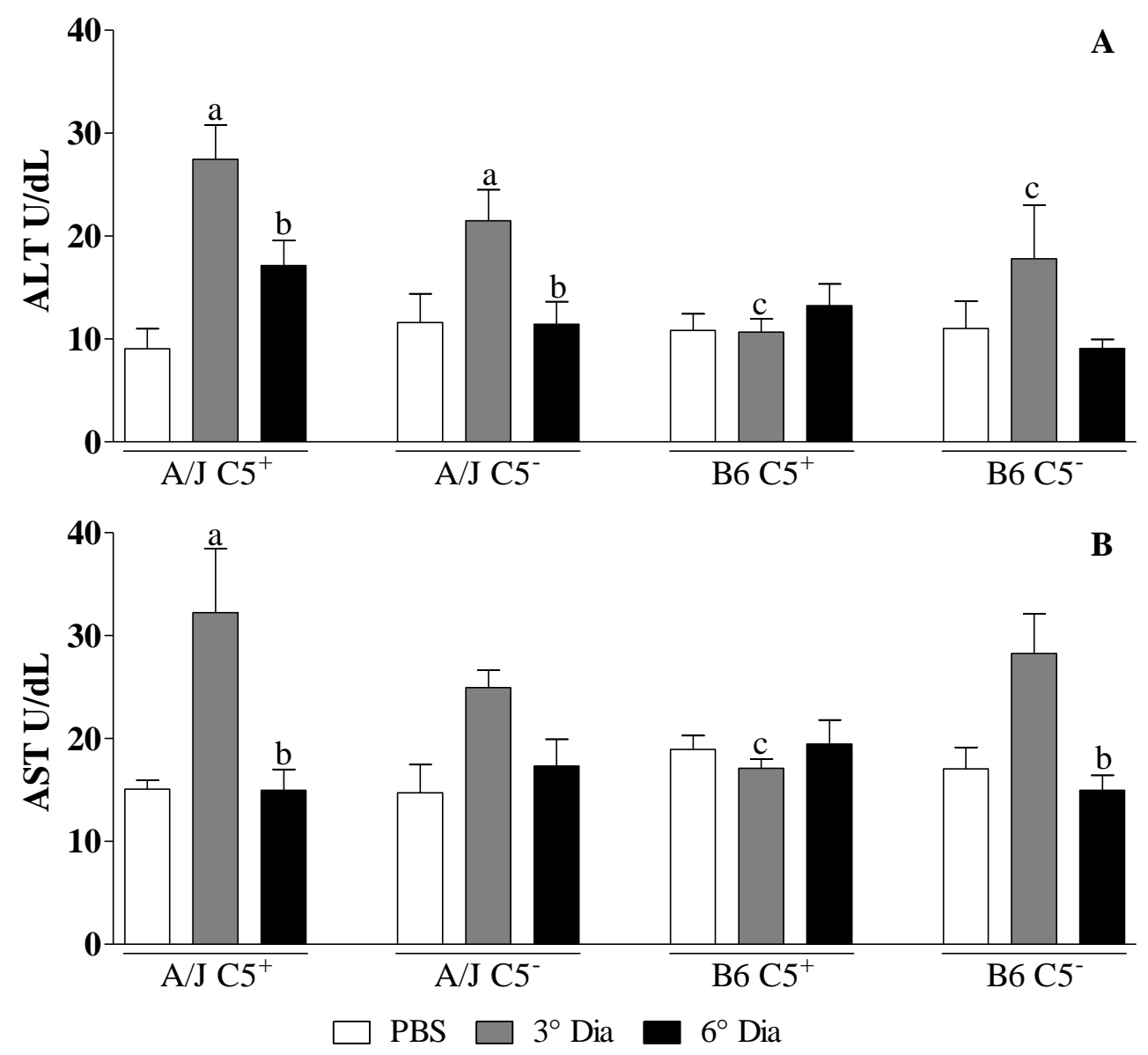

As concentrações séricas de ALT (A) e AST (B) foram utilizadas como indicadores indiretos da integridade hepática de camundongos infectados com $1,5 \times 10^{8} \mathrm{LPF}$. (A e B) A/J C5 $\left(\mathrm{PBS} \mathrm{n}=5 ; 3^{\circ}\right.$ dia $\mathrm{n}=12 ; 6^{\circ}$ dia $\mathrm{n}=9), \mathrm{A} / \mathrm{J} \mathrm{C5}^{-}\left(\mathrm{PBS} \mathrm{n}=4 ; 3^{\circ}\right.$ dia $\mathrm{n}=10 ; 6^{\circ}$ dia $\left.\mathrm{n}=9\right), \mathrm{B} 6 \mathrm{C}^{+}\left(\mathrm{PBS} \mathrm{n}=5 ; 3^{\circ}\right.$ dia $\mathrm{n}=10 ; 6^{\circ}$ dia $\left.\mathrm{n}=9\right)$ e B6 C5 $\left(\mathrm{PBS} \mathrm{n}=5 ; 3^{\circ}\right.$ dia $\mathrm{n}=11 ; 6^{\circ}$ dia $\mathrm{n}=10$ ). Barras brancas correspondem ao grupo PBS, barras cinzas ao $3^{\circ}$ dia $\mathrm{e}$ barras pretas ao $6^{\circ}$ dia de infecção. a: diferente do PBS; b: diferente do terceiro dia; c: diferença entre linhagens, independente de $\mathrm{C} 5$. As diferenças correspondem à $p<0,05$.

Embora camundongos B6 possuam maiores níveis de ureia no soro que camundongos $\mathrm{A} / \mathrm{J}$, o comportamento desse parâmetro foi igual em todas as linhagens, havendo redução da sua concentração no terceiro dia seguido pela recuperação parcial das concentrações iniciais no sexto dia (Figura 22A). Também não houve diferença devido ao animal ser C5 normal ou C5 deficiente.

A concentração de ácido úrico não foi afetada pela presença ou ausência de C5 nos camundongos, mas teve comportamento distinto entre as linhagens A/J e B6 (Figura 22B). Camundongos B6 tiveram níveis aumentados no sexto dia de infecção, enquanto camundongos $\mathrm{A} / \mathrm{J}$ apresentaram queda da concentração desse parâmetro no sexto dia em relação ao terceiro dia. 
Figura 22 - Avaliação da função renal de camundongos infectados com 1,5 x $10^{8} \mathrm{LPF}$
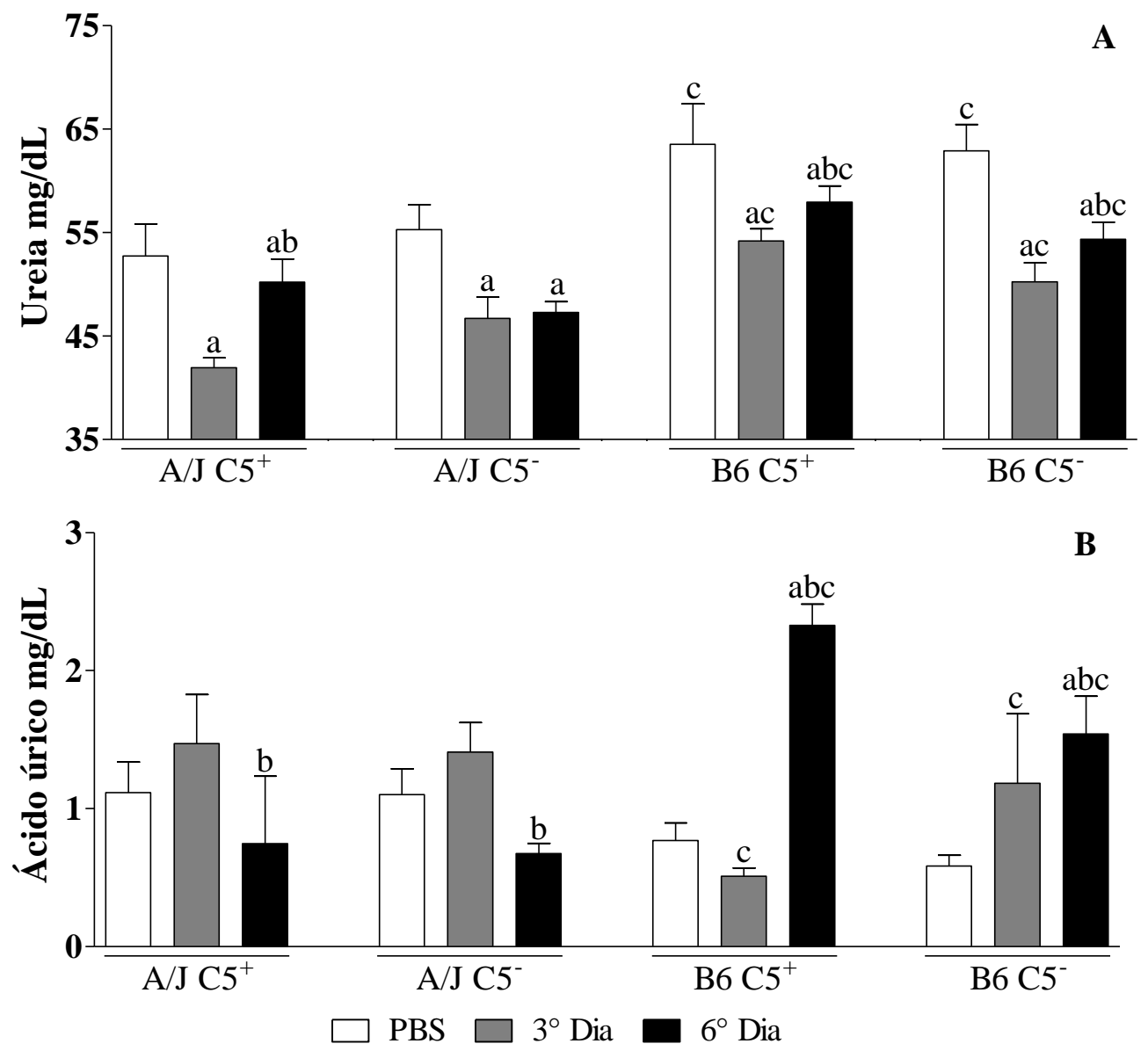

As concentrações séricas de ureia (A) e ácido úrico (B) foram utilizadas como indicadores de função renal de camundongos infectados com 1,5 x $10^{8} \mathrm{LPF}$. (A e B) A/J C5 $5^{+} \mathrm{PBS} \mathrm{n}=5 ; 3^{\circ}$ dia $\mathrm{n}=12 ; 6^{\circ}$ dia $\mathrm{n}=9$ ), A/J C5 $\left(\operatorname{PBS} n=4 ; 3^{\circ}\right.$ dia $n=10 ; 6^{\circ}$ dia $\left.n=9\right), \mathrm{B}^{\circ} \mathrm{C}^{+}\left(\mathrm{PBS} \mathrm{n}=5 ; 3^{\circ}\right.$ dia $\mathrm{n}=10 ; 6^{\circ}$ dia $\left.\mathrm{n}=10\right)$ e B6 C5 $(\mathrm{PBS} \mathrm{n}=5$; $3^{\circ}$ dia $\mathrm{n}=11 ; 6^{\circ}$ dia $\mathrm{n}=10$ ). Barras brancas correspondem ao grupo PBS, barras cinzas ao $3^{\circ}$ dia e barras pretas ao $6^{\circ}$ dia de infecção. a: diferente do PBS; b: diferente do terceiro dia; c: diferença entre linhagens, independente de $\mathrm{C} 5$. As diferenças correspondem à $p<0,05$.

\subsubsection{Concentração de citocinas no soro durante infecção com $1,5 \times 10^{8} \mathrm{LPF}$}

As concentrações de TNF- $\alpha$, IFN- $\gamma$ e IL-6 (Figura 23A-C) estão, independentemente de C5, elevadas na linhagem A/J apenas no terceiro dia da infecção, sendo maiores que os valores obtidos nos animais controle, animais infectados eutanasiados nos sexto dia e camundongos B6, onde as concentrações dessas citocinas permanecem constantes. A presença de C5 não influenciou a expressão dessas citocinas no soro durante a infecção em nenhuma das linhagens empregadas.

Os níveis séricos de IL-10, MCP-1 e IL-12p70 (Figura 24A-C) foram indetectáveis na maior parte das amostras, não sendo possível analisar estatisticamente as diferenças durante a 
infecção. No entanto, não existem diferenças significativas nos níveis dessas citocinas entre os grupos onde elas puderam ser detectadas.

Figura 23 - Concentração de citocinas no soro de camundongos infectados com $1,5 \times 10^{8} \mathrm{LPF}$
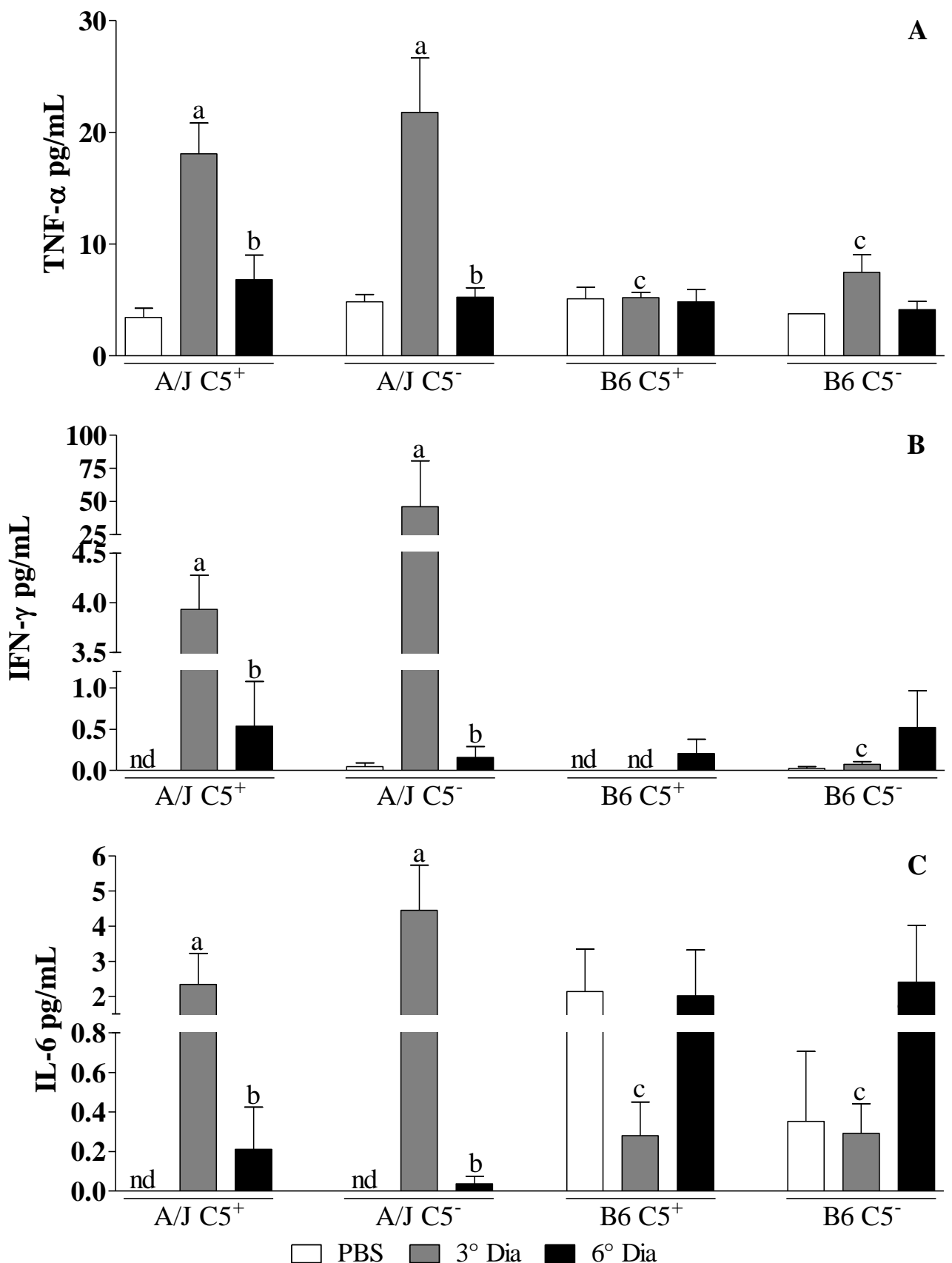

Variação das concentrações de citocinas próinflamatórias no soro de camundongos infectados com $1,5 \times 10^{8}$ LPF. (A) TNF- $\alpha$. (B) IFN- $\gamma$. (C) IL-6. A $/ \mathrm{J} \mathrm{C5} 5^{+}\left(\mathrm{PBS} \mathrm{n}=3 ; 3^{\circ}\right.$ dia $\mathrm{n}=5 ; 6^{\circ}$ dia $\left.\mathrm{n}=5\right), \mathrm{A} / \mathrm{J} \mathrm{C} 5^{-}\left(\mathrm{PBS} \mathrm{n}=3 ; 3^{\circ}\right.$ dia $\mathrm{n}=5 ; 6^{\circ}$ dia $\left.\mathrm{n}=5\right)$, $\mathrm{B} 6 \mathrm{C}^{+}\left(\mathrm{PBS} \mathrm{n}=3 ; 3^{\circ}\right.$ dia $\mathrm{n}=5 ; 6^{\circ}$ dia $\left.\mathrm{n}=5\right)$ e $\mathrm{B}^{\circ} \mathrm{C}^{\circ}\left(\mathrm{PBS} \mathrm{n}=3 ; 3^{\circ}\right.$ dia $\mathrm{n}=5 ; 6^{\circ}$ dia $\mathrm{n}=5$ ). Barras brancas correspondem ao grupo PBS, barras cinzas ao $3^{\circ}$ dia e barras pretas ao $6^{\circ}$ dia de infecção. a: diferente do PBS; b: diferente do terceiro dia; c: diferença entre linhagens, independente de C5; nd: não detectado. As diferenças correspondem à $p<0,05$. 
Figura 24 - Concentração de citocinas no soro de camundongos infectados com $1,5 \times 10^{8} \mathrm{LPF}$
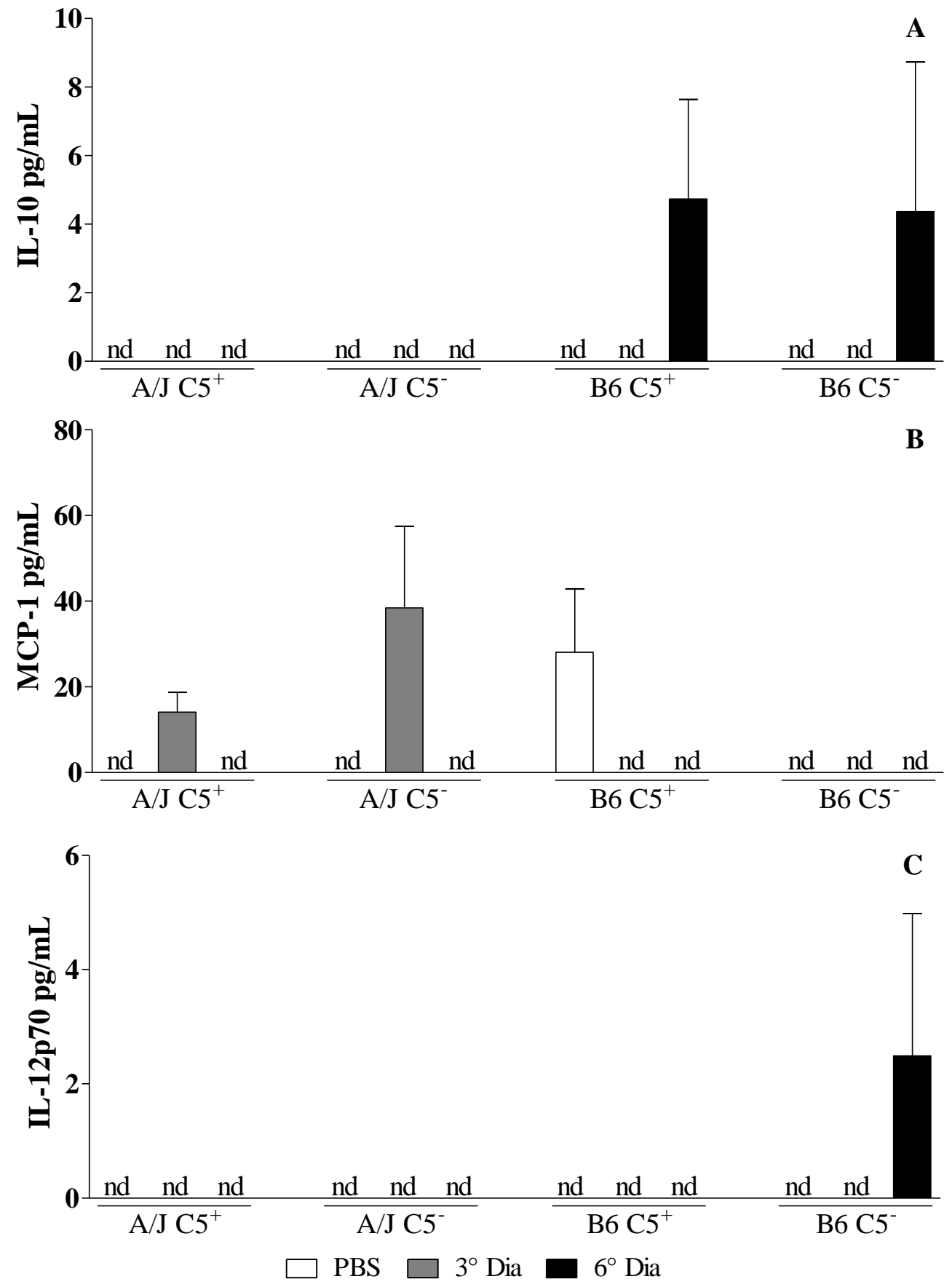

Variação das concentrações de citocinas pró e anti-inflamatórias no soro de camundongos infectados com $1,5 \times 10^{8}$ LPF. (A) IL-10. (B) MCP-1. (C) IL-12p70. A/J C5 (PBS $\mathrm{n}=3 ; 3^{\circ}$ dia $\mathrm{n}=5 ; 6^{\circ}$ dia $\mathrm{n}=5$ ), A/J C5 $\left(\right.$ PBS $n=3 ; 3^{\circ}$ dia $n=5 ; 6^{\circ}$ dia $\left.n=5\right), \mathrm{B}^{\circ} \mathrm{C}^{+}\left(\mathrm{PBS} \mathrm{n}=3 ; 3^{\circ}\right.$ dia $\mathrm{n}=5 ; 6^{\circ}$ dia $\left.\mathrm{n}=5\right)$ e B6 $\mathrm{C5}^{-}(\mathrm{PBS} \mathrm{n}=3$; $3^{\circ}$ dia $n=5 ; 6^{\circ}$ dia $n=5$ ). Barras brancas correspondem ao grupo PBS, barras cinzas ao $3^{\circ}$ dia e barras pretas ao $6^{\circ}$ dia de infecção. nd: não detectado. 
4.3.5 Concentração de citocinas no fígado durante infecção com $1,5 \times 10^{8} \mathrm{LPF}$

A ausência da proteína C5 causou variações nos níveis de IL-10 (Figura 25C), IL-1 $\beta$, IL-12p40 e IL-12p70 (Figura 26A-C) no $6^{\circ}$ dia de infecção, as quais estavam em menor concentração no fígado dos animais C5 deficientes, independente do fundo genético.

Camundongos B6 apresentam maiores concentrações hepáticas de IL-6 e TNF e menores concentrações de IL-12p70 que camundongos A/J, independentemente de C5 e da infecção (Figura 25A e B), enquanto camundongos B6 $\mathrm{C5}^{-}$apresentam maiores níveis de IL-10 e IL-12p40 que camundongos A/J C5 ${ }^{-}$(Figura 25C). Também foi observada a redução dos níveis de IL-6 a partir do $3^{\circ}$ dia de infecção em todos os grupos analisados, quando comparados com o controle PBS (Figura 25B) e de IL-1 $\beta$ e IL-12p40 no $6^{\circ}$ dia de infecção apenas nos camundongos C5 deficientes (Figura 26A-C), também quando comparados aos respectivos grupos controle, independentemente da linhagem. 
Figura 25 - Concentração de TNF, IL-6 e IL-10 no fígado de camundongos infectados com $1,5 \times 10^{8} \mathrm{LPF}$
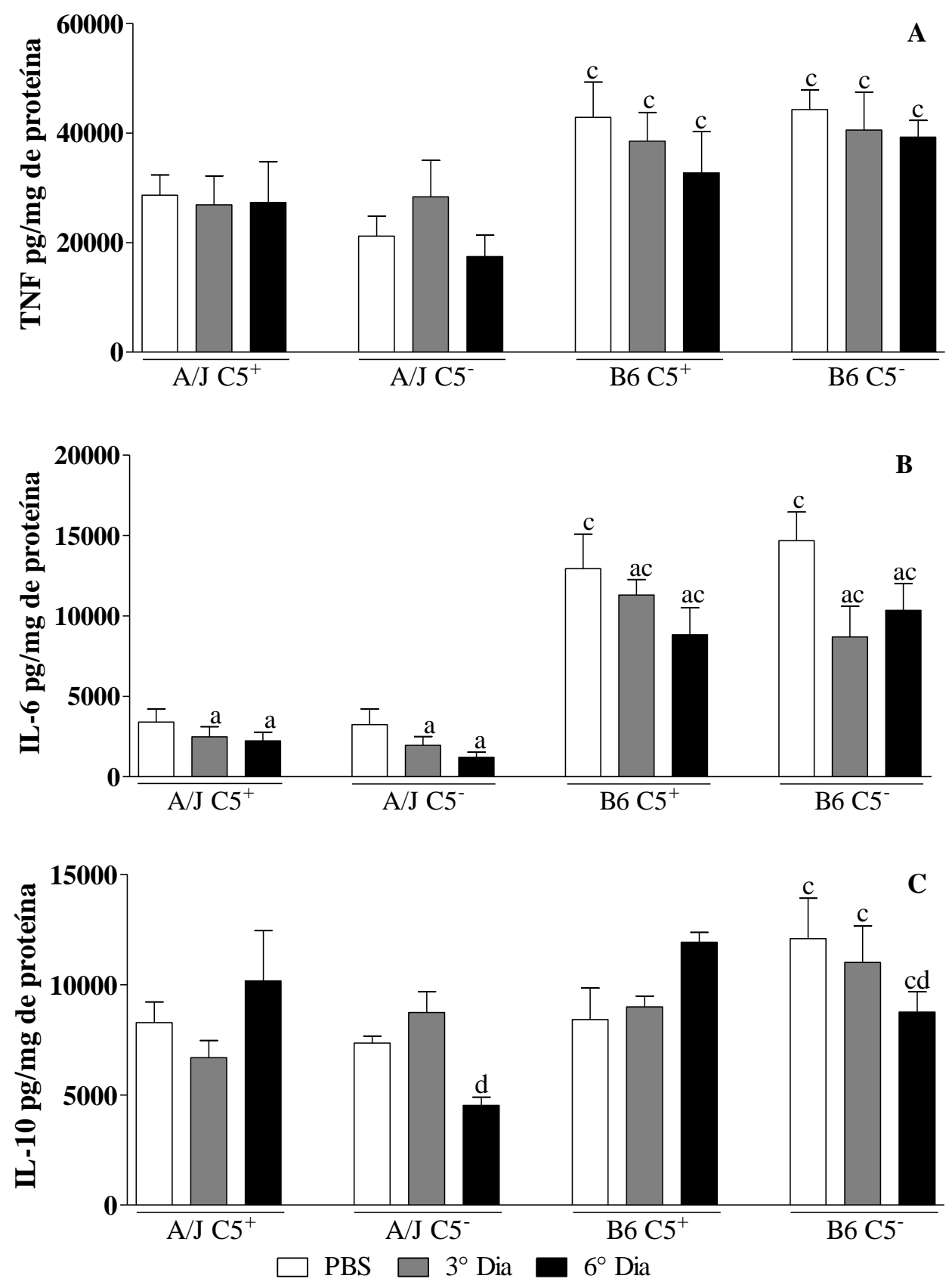

Variação das concentrações de citocinas pró e anti-inflamatórias no fígado de camundongos infectados com $1,5 \times 10^{8}$ LPF. (A) TNF. (B) IL-6. (C) IL-10. A/J C5 ${ }^{+}$(PBS $n=5 ; 3^{\circ}$ dia $n=12 ; 6^{\circ}$ dia $n=9$ ), A/J C5 (PBS $\mathrm{n}=4 ; 3^{\circ}$ dia $\mathrm{n}=10 ; 6^{\circ}$ dia $\left.\mathrm{n}=9\right)$, B6 $\mathrm{C}^{+}\left(\mathrm{PBS} \mathrm{n}=5 ; 3^{\circ}\right.$ dia $\mathrm{n}=10 ; 6^{\circ}$ dia $\left.\mathrm{n}=10\right)$ e B6 C5 $\left(\mathrm{PBS} \mathrm{n}=5 ; 3^{\circ}\right.$ dia $\mathrm{n}=12 ; 6^{\circ}$ dia $\mathrm{n}=10$ ). Barras brancas correspondem ao grupo PBS, barras cinzas ao $3^{\circ}$ dia e barras pretas ao $6^{\circ}$ dia de infecção. a: diferente do PBS; c: diferença entre linhagens, independente de $\mathrm{C} 5$; d: diferenças entre $\mathrm{C}^{+}$e $\mathrm{C}^{-}$no mesmo fundo genético. As diferenças correspondem à $p<0,05$. 
Figura 26 - Concentração de IL-1 $\beta$, IL-12p40 e IL-12p70 no fígado de camundongos infectados com $1,5 \times 10^{8} \mathrm{LPF}$
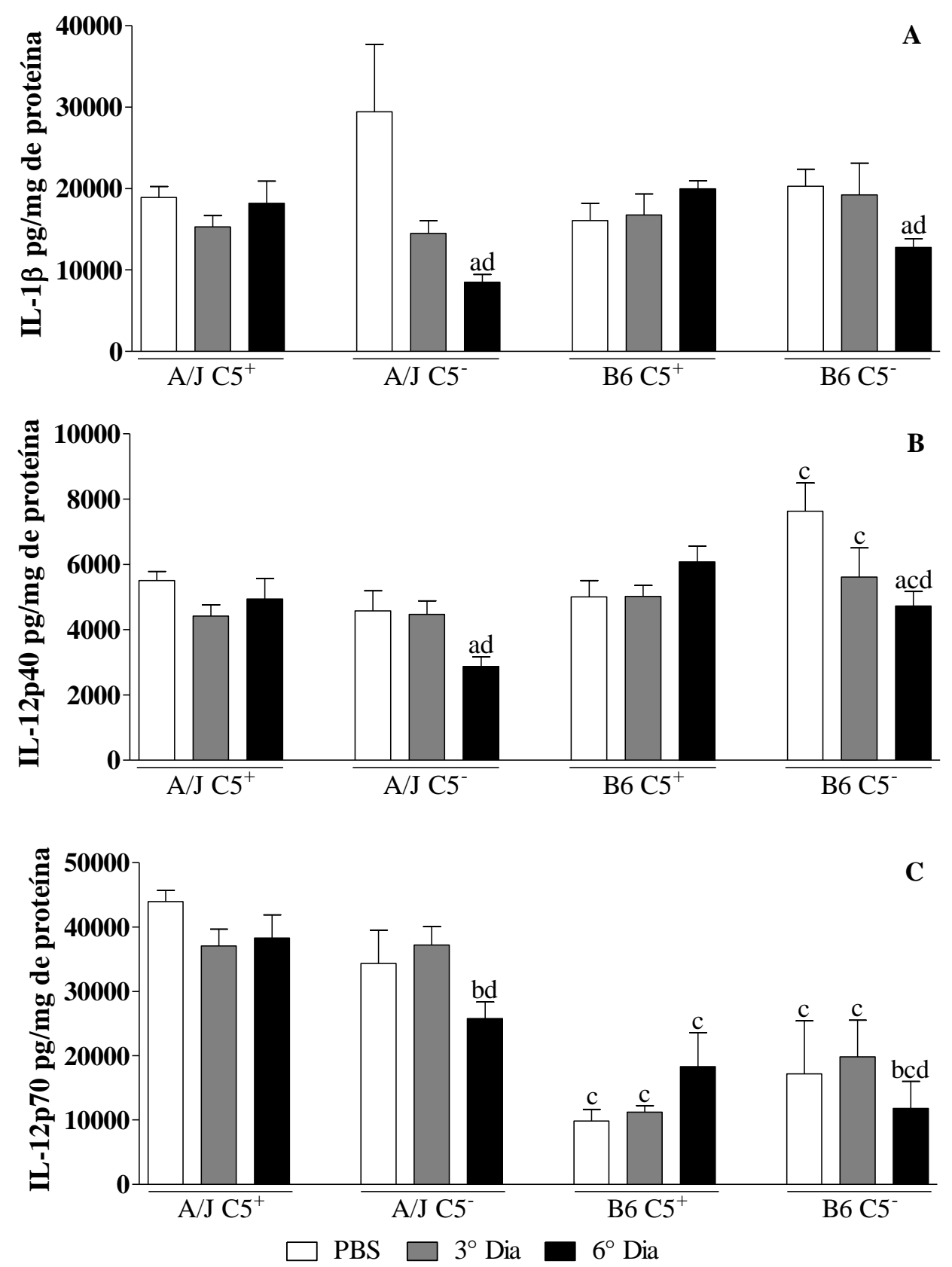

Variação das concentrações de citocinas no fígado de camundongos infectados com $1,5 \times 10^{8}$ LPF. (A) IL-1 $\beta$. (B) IL-12p40. (C) IL-12p70. A/J C5 ${ }^{+}$(PBS $n=5 ; 3^{\circ}$ dia $n=12 ; 6^{\circ}$ dia $n=9$ ), A/J C5 (PBS $n=4 ; 3^{\circ}$ dia $n=10$; $\left.6^{\circ} \operatorname{dia} n=9\right),{\mathrm{B} 6 ~ C 5^{+}}^{(\mathrm{PBS} n}=5 ; 3^{\circ}$ dia $n=10 ; 6^{\circ}$ dia $\left.n=10\right)$ e B6 C5 $\left(\operatorname{PBS} \mathrm{n}=5 ; 3^{\circ}\right.$ dia $n=12 ; 6^{\circ}$ dia $\left.n=10\right)$. Barras brancas correspondem ao grupo PBS, barras cinzas ao $3^{\circ}$ dia e barras pretas ao $6^{\circ}$ dia de infecção. a: diferente do PBS; b: diferente do terceiro dia; $\mathbf{c}$ : diferença entre linhagens, independente de C5; d: diferenças entre $\mathrm{C}^{+}$e $\mathrm{C}^{-}$no mesmo fundo genético. As diferenças correspondem à $p<0,05$.

\subsubsection{Concentração de citocinas no rim durante infecção com $1,5 \times 10^{8} \mathrm{LPF}$}

Foram observadas diferenças significativas entre animais $\mathrm{C5}^{+}$e $\mathrm{C5}^{-}$nas concentrações de TNF e IL-6 (Figura 27A e B) independente da linhagem, e de IL-10 (Figura 27C), 
IL-12p40 e IL-12p70 (Figura 28B e C) entre animais B6 $\mathrm{C5}^{+}$e B6 C5: Camundongos A/J C5 ${ }^{-}$possuem maiores concentrações de TNF e IL-6 que A/J C5 ${ }^{+}$(Figura 27A e B), enquanto animais B6 $\mathrm{C}^{-}$possuem sempre menores níveis de citocinas, com exceção de IL$1 \beta$, que animais B6 C5 ${ }^{+}$(Figuras 27 e 28).

Figura 27 - Concentração de TNF, IL-6 e IL-10 no rim de camundongos infectados com $1,5 \times 10^{8} \mathrm{LPF}$
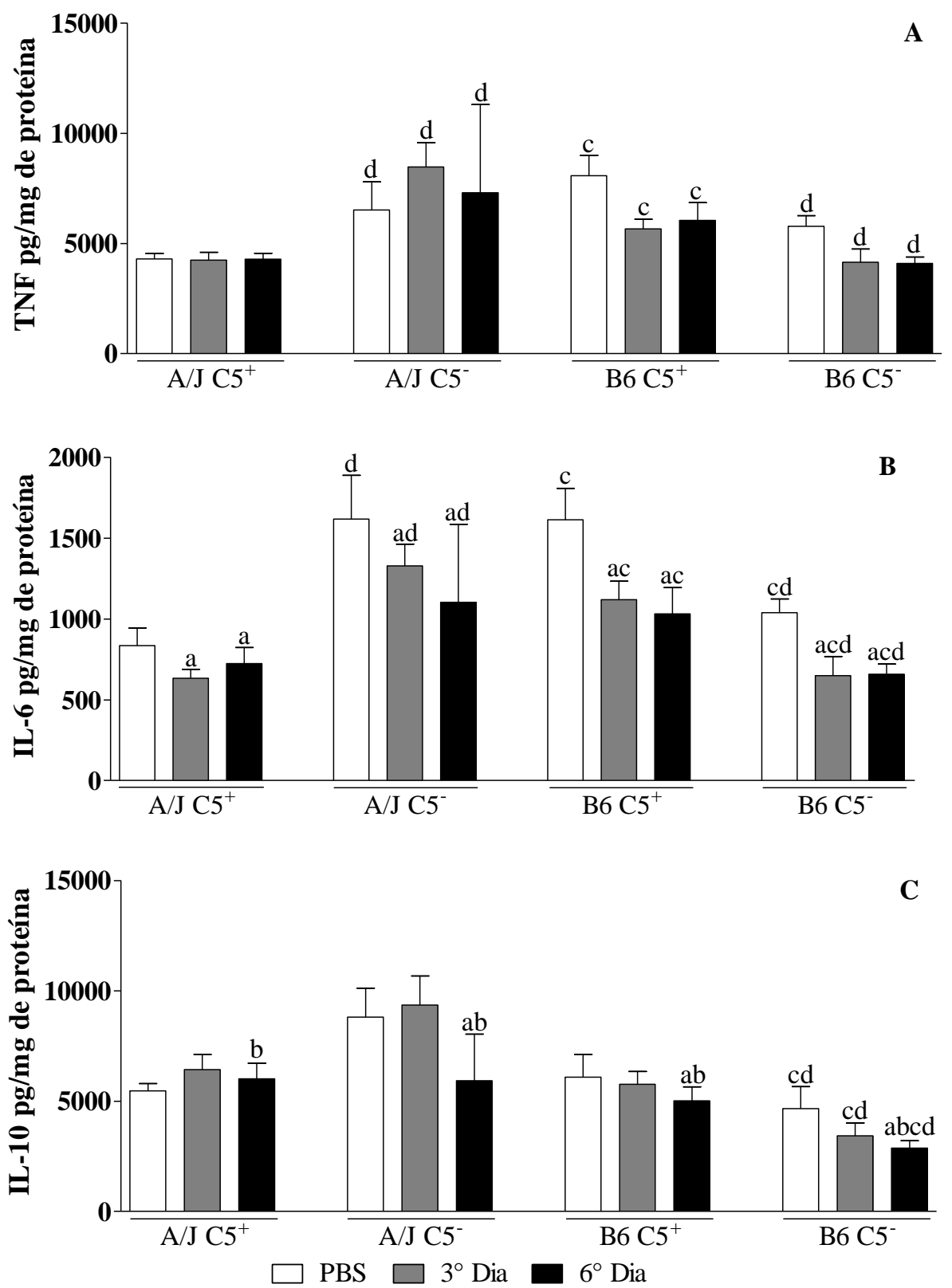

Variação das concentrações de citocinas pró e anti-inflamatórias no rim de camundongos infectados com $1,5 \times 10^{8}$ LPF. (A) TNF. (B) IL-6. (C) IL-10. A/J C5 ${ }^{+}$(PBS $n=5 ; 3^{\circ}$ dia $n=12 ; 6^{\circ}$ dia $n=9$ ), A/J C5 (PBS $\mathrm{n}=4 ; 3^{\circ}$ dia $\mathrm{n}=10 ; 6^{\circ}$ dia $\left.\mathrm{n}=9\right), \mathrm{B}^{\mathrm{C} C 5^{+}}\left(\mathrm{PBS} \mathrm{n}=5 ; 3^{\circ}\right.$ dia $\mathrm{n}=10 ; 6^{\circ}$ dia $\left.\mathrm{n}=10\right)$ e B6 C5 $\left(\mathrm{PBS} \mathrm{n}=5 ; 3^{\circ}\right.$ dia $\mathrm{n}=11 ; 6^{\circ}$ dia $\mathrm{n}=10$ ). Barras brancas correspondem ao grupo PBS, barras cinzas ao $3^{\circ}$ dia e barras pretas ao $6^{\circ}$ dia de infecção. a: diferente do PBS; b: diferente do terceiro dia; c: diferença entre linhagens, independente de $\mathrm{C} 5$; d: diferenças entre $\mathrm{C}^{+}$e $\mathrm{C}^{-}$no mesmo fundo genético. As diferenças correspondem à $p<0,05$. 
Figura 28 - Concentração de IL-1 $\beta$, IL-12p40 e IL-12p70 no rim de camundongos infectados com $1,5 \times 10^{8} \mathrm{LPF}$
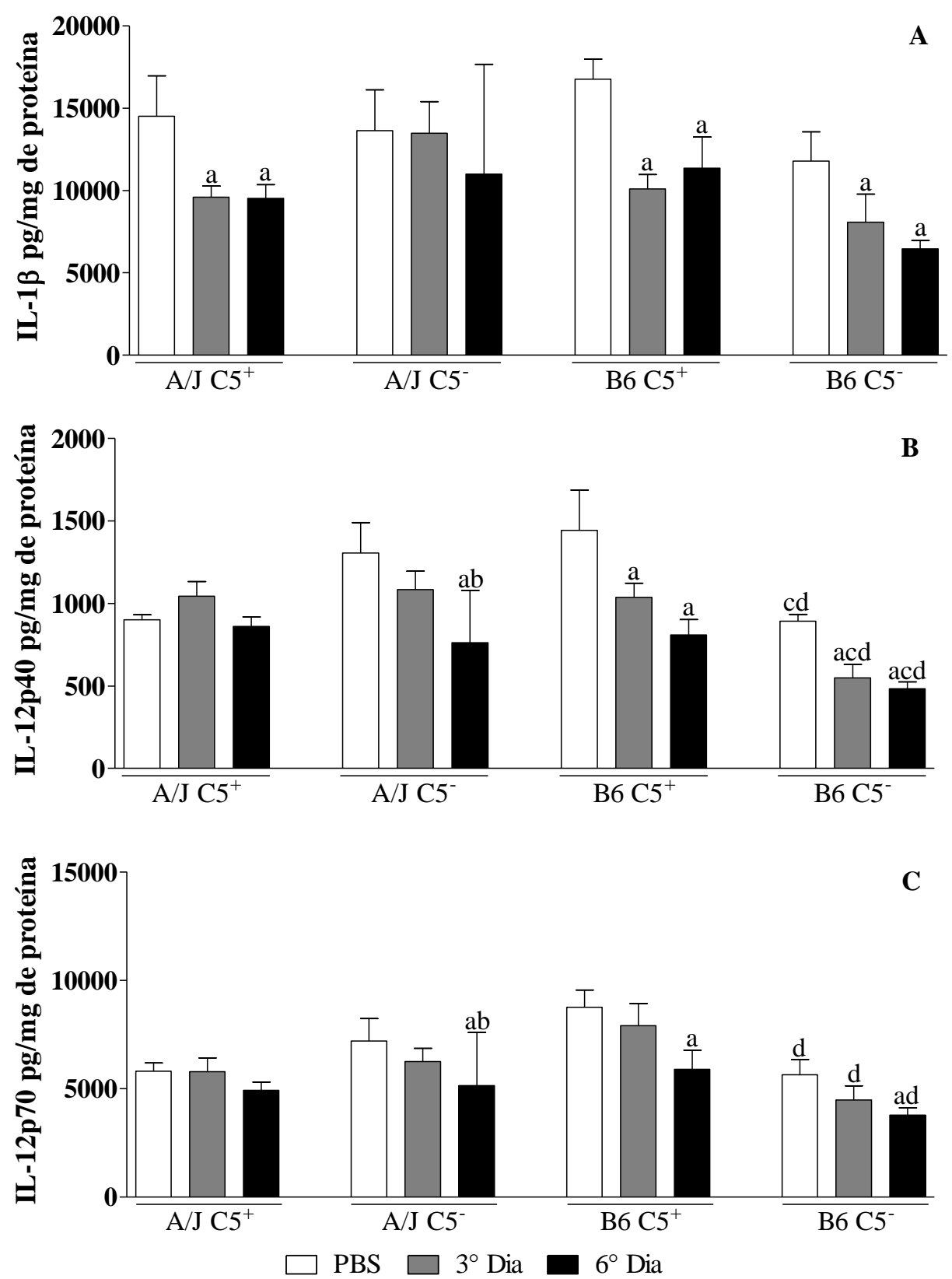

Variação das concentrações de citocinas no rim de camundongos infectados com $1,5 \times 10^{8}$ LPF. (A) IL-1 (B) IL-12p40. (C) IL-12p70. A/J C5 $5^{+}\left(\mathrm{PBS} n=5 ; 3^{\circ}\right.$ dia $n=12 ; 6^{\circ}$ dia $\left.n=9\right), A / J$ C5 $\left(P B S ~ n=4 ; 3^{\circ}\right.$ dia $n=10$; $6^{\circ}$ dia $\left.\mathrm{n}=9\right), \mathrm{B} 6 ~^{\mathrm{C}} 5^{+}\left(\mathrm{PBS} \mathrm{n}=5 ; 3^{\circ}\right.$ dia $\mathrm{n}=10 ; 6^{\circ}$ dia $\left.\mathrm{n}=10\right)$ e B6 C5 $\left(\mathrm{PBS} \mathrm{n}=5 ; 3^{\circ}\right.$ dia $\mathrm{n}=11 ; 6^{\circ}$ dia $\left.\mathrm{n}=10\right)$. Barras brancas correspondem ao grupo PBS, barras cinzas ao $3^{\circ}$ dia e barras pretas ao $6^{\circ}$ dia de infecção. a: diferente do PBS; b: diferente do terceiro dia; $\mathbf{c}$ : diferença entre linhagens, independente de C5; d: diferenças entre $\mathrm{C}^{+}$e $\mathrm{C}^{-}$no mesmo fundo genético. As diferenças correspondem à $p<0,05$.

Camundongos B6 $\mathrm{C}^{+}$possuem maiores concentrações de IL-6 e TNF que A/J C5 ${ }^{+}$ (Figura 27A e B), enquanto a linhagem B6 C5 ${ }^{-}$apresenta níveis reduzidos de IL-6, IL-10 e IL-12p40 em relação à A/J C5 (Figuras 27A-B e 28B, respectivamente), independentemente do tempo de infecção. Há uma tendência de redução na concentração de citocinas no rim dos 
camundongos infectados com leptospiras, sendo observado nos animais infectados menores níveis de IL-6, independente de C5 e do fundo genético (Figura 27B), de IL-1 $\beta$ em A/J C5 ${ }^{+}$e em camundongos B6 independente de C5 (Figura 28A), IL-12p40 em B6, independente de C5, e em A/J C5 ${ }^{-}$no $6^{\circ}$ dia de infecção (Figura 28B), e de IL-10 e IL-12p70 no $6^{\circ}$ dia de infecção em A/J C5', B6 C5+ e B6 C5 (Figuras 27C e 28C).

\subsubsection{Concentração de citocinas no pulmão durante infecção com $1,5 \times 10^{8} \mathrm{LPF}$}

A concentração de algumas citocinas no pulmão foi influenciada principalmente pelo fundo genético das linhagens utilizadas. Camundongos B6, independente de C5, apresentam menores concentrações de IL-6, IL-10 (Figura 29A e B), IL-1 $\beta$ e IL-12p40 (Figura 30A e B) no pulmão que camundongos $\mathrm{A} / \mathrm{J}$. Camundongos $\mathrm{B} 6 \mathrm{C}^{+}$também possuem menores concentrações de IL-12p70 que A/J C5 ${ }^{+}$(Figura 30C) quando inoculados com PBS e no $6^{\circ}$ dia de infecção.

Camundongos A/J, independente de C5, apresentam queda dos níveis de IL-12p40 no terceiro dia de infecção (Figura 30B), sendo observado esse mesmo padrão na concentração de IL-1 $\beta$ no terceiro dia em A/J C5- (Figura 30A).

Foi observado o aumento dos níveis de TNF (Figura 29A) e IL-12p70 (Figura 30C) no $3^{\circ}$ dia de infecção apenas na linhagem B6 $\mathrm{C}^{+}$, e queda da concentração de IL-1 $\beta$ (Figura 30A) $3^{\circ}$ dia e IL-12p40 (Figura 30B) no $6^{\circ}$ dia de infecção em B6 C5 .

A ausência de C5 ocasionou maiores níveis basais de TNF (Figura 29A) e IL-12p70 (Figura 30C) apenas no fundo genético B6, e de IL-10 em ambos os fundos genéticos quando inoculados com PBS. 
Figura 29 - Concentração de TNF, IL-6 e IL-10 no pulmão de camundongos infectados com $1,5 \times 10^{8} \mathrm{LPF}$
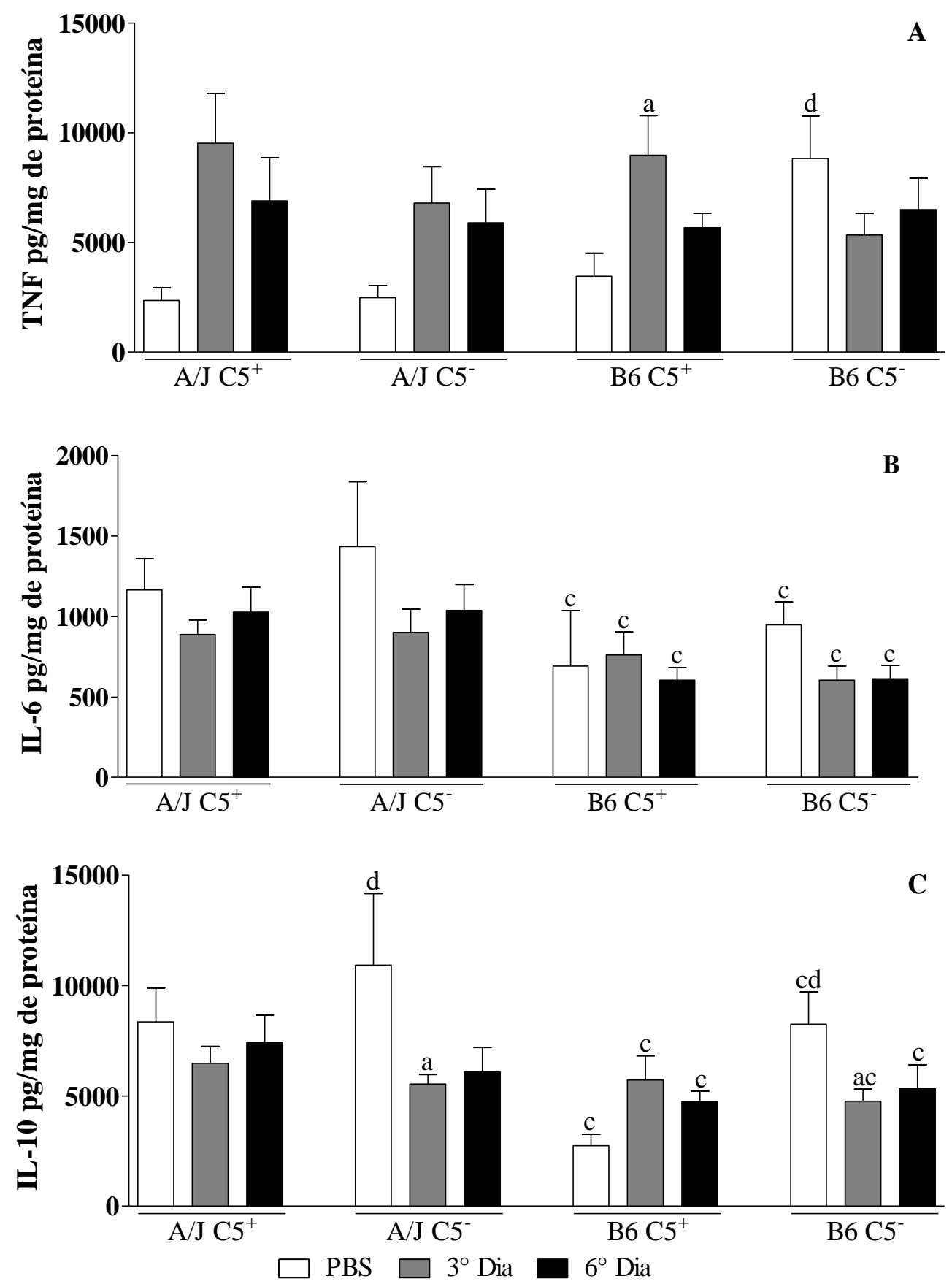

Variação das concentrações de citocinas pró e anti-inflamatórias no pulmão de camundongos infectados com $1,5 \times 10^{8}$ LPF. (A) TNF. (B) IL-6. (C) IL-10. A/J C5 $5^{+}$(PBS $n=5 ; 3^{\circ}$ dia $n=12 ; 6^{\circ}$ dia $n=9$ ), A/J C5 (PBS $\mathrm{n}=4 ; 3^{\circ}$ dia $\mathrm{n}=10 ; 6^{\circ}$ dia $\left.\mathrm{n}=9\right)$, B6 $\mathrm{C}^{+}\left(\mathrm{PBS} \mathrm{n}=5 ; 3^{\circ}\right.$ dia $\mathrm{n}=10 ; 6^{\circ}$ dia $\left.\mathrm{n}=10\right)$ e B6 C5 $\left(\mathrm{PBS} \mathrm{n}=5 ; 3^{\circ}\right.$ dia $\mathrm{n}=12 ; 6^{\circ}$ dia $\mathrm{n}=10$ ). Barras brancas correspondem ao grupo PBS, barras cinzas ao $3^{\circ}$ dia e barras pretas ao $6^{\circ}$ dia de infecção. a: diferente do PBS; c: diferença entre linhagens, independente de $\mathrm{C} 5$; d: diferenças entre $\mathrm{C}^{+} \mathrm{e}$ C5 ${ }^{-}$no mesmo fundo genético. As diferenças correspondem à $p<0,05$. 
Figura 30 - Concentração de IL-1 $\beta$, IL-12p40 e IL-12p70 no pulmão de camundongos infectados com $1,5 \times 10^{8} \mathrm{LPF}$
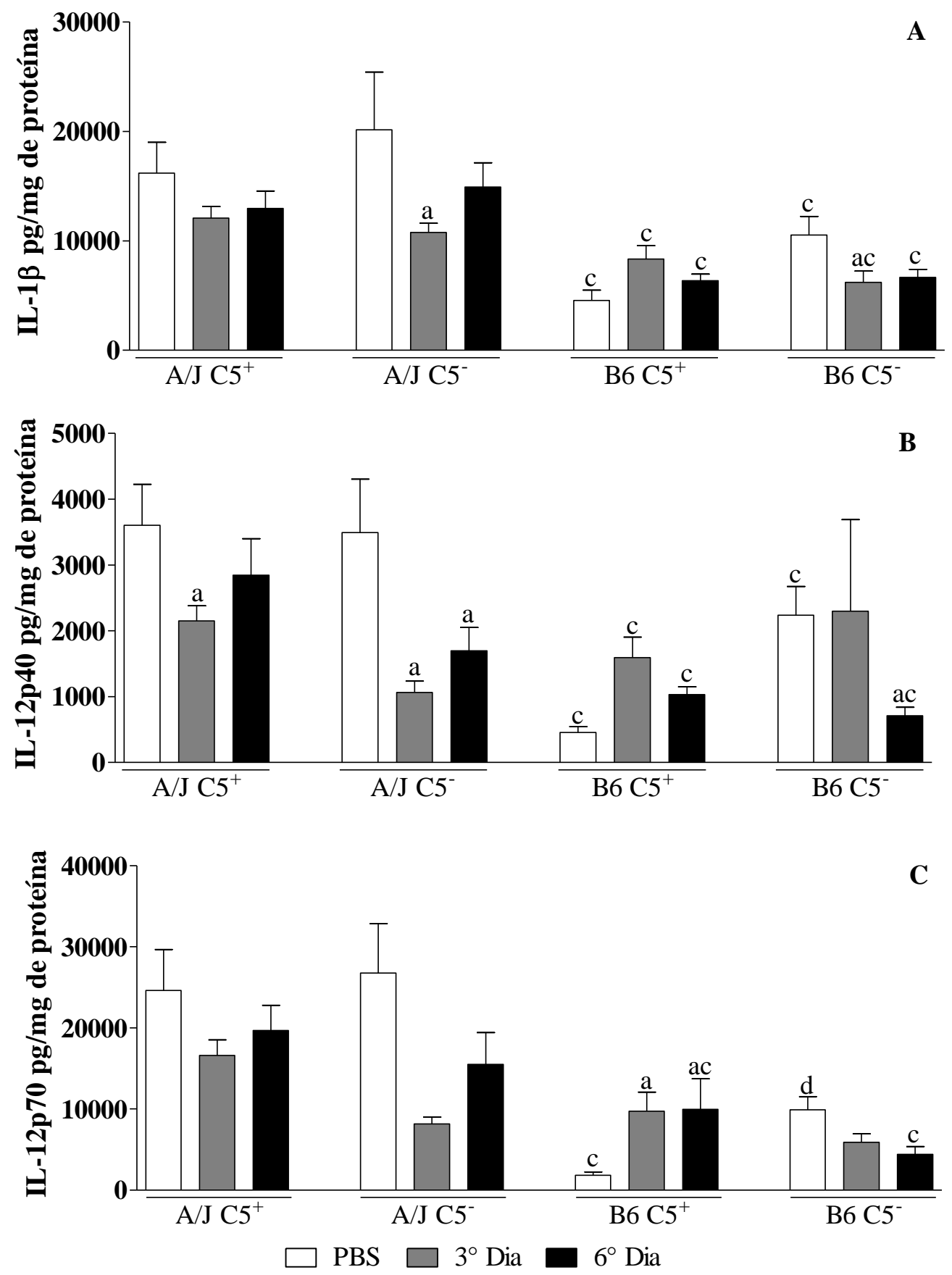

Variação das concentrações de citocinas no rim de camundongos infectados com $1,5 \times 10^{8}$ LPF. (A) IL-1 $\beta$. (B) IL-12p40. (C) IL-12p70. A/J C5 $5^{+}\left(\mathrm{PBS} n=5 ; 3^{\circ}\right.$ dia $\mathrm{n}=12 ; 6^{\circ}$ dia $\mathrm{n}=9$ ), A/J C5 $\left(\mathrm{PBS} \mathrm{n}=4 ; 3^{\circ}\right.$ dia $\mathrm{n}=10$;

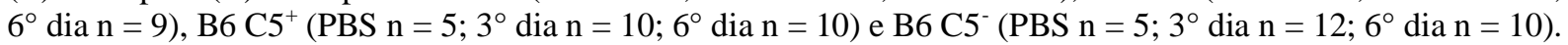
Barras brancas correspondem ao grupo PBS, barras cinzas ao $3^{\circ}$ dia e barras pretas ao $6^{\circ}$ dia de infecção. a: diferente do PBS; c: diferença entre linhagens, independente de $\mathrm{C} 5$; d: diferenças entre $\mathrm{C}^{+}$e $\mathrm{C}^{-}$no mesmo fundo genético. As diferenças correspondem à $p<0,05$. 


\subsubsection{Análise histopatológica de camundongos infectados com $1,5 \times 10^{8} \mathrm{LPF}$}

A análise dos órgãos dos camundongos infectados confirmou a presença de alterações histopatológicas no fígado, pulmão e baço de camundongos de todas as linhagens no terceiro e no sexto dia de infecção, enquanto o rim permaneceu inalterado em todos os animais durante o experimento.

Foram observados infiltrados leucocitários ao redor dos espaços porta e dentro dos sinusóides hepáticos e aumento do número de células de Küpffer nos sinusóides em todos os grupos infectados com LPF (Figuras 31 e 32). Também foram encontradas células mitóticas a partir do terceiro dia na linhagem $\mathrm{B} 6 \mathrm{C}^{+}$. No sexto dia houve redução do número e do tamanho dos infiltrados leucocitários em todas das linhagens e aparecimento de células

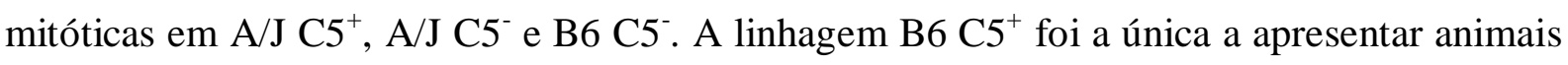
com áreas de necrose no fígado no terceiro dia de infecção (Figura 31B). O grau de lesão hepática foi semelhante entre as linhagens $\mathrm{A} / \mathrm{J} \mathrm{C}^{+}$e A/J C5 , apresentando poucas variações entre o terceiro e sexto dia de infecção. Houve diferenças entre A/J $\mathrm{C}^{+}$e $\mathrm{B} 6 \mathrm{C}^{+}$e entre B6 $\mathrm{C5}^{+}$e B6 $\mathrm{C5}^{-}$no terceiro dia de infecção, sendo sempre mais intensa na linhagem B6 C5 portanto, mostrando uma variação dependente de C5 e do fundo genético (Figura 33). 
Figura 31 - Lesões observadas no fígado de camundongos B6 infectados com 1,5 x 10 LPF

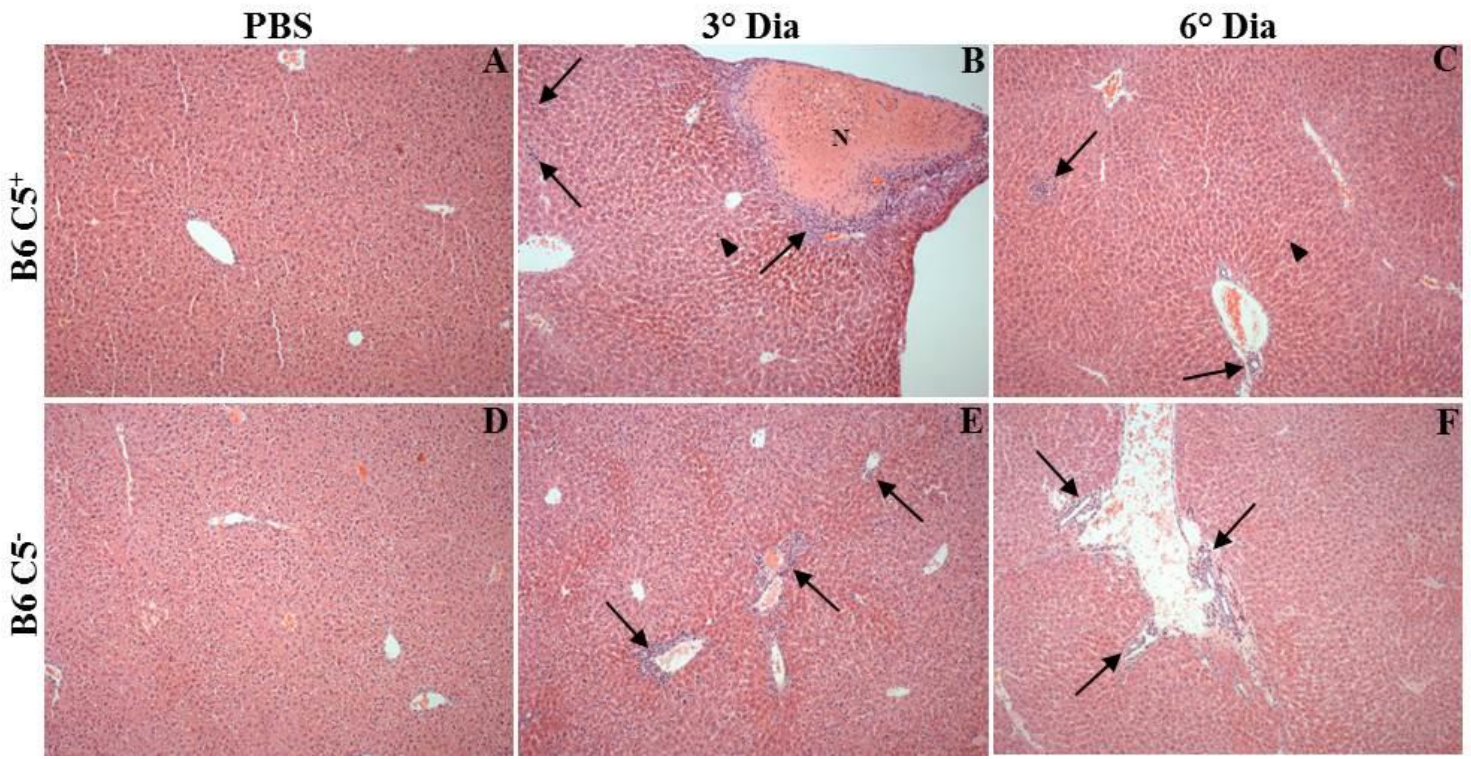

As imagens A, B e C correspondem, respectivamente, ao fígado de camundongos $\mathrm{B} 6 \mathrm{C}^{+}$inoculados com PBS ou infectados com $1,5 \times 10^{8}$ LPF e eutanasiados no terceiro ou no sexto dia de infecção. As imagens D, E e F correspondem, respectivamente, ao fígado de camundongos B6 $\mathrm{C}^{-}$inoculados com PBS ou infectados com $1,5 \times 10^{8}$ LPF e eutanasiados no terceiro ou no sexto dia de infecção. As setas indicam infiltrados leucocitários no espaço porta e nos sinusóides hepáticos. As cabeças de seta indicam células mitóticas. N: necrose. Coloração em HE. Aumento de 100x.

Figura 32 - Lesões observadas no fígado de camundongos A/J infectados com 1,5 x $10^{8}$ LPF

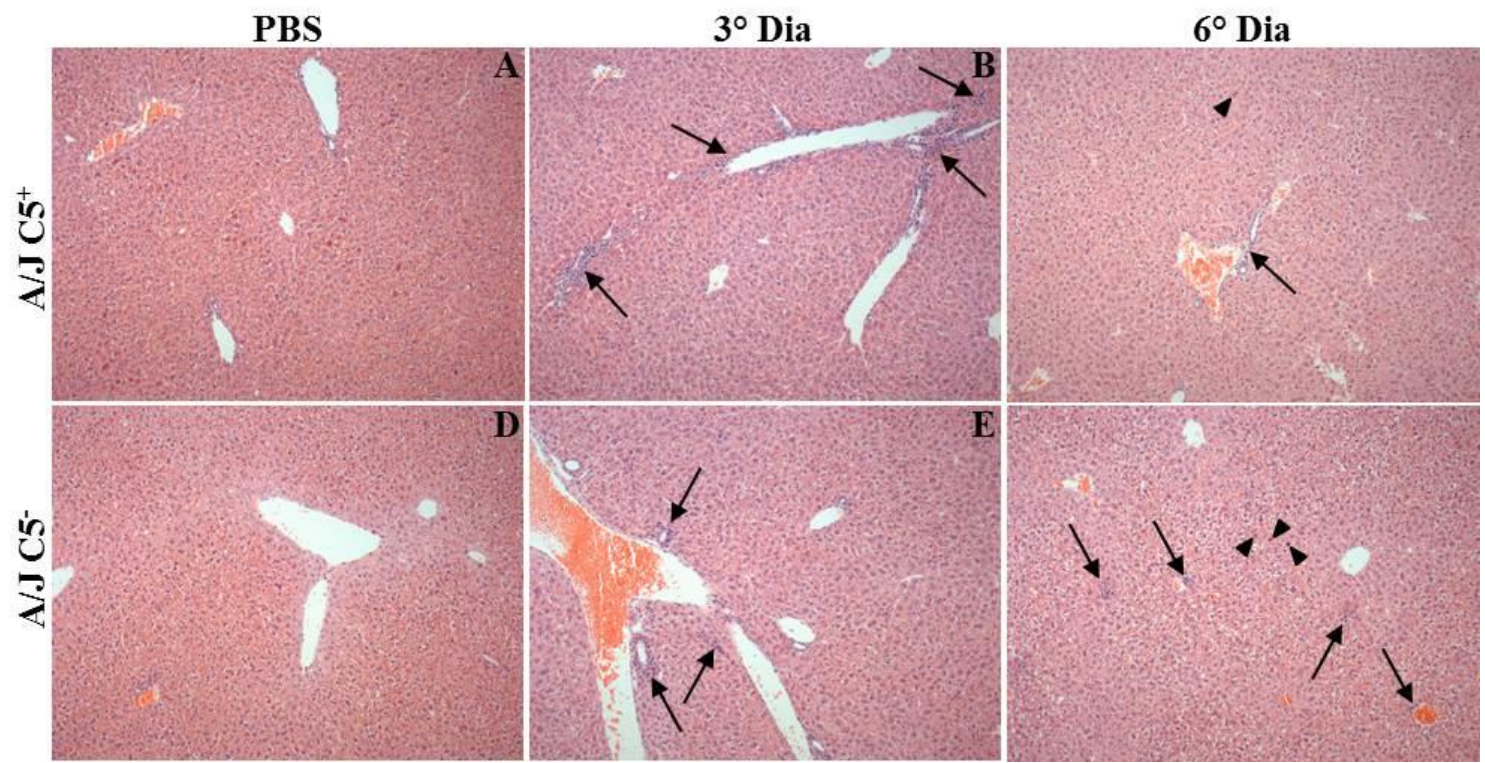

As imagens A, B e C correspondem, respectivamente, ao fígado de camundongos A/J $\mathrm{C}^{+}$inoculados com PBS ou infectados com $1,5 \times 10^{8} \mathrm{LPF}$ e eutanasiados no terceiro ou no sexto dia de infecção. As imagens D, E e F correspondem, respectivamente, ao fígado de camundongos A/J C5 inoculados com PBS ou infectados com 1,5 x $10^{8}$ LPF e eutanasiados no terceiro ou no sexto dia de infecção. As setas indicam infiltrados leucocitários no espaço porta e nos sinusóides hepáticos. As cabeças de seta indicam células mitóticas. Coloração em HE. Aumento de 100x. 
Figura 33 - Grau de lesão hepática dos camundongos infectados com 1,5 x $10^{8}$ LPF
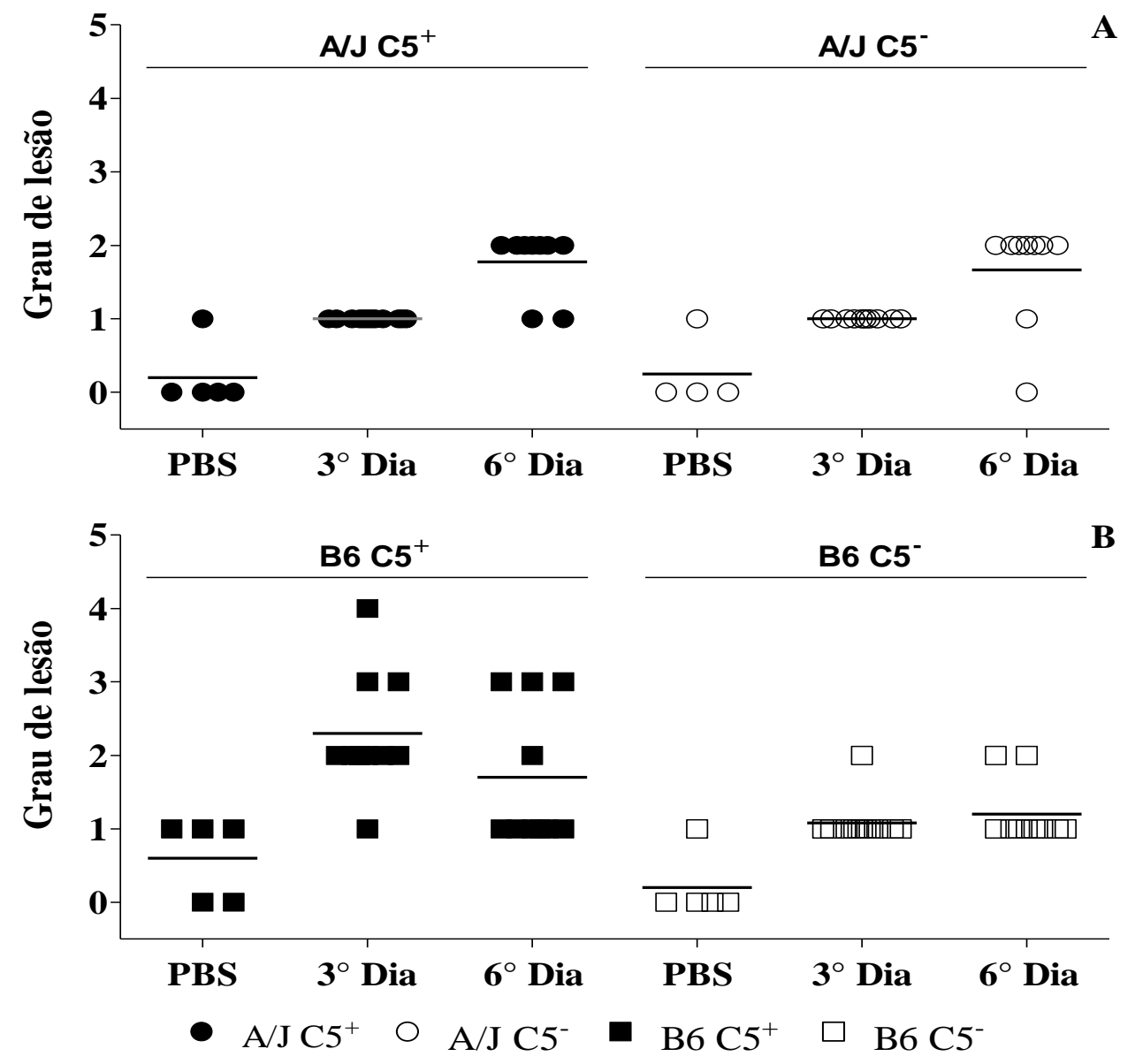

Intensidade da lesão hepática em camundongos A/J (A) e B6 (B) infectados com 1,5 x $10^{8}$ LPF. As linhas horizontais correspondem ao valor médio da lesão. A/J C5 $\left(\bullet-\mathrm{PBS} n=5 ; 3^{\circ}\right.$ dia $n=12 ; 6^{\circ}$ dia $\left.n=9\right), A / J$ C5 $\left(\mathrm{O}-\mathrm{PBS} \mathrm{n}=4 ; 3^{\circ}\right.$ dia $\mathrm{n}=10 ; 6^{\circ}$ dia $\left.\mathrm{n}=9\right)$, B6 $\mathrm{C}^{+}\left(\boldsymbol{\square}-\mathrm{PBS} \mathrm{n}=5 ; 3^{\circ}\right.$ dia $\mathrm{n}=10 ; 6^{\circ}$ dia $\left.n=10\right)$ e B6 C5 ( $\square-\operatorname{PBS} n=5 ; 3^{\circ}$ dia $n=12 ; 6^{\circ}$ dia $n=10$ ).

A análise do pulmão dos camundongos mostrou regiões que apresentaram aumento da espessura do septo alveolar (pneumonite intersticial, Figuras 34 e 35). Camundongos A/J C5 ${ }^{+}$ apresentaram focos isolados dessas lesões apenas no terceiro dia de infecção. As demais linhagens apresentaram focos isolados de pneumonite intersticial no terceiro dia e no sexto dia de infecção, havendo casos de pneumonite intersticial generalizada nas amostras de pulmão de alguns animais eutanasiados no sexto dia (Figuras 34 a 36). 
Figura 34 - Lesões pulmonares observadas nos camundongos B6 infectados com $1,5 \times 10^{8} \mathrm{LPF}$

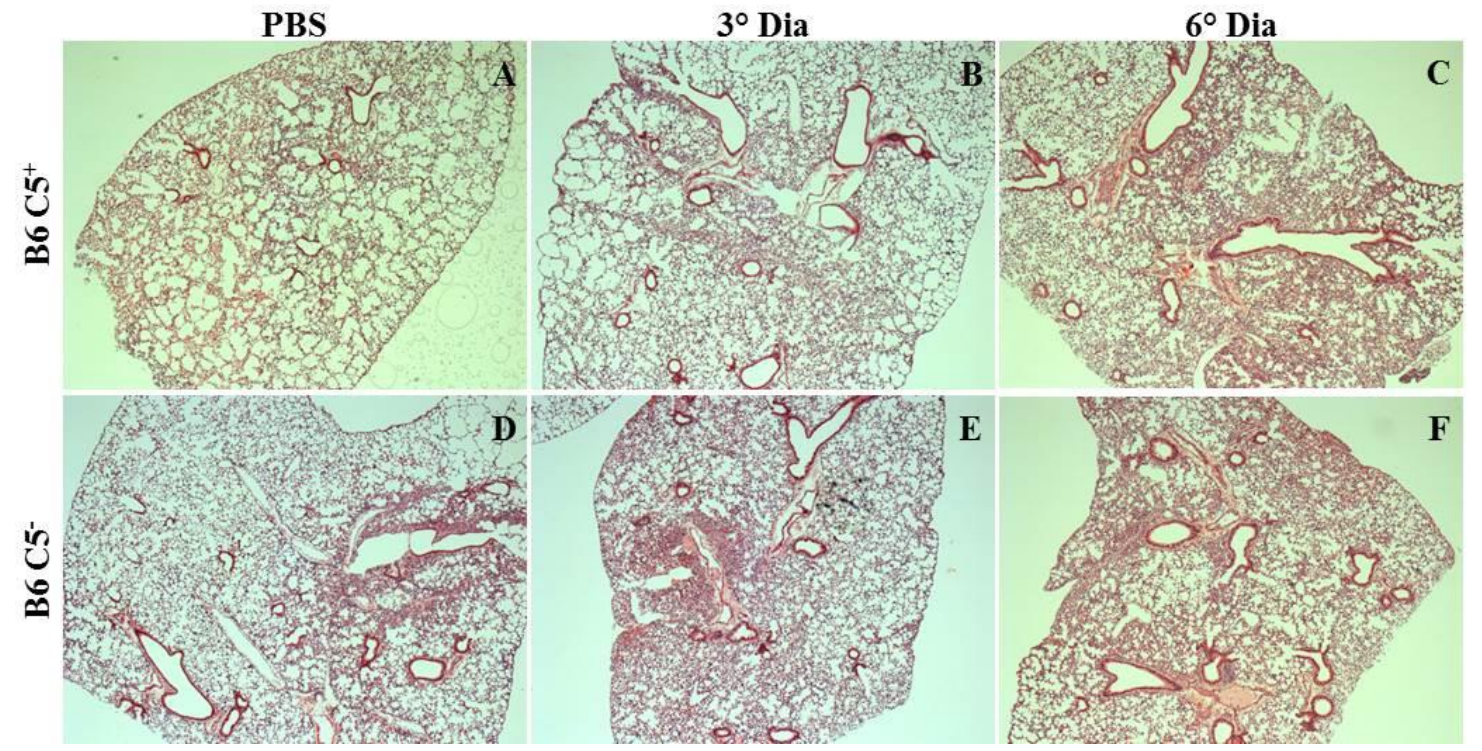

As imagens $\mathrm{A}, \mathrm{BC}$ e $\mathrm{C}$ correspondem, respectivamente, ao pulmão de camundongos $\mathrm{B} 6 \mathrm{C}^{+}$inoculados com $\mathrm{PBS}$ ou infectados com $1,5 \times 10^{8} \mathrm{LPF}$ e eutanasiados no terceiro ou no sexto dia de infecção. As imagens D, E e F correspondem, respectivamente, ao pulmão de camundongos B6 C5 inoculados com PBS ou infectados com $1,5 \times 10^{8} \mathrm{LPF}$ e eutanasiados no terceiro ou no sexto dia de infecção. Coloração em HE. Aumento de 40x.

Figura 35 - Lesões pulmonares observadas nos camundongos A/J infectados com $1,5 \times 10^{8} \mathrm{LPF}$
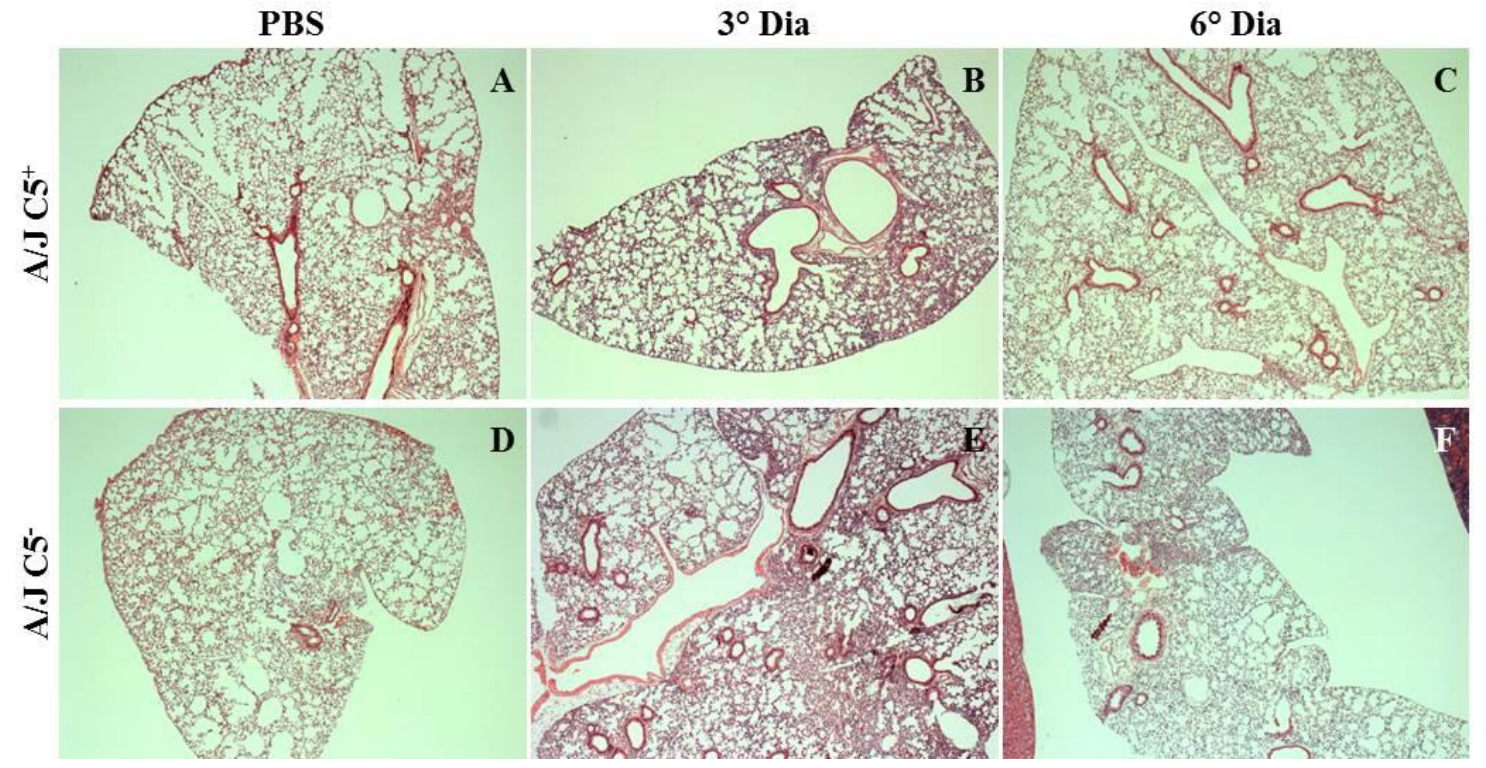

As imagens A, B e C correspondem, respectivamente, ao pulmão de camundongos $\mathrm{A} / \mathrm{J} \mathrm{C} 5^{+}$inoculados com PBS ou infectados com $1,5 \times 10^{8} \mathrm{LPF}$ e eutanasiados no terceiro ou no sexto dia de infecção. As imagens D, E e F correspondem, respectivamente, ao pulmão de camundongos $\mathrm{A} / \mathrm{J} \mathrm{C}^{-}$inoculados com PBS ou infectados com $1,5 \times 10^{8} \mathrm{LPF}$ e eutanasiados no terceiro ou no sexto dia de infecção. Coloração em HE. Aumento de 40x. 
Figura 36 - Grau de lesão pulmonar dos camundongos infectados com 1,5 x $10^{8} \mathrm{LPF}$
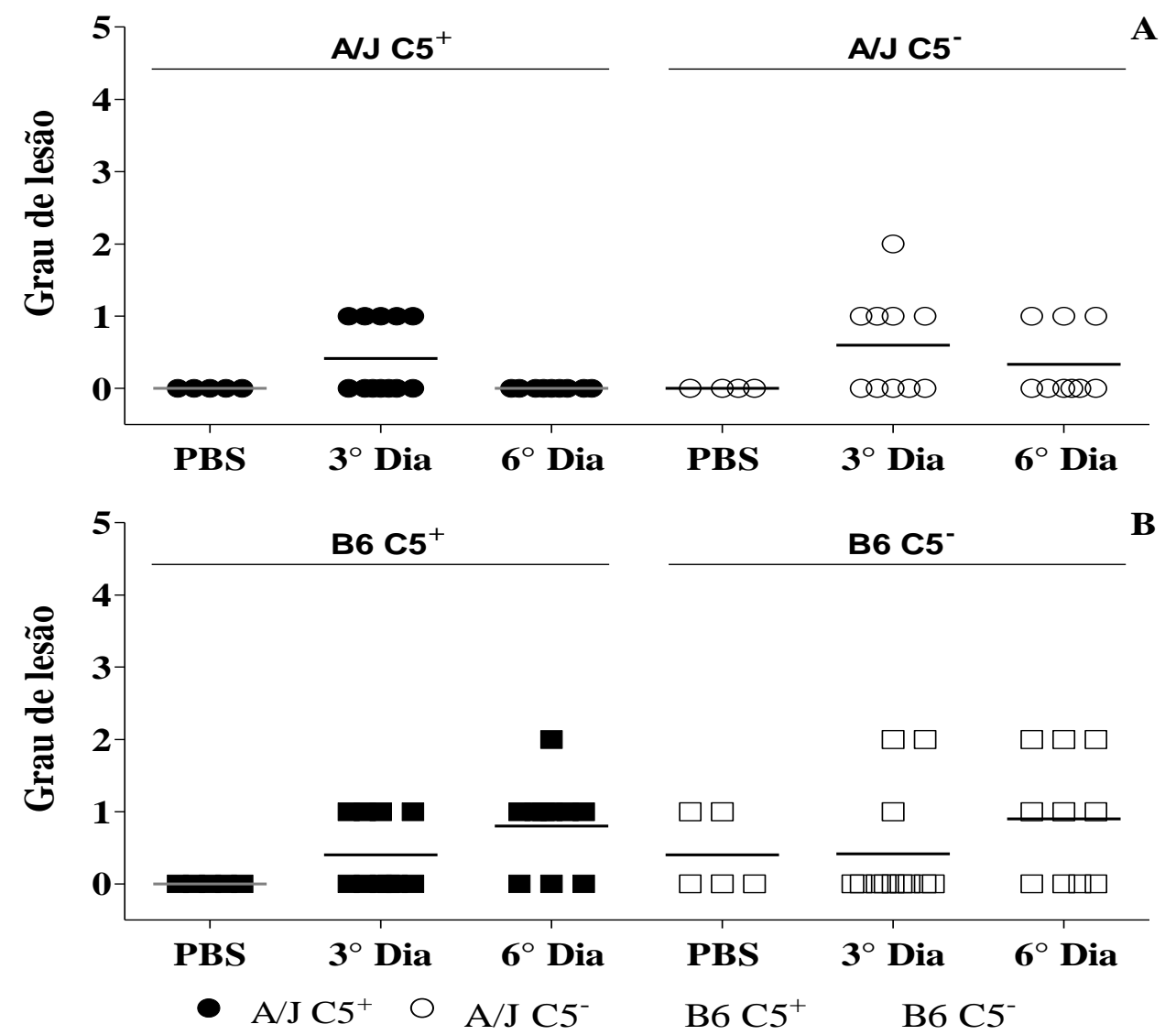

Intensidade da lesão pulmonar em camundongos A/J (A) e B6 (B) infectados com 1,5 x $10^{8}$ LPF. As linhas horizontais correspondem ao valor médio da lesão. A/J C5 $\left(\bullet-\mathrm{PBS} n=5 ; 3^{\circ}\right.$ dia $\mathrm{n}=12 ; 6^{\circ}$ dia $\left.n=9\right), \mathrm{A} / \mathrm{J} C 5^{-}$ ( O - PBS $n=4 ; 3^{\circ}$ dia $n=10 ; 6^{\circ}$ dia $\left.n=9\right)$, B6 C5 $5^{+}\left(\boldsymbol{D}-\mathrm{PBS} n=5 ; 3^{\circ}\right.$ dia $n=10 ; 6^{\circ}$ dia $\left.n=10\right)$ e B6 C5 $\left(\square-\operatorname{PBS} n=5 ; 3^{\circ}\right.$ dia $n=12 ; 6^{\circ}$ dia $n=10$ ).

Como observado na Fig. 20, todas as linhagens empregadas em nosso trabalho desenvolveram esplenomegalia mediante infecção por LPF. Ao analisarmos histopatologicamente o baço desses animais, observamos uma tendência de crescimento da polpa branca nos animais infectados, seguido pela expansão clonal dos linfócitos presentes nessa região (Figura 37). No terceiro dia há uma proporção maior de animais com maior atividade perifolicular, indicando proliferação majoritária dos linfócitos B, enquanto no sexto dia a maioria das linhagens apresenta também expansão de linfócitos $\mathrm{T}$ na região centrofolicular (Figuras 37 a 39). 
Figura 37 - Alterações observadas no baço de camundongos B6 infectados com $1,5 \times 10^{8} \mathrm{LPF}$

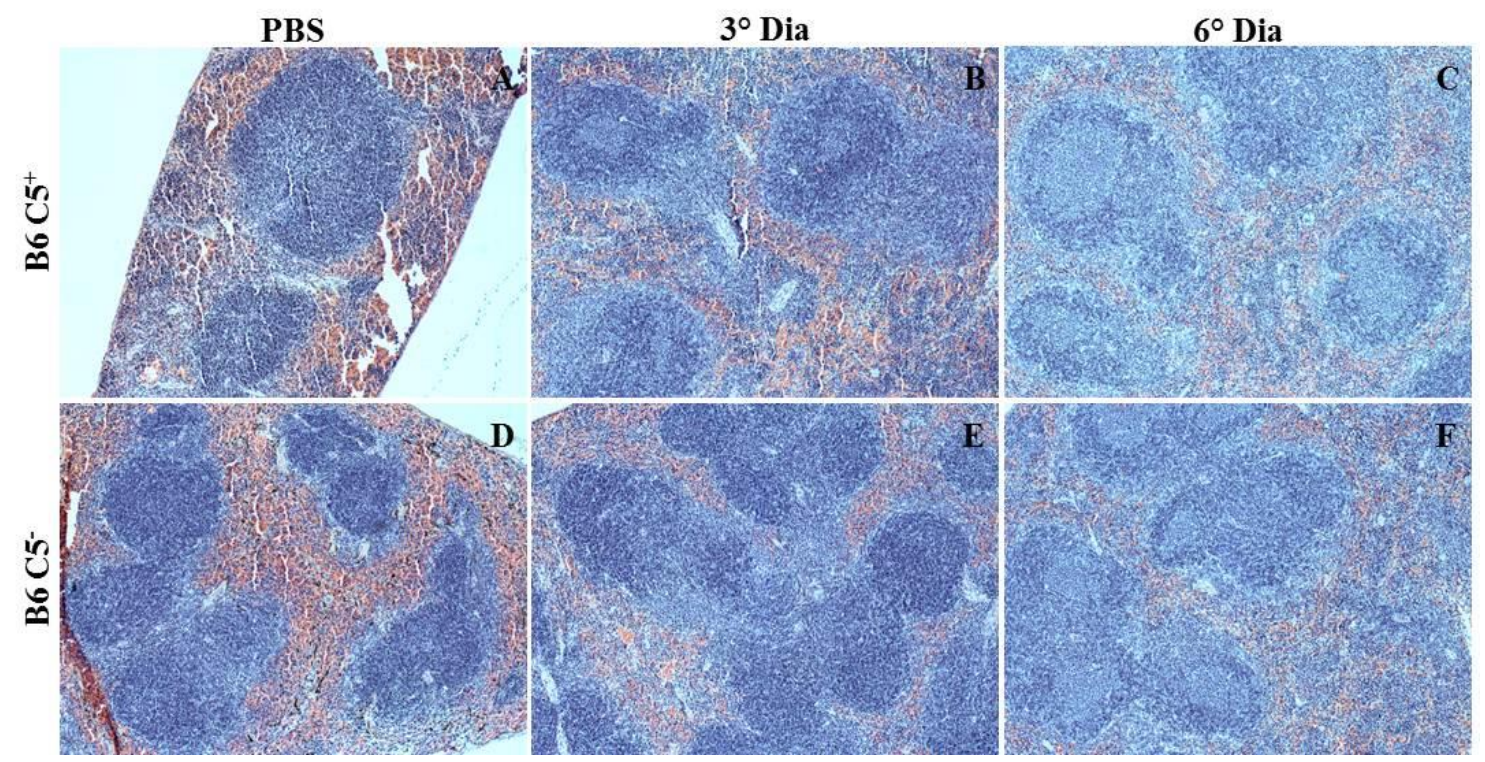

As imagens A, B e C correspondem, respectivamente, ao baço de camundongos B6 $\mathrm{C}^{+}$inoculados com PBS ou infectados com $1,5 \times 10^{8}$ LPF e eutanasiados no terceiro ou no sexto dia de infecção. As imagens D, E e F correspondem, respectivamente, ao baço de camundongos $\mathrm{B} 6 \mathrm{C5}^{-}$inoculados com PBS ou infectados com $1,5 \times 10^{8}$ LPF e eutanasiados no terceiro ou no sexto dia de infecção. Coloração em HE. Aumento de 100x.

Figura 38 - Alterações observadas no baço de camundongos A/J infectados com $1,5 \times 10^{8} \mathrm{LPF}$
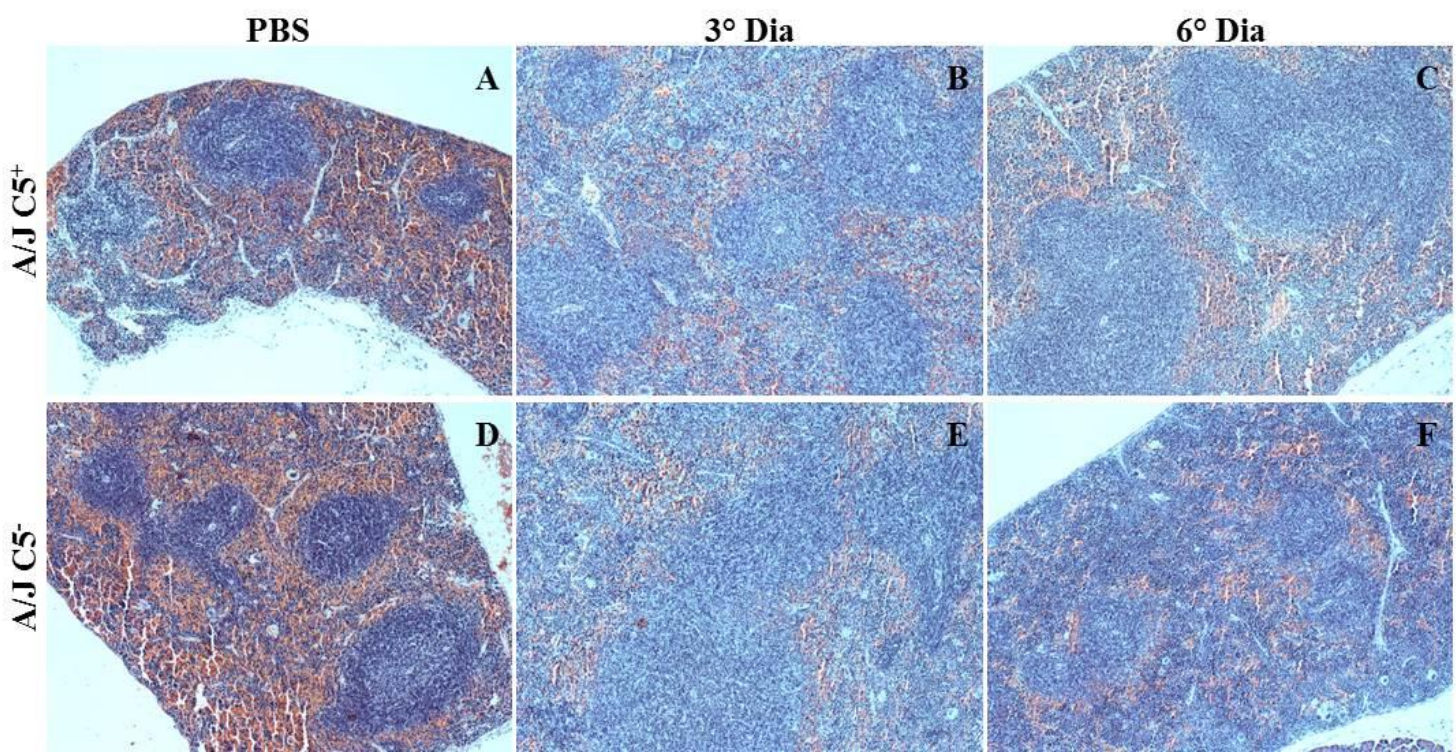

As imagens A,B e C correspondem, respectivamente, ao baço de camundongos A/J C5 ${ }^{+}$inoculados com PBS ou infectados com $1,5 \times 10^{8}$ LPF e eutanasiados no terceiro ou no sexto dia de infecção. As imagens D, E e F correspondem, respectivamente, ao baço de camundongos A/J C5 inoculados com PBS ou infectados com $1,5 \times 10^{8} \mathrm{LPF}$ e eutanasiados no terceiro ou no sexto dia de infecção. Coloração em HE. Aumento de 100x. 
Figura 39 - Grau de alteração esplênica nos camundongos infectados com 1,5 x $10^{8}$ LPF
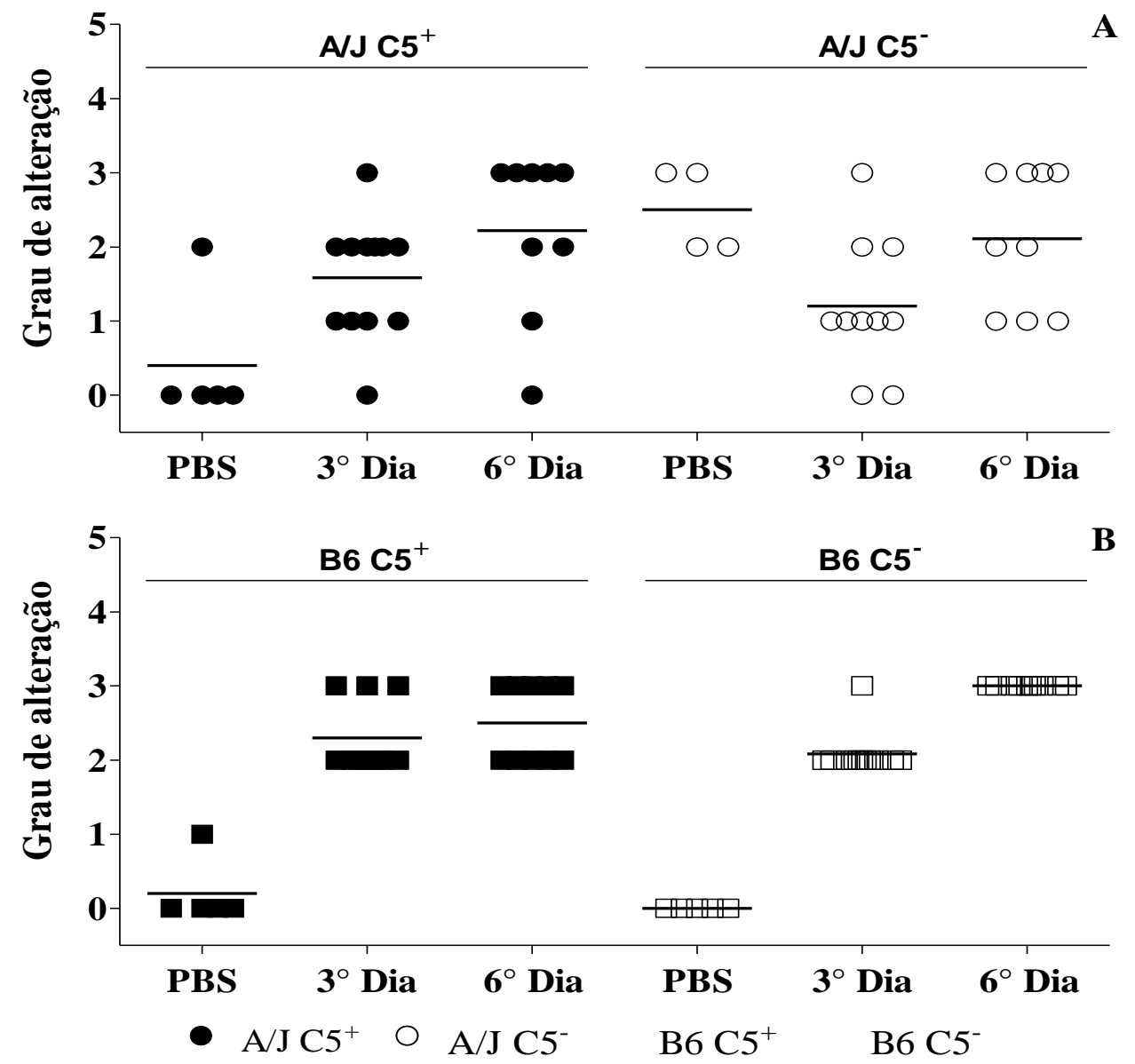

Intensidade da alteração no baço de camundongos A/J (A) e B6 (B) infectados com 1,5 x $10^{8}$ LPF. As linhas horizontais correspondem ao valor médio da alteração observada. A/J $\mathrm{C}^{+}\left(\bullet-\mathrm{PBS} \mathrm{n}=5 ; 3^{\circ}\right.$ dia $\mathrm{n}=12 ; 6^{\circ}$ dia $\mathrm{n}=9$ ), A/J C5 ( O - PBS $\mathrm{n}=4 ; 3^{\circ}$ dia $\mathrm{n}=10 ; 6^{\circ}$ dia $\left.\mathrm{n}=9\right)$, B6 C5 $5^{+}\left(\boldsymbol{\nabla}-\mathrm{PBS} \mathrm{n}=5 ; 3^{\circ}\right.$ dia $\mathrm{n}=10 ; 6^{\circ}$ dia $\left.\mathrm{n}=10\right)$ e B6 C5 $\left(\square-\operatorname{PBS} n=5 ; 3^{\circ}\right.$ dia $n=12 ; 6^{\circ}$ dia $\left.n=10\right)$. 0 indica a condição basal do baço. 1 indica o crescimento da polpa branca. 2 indica expansão apenas da ragião centrofolicular ou apenas da região perifolicular. 3 indica a expansão concomitante das regiões centrofolicular e perifolicular.

Em oposição ao que era esperado, não encontramos alterações renais que pudessem ter sido causadas pela infecção, permanecendo este órgão semelhante entre os animais infectados e os controles (Figuras 40 e $\mathbf{4 1}$ ). 
Figura 40 - Imagens do rim de camundongos B6 infectados com 1,5 x $10^{8} \mathrm{LPF}$
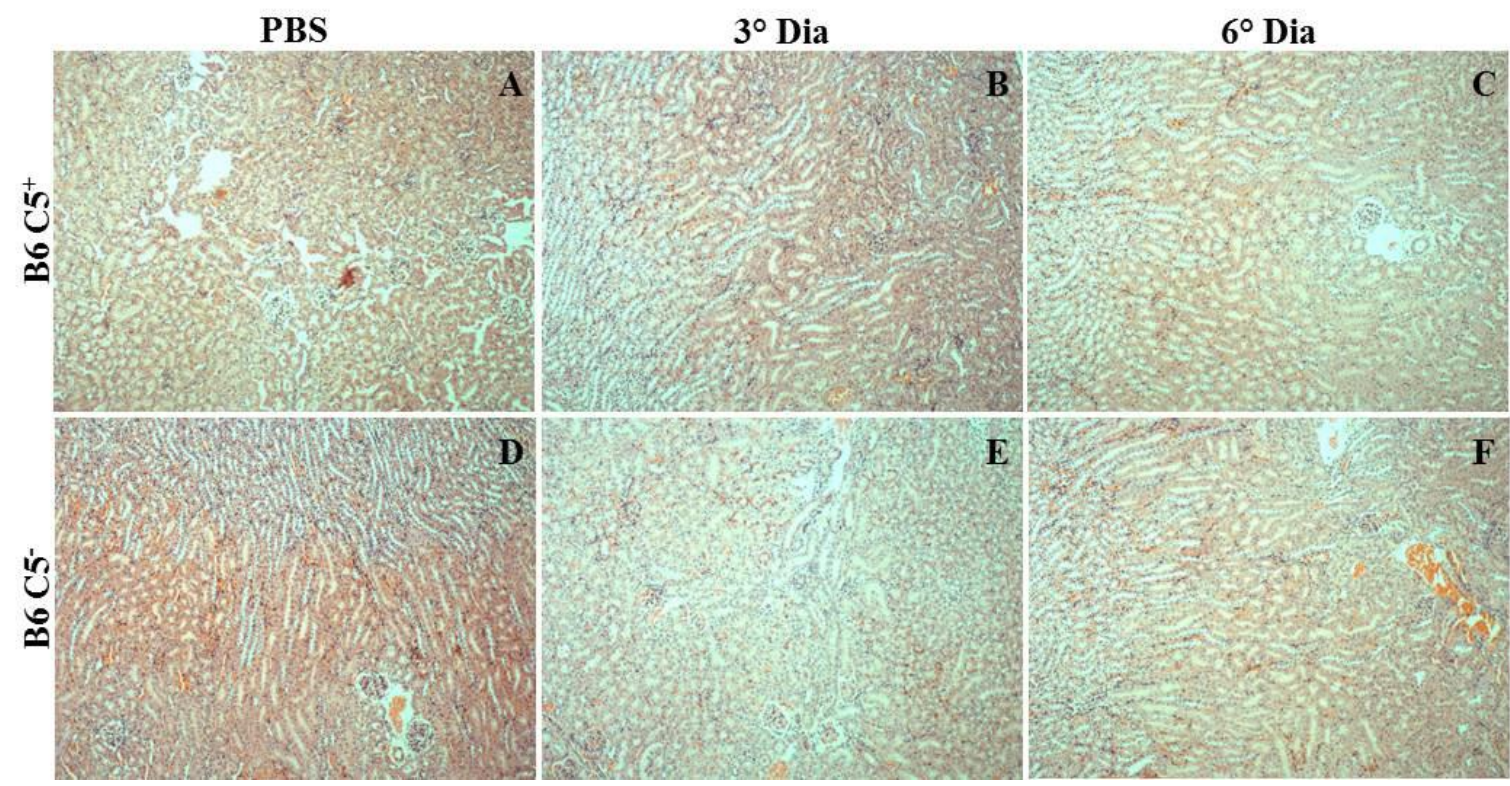

As imagens $\mathrm{A}, \mathrm{B}$ e $\mathrm{C}$ correspondem, respectivamente, ao rim de camundongos $\mathrm{B} 6 \mathrm{C}^{+}$inoculados com $\mathrm{PBS}$ ou infectados com $1,5 \times 10^{8}$ LPF e eutanasiados no terceiro ou no sexto dia de infecção. As imagens D, E e F correspondem, respectivamente, ao rim de camundongos B6 $\mathrm{C}^{-}$inoculados com PBS ou infectados com $1,5 \times 10^{8} \mathrm{LPF}$ e eutanasiados no terceiro ou no sexto dia de infecção. Coloração em HE. Aumento de 100x.

Figura 41 - Imagens do rim de camundongos A/J infectados com 1,5 x $10^{8}$ LPF

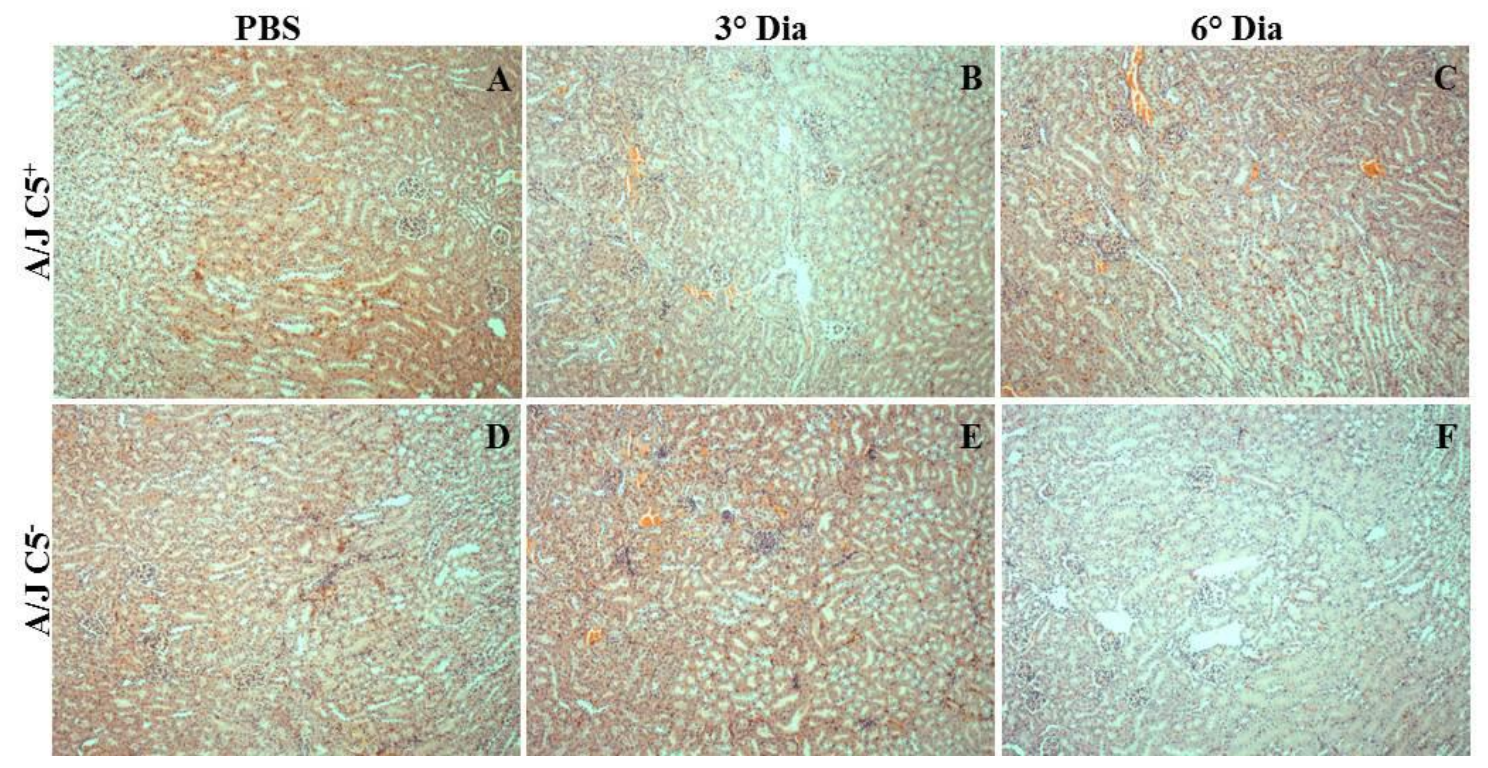

As imagens $\mathrm{A}, \mathrm{B}$ e $\mathrm{C}$ correspondem, respectivamente, ao rim de camundongos $\mathrm{A} / \mathrm{J} \mathrm{C}^{+}$inoculados com $\mathrm{PBS}$ ou infectados com $1,5 \times 10^{8}$ LPF e eutanasiados no terceiro ou no sexto dia de infecção. As imagens D, E e F correspondem, respectivamente, ao rim de camundongos $\mathrm{A} / \mathrm{J} \mathrm{C}^{-}$inoculados com PBS ou infectados com $1,5 \times 10^{8} \mathrm{LPF}$ e eutanasiados no terceiro ou no sexto dia de infecção. Coloração em HE. Aumento de 100x. 
4.3.9 Detecção de leptospiras por imuno-histoquímica em camundongos infectados com $1,5 \times 10^{8} \mathrm{LPF}$

A reação por imuno-histoquímica mostrou que os antígenos da LPF são detectados majoritariamente no fígado e no baço dos camundongos, havendo pouca detecção de leptospira no pulmão e no rim do controle positivo (Figura 42).

Figura 42 - Detecção de LPF por imuno-histoquímica em diferentes órgãos de um camundongo A/J C5 ${ }^{-}$infectado com $1,5 \times 10^{8} \mathrm{LPF}$

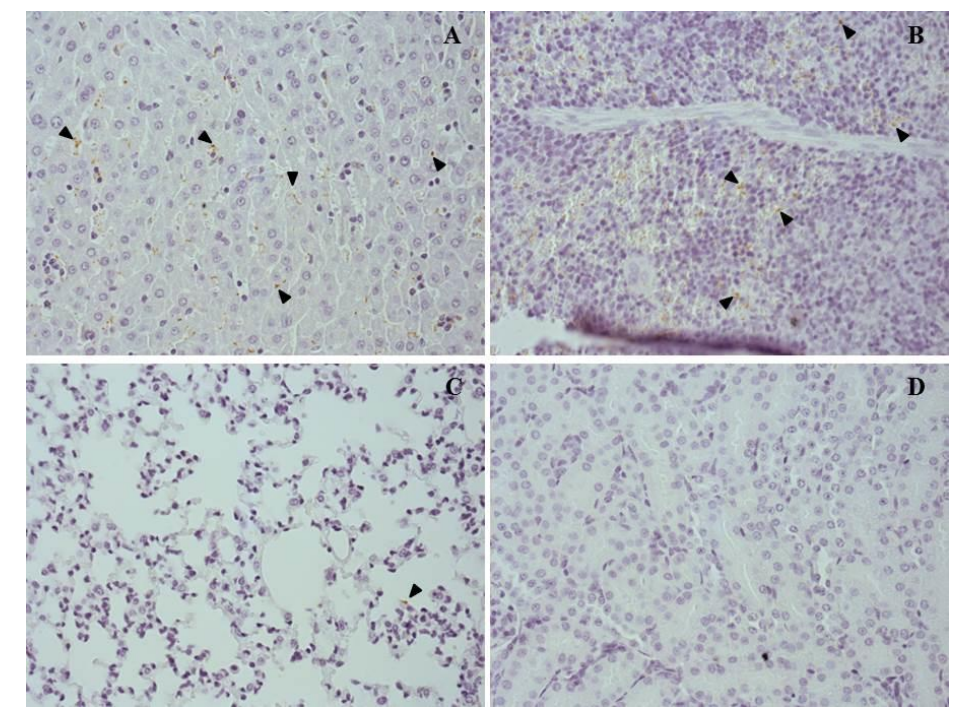

Marcação de LPF por IH (ponta da seta) em camundongo A/J C5 infectado com 1,5 x $10^{8}$ LPF que foi utilizado como controle positivo da reação. (A) Fígado. (B) Baço. (C) Pulmão. (D) Rim. As cabeças de seta indicam onde há marcação de LPF. Contra-coloração em hematoxilina. Aumento de 400x.

Foram encontrados antígenos da LPF em todos os animais infectados, principalmente no fígado (Figura 43 e 44) e no baço (Figura 45 e 46). Devido à variação da quantidade de LPF detectada entre os animais, não é possível encontrar diferenças significativas entre as linhagens, independentemente de haver ou não C5 no organismo, e entre o terceiro e o sexto dia de infecção.

A intensidade da marcação de LPF no fígado e no baço sempre foi proporcional nos animais, sendo que a detecção reduzida de leptospiras em um desses órgãos ocorria concomitante à baixa marcação de LPF no outro órgão, ocorrendo o mesmo nos casos de marcação intensa. Por fim, foi observado que os camundongos que desenvolveram maior atividade Th1 no baço, com proliferação dos linfócitos centro-foliculares, tenderam a eliminar mais rapidamente a LPF do organismo, sendo detectados poucos antígenos no fígado e no baço. 
Figura 43 - Detecção de LPF por imuno-histoquímica no fígado de camundongos B6 infectados com $1,5 \times 10^{8} \mathrm{LPF}$

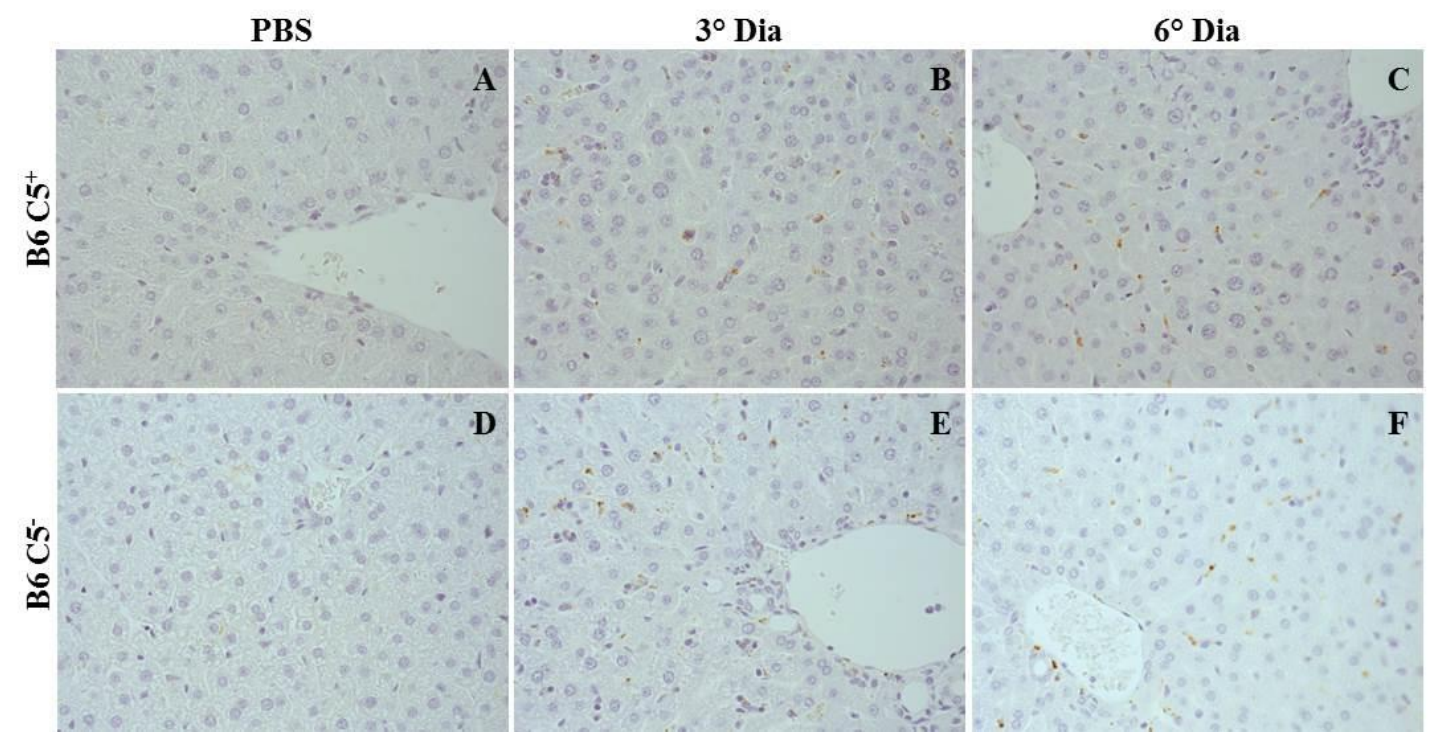

As imagens A, B e C correspondem, respectivamente, ao fígado de camundongos $\mathrm{B} 6 \mathrm{C}^{+}$inoculados com $\mathrm{PBS}$ ou infectados com $1,5 \times 10^{8}$ LPF e eutanasiados no terceiro ou no sexto dia de infecção. As imagens D, E e F correspondem, respectivamente, ao fígado de camundongos B6 $\mathrm{C}^{-}$inoculados com PBS ou infectados com $1,5 \times 10^{8} \mathrm{LPF}$ e eutanasiados no terceiro ou no sexto dia de infecção. Aumento de 400x.

Figura 44 - Detecção de LPF por imuno-histoquímica no fígado de camundongos A/J infectados com $1,5 \times 10^{8} \mathrm{LPF}$

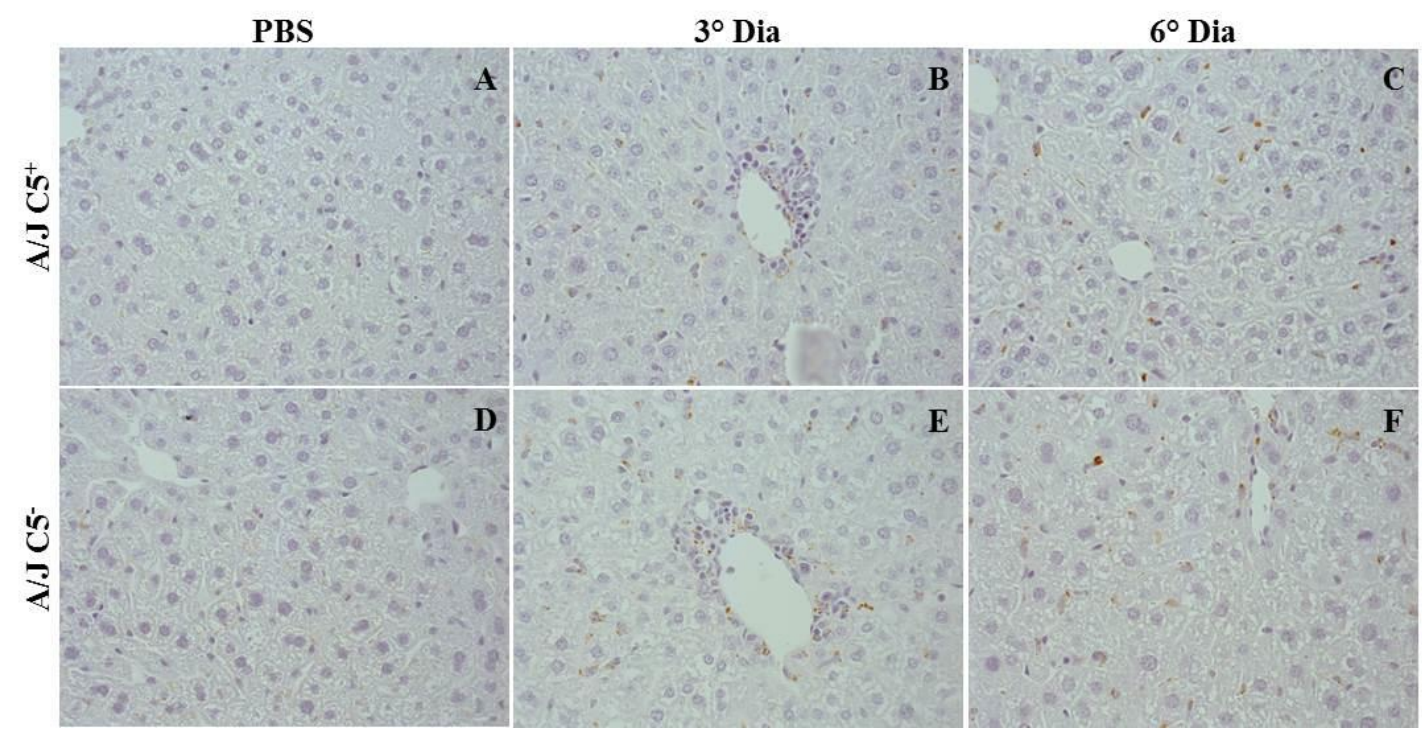

As imagens $\mathrm{A}, \mathrm{B}$ e $\mathrm{C}$ correspondem, respectivamente, ao fígado de camundongos $\mathrm{A} / \mathrm{J} \mathrm{C}^{+}$inoculados com $\mathrm{PBS}$ ou infectados com $1,5 \times 10^{8}$ LPF e eutanasiados no terceiro ou no sexto dia de infecção. As imagens D, E e F correspondem, respectivamente, ao fígado de camundongos A/J C5 inoculados com PBS ou infectados com $1,5 \times 10^{8} \mathrm{LPF}$ e eutanasiados no terceiro ou no sexto dia de infecção. Aumento de 400x. 
Figura 45 - Detecção de LPF por imuno-histoquímica no baço de camundongos B6 infectados com $1,5 \times 10^{8} \mathrm{LPF}$

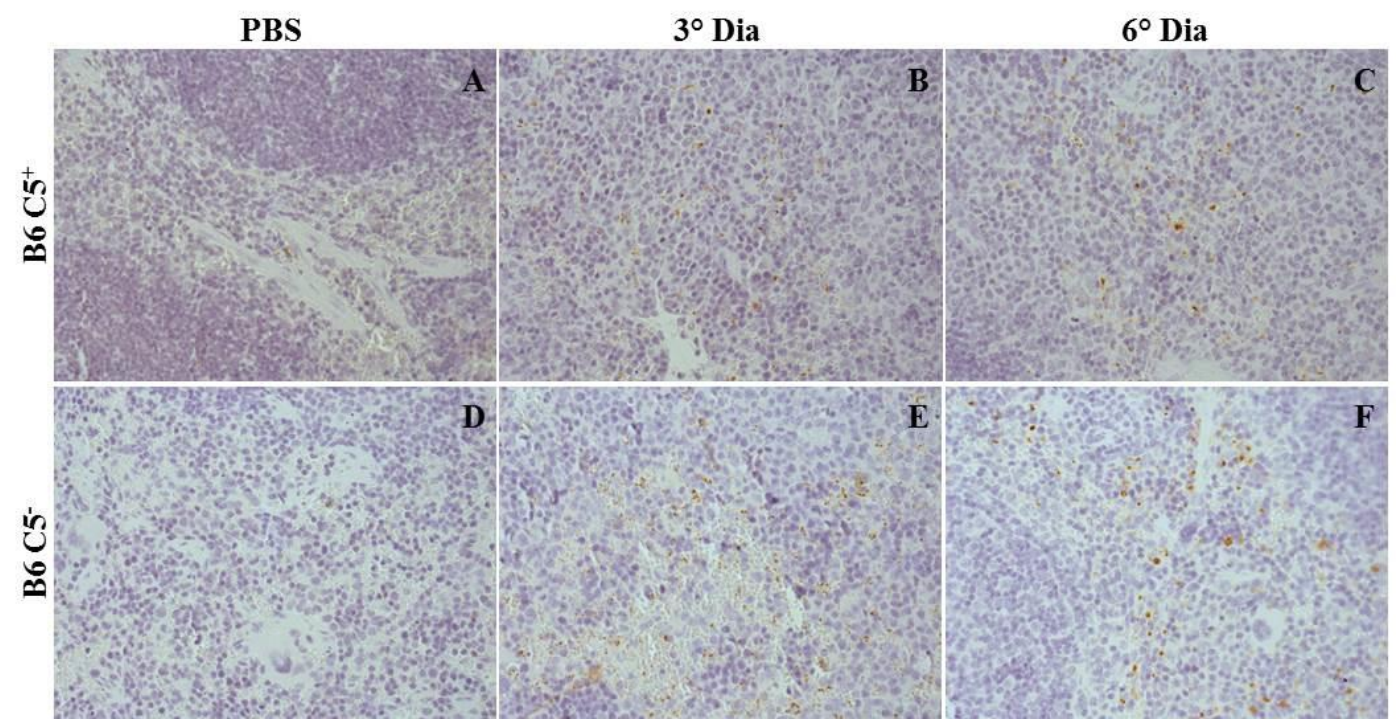

As imagens A, B e C correspondem, respectivamente, ao baço de camundongos $\mathrm{B} 6 \mathrm{C}^{+}$inoculados com PBS ou infectados com 1,5 x $10^{8}$ LPF e eutanasiados no terceiro ou no sexto dia de infecção. As imagens D, E e F correspondem, respectivamente, ao baço de camundongos B6 $\mathrm{C}^{-}$inoculados com PBS ou infectados com $1,5 \times 10^{8} \mathrm{LPF}$ e eutanasiados no terceiro ou no sexto dia de infecção. Aumento de 400x.

Figura 46 - Detecção de LPF por imuno-histoquímica no baço de camundongos A/J infectados com $1,5 \times 10^{8} \mathrm{LPF}$

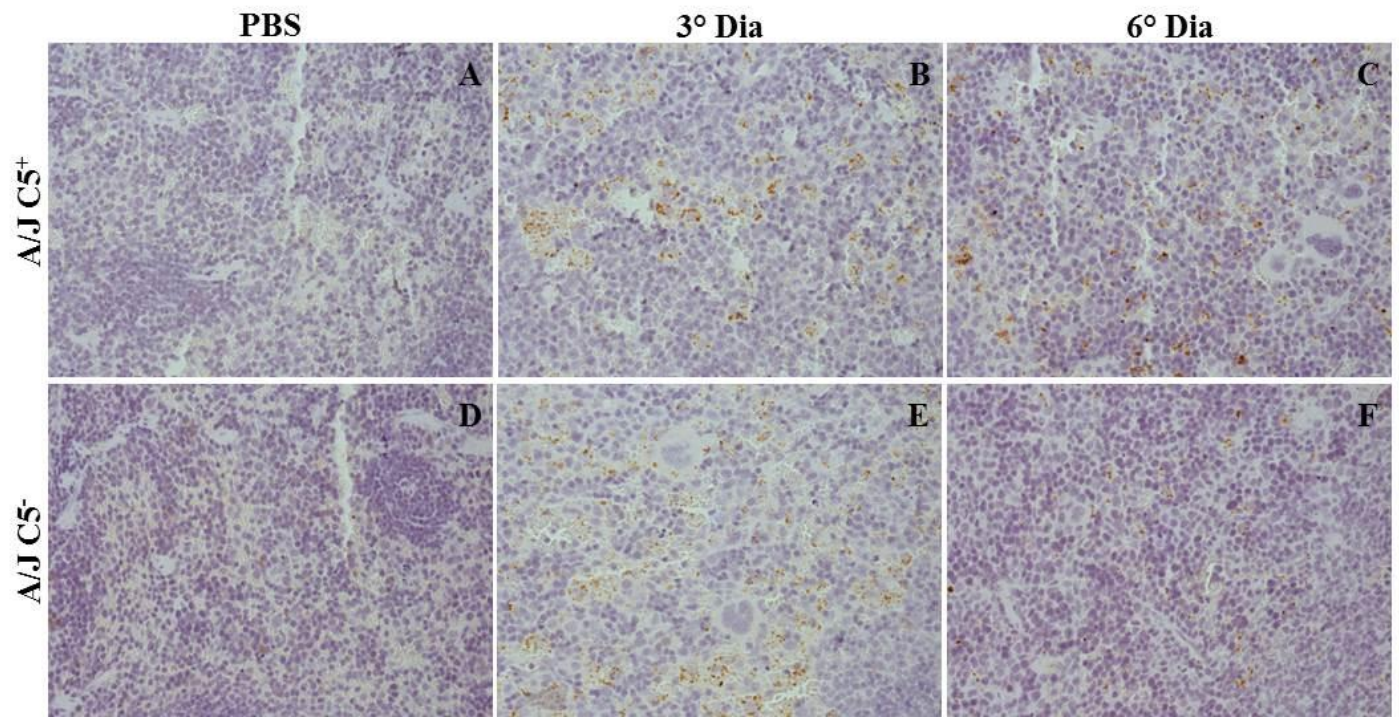

As imagens A, B e C correspondem, respectivamente, ao baço de camundongos $\mathrm{A} / \mathrm{J} \mathrm{C} 5^{+}$inoculados com PBS ou infectados com $1,5 \times 10^{8}$ LPF e eutanasiados no terceiro ou no sexto dia de infecção. As imagens D, E e F correspondem, respectivamente, ao baço de camundongos A/J $\mathrm{C}^{-}$inoculados com PBS ou infectados com $1,5 \times 10^{8} \mathrm{LPF}$ e eutanasiados no terceiro ou no sexto dia de infecção. Aumento de 400x.

Apesar das lesões pulmonares serem mais frequentes nos camundongos infectados, houve pouca detecção de LPF no pulmão dos camundongos (Figura 47 e 48), assim como 
não houve marcação significativa das leptospiras no rim (Figura 49 e 50) dos animais infectados, independentemente da linhagem.

Figura 47 - Detecção de LPF por imuno-histoquímica no pulmão de camundongos B6 infectados com $1,5 \times 10^{8} \mathrm{LPF}$

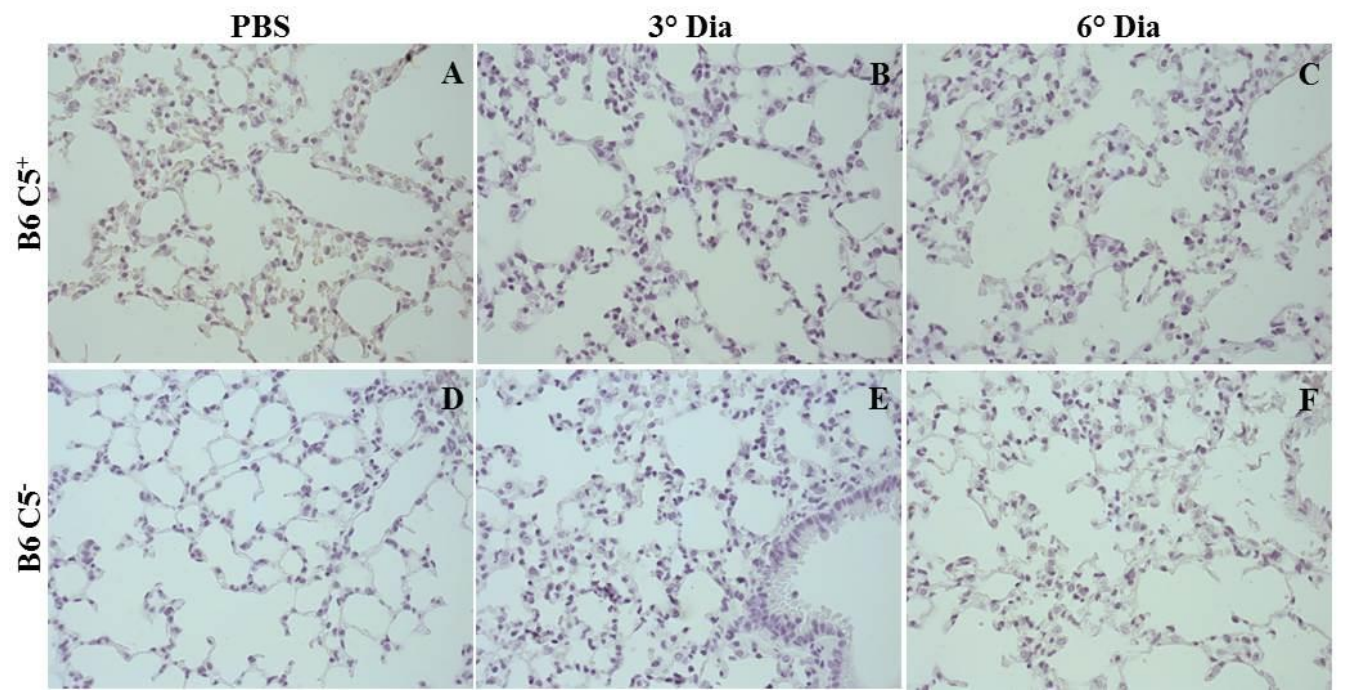

As imagens A, B e C correspondem, respectivamente, ao pulmão de camundongos $\mathrm{B} 6 \mathrm{C}^{+}$inoculados com PBS ou infectados com $1,5 \times 10^{8} \mathrm{LPF}$ e eutanasiados no terceiro ou no sexto dia de infecção. As imagens D, E e F correspondem, respectivamente, ao pulmão de camundongos B6 $\mathrm{C} 5^{-}$inoculados com PBS ou infectados com $1,5 \times 10^{8} \mathrm{LPF}$ e eutanasiados no terceiro ou no sexto dia de infecção. Aumento de 400x.

Figura 48 - Detecção de LPF por imuno-histoquímica no pulmão de camundongos A/J infectados com $1,5 \times 10^{8} \mathrm{LPF}$

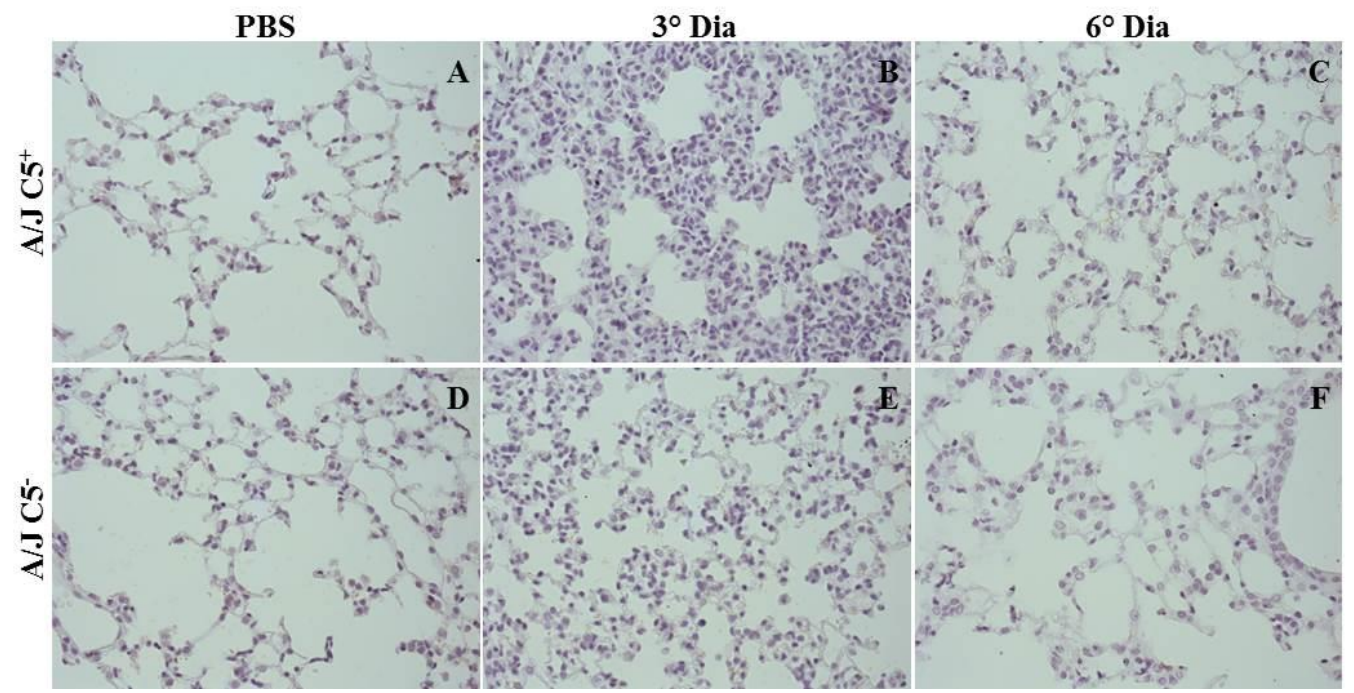

As imagens $\mathrm{A}, \mathrm{B}$ e $\mathrm{C}$ correspondem, respectivamente, ao pulmão de camundongos $\mathrm{A} / \mathrm{J} \mathrm{C}^{+}$inoculados com $\mathrm{PBS}$ ou infectados com $1,5 \times 10^{8} \mathrm{LPF}$ e eutanasiados no terceiro ou no sexto dia de infecção. As imagens D, E e F correspondem, respectivamente, ao pulmão de camundongos A/J C5 inoculados com PBS ou infectados com $1,5 \times 10^{8} \mathrm{LPF}$ e eutanasiados no terceiro ou no sexto dia de infecção. Aumento de 400x. 
Figura 49 - Detecção de LPF por imuno-histoquímica no rim de camundongos B6 infectados com $1,5 \times 10^{8} \mathrm{LPF}$

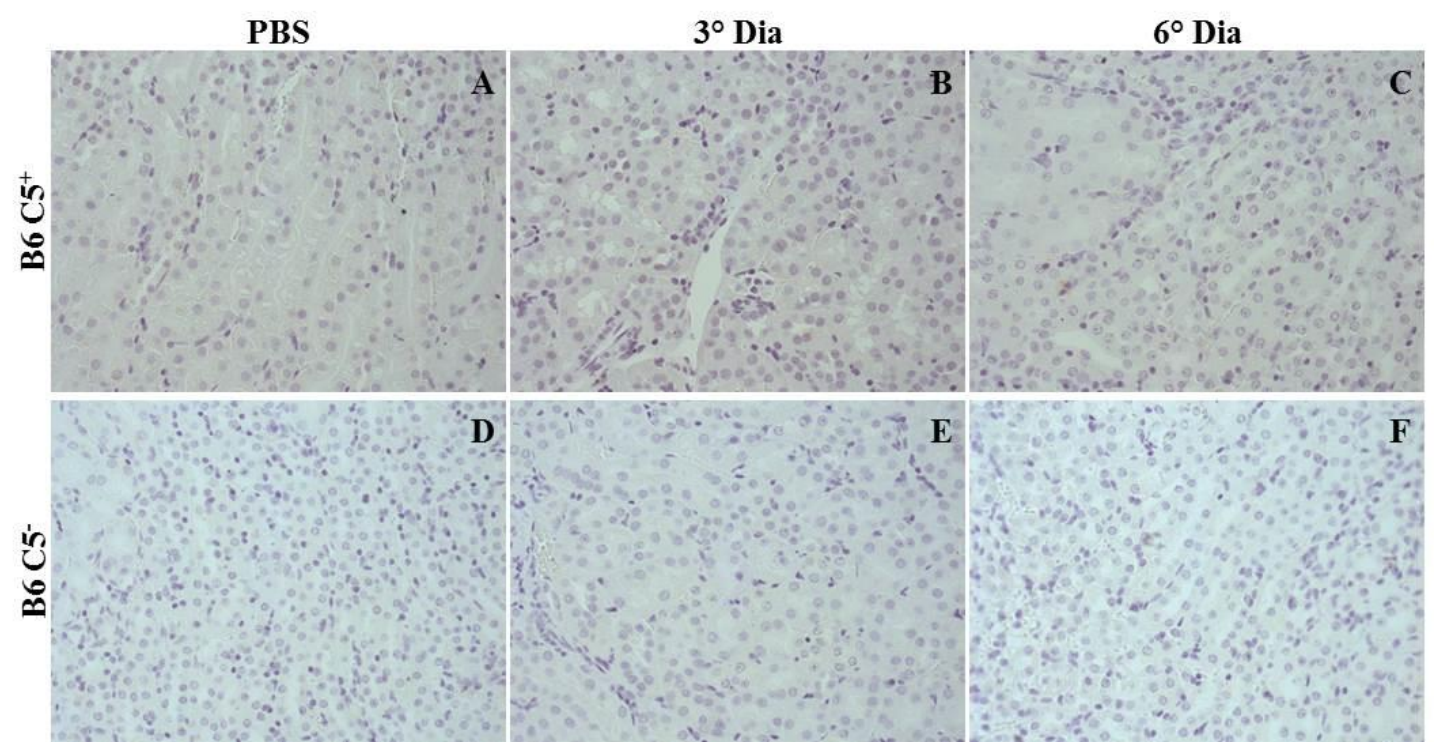

As imagens $\mathrm{A}, \mathrm{B}$ e $\mathrm{C}$ correspondem, respectivamente, ao rim de camundongos $\mathrm{B} 6 \mathrm{C}^{+}$inoculados com $\mathrm{PBS}$ ou infectados com $1,5 \times 10^{8}$ LPF e eutanasiados no terceiro ou no sexto dia de infecção. As imagens D, E e F correspondem, respectivamente, ao rim de camundongos B6 $\mathrm{C}^{-}$inoculados com PBS ou infectados com $1,5 \times 10^{8} \mathrm{LPF}$ e eutanasiados no terceiro ou no sexto dia de infecção. Aumento de 400x.

Figura 50 - Detecção de LPF por imuno-histoquímica no rim de camundongos A/J infectados com $1,5 \times 10^{8} \mathrm{LPF}$

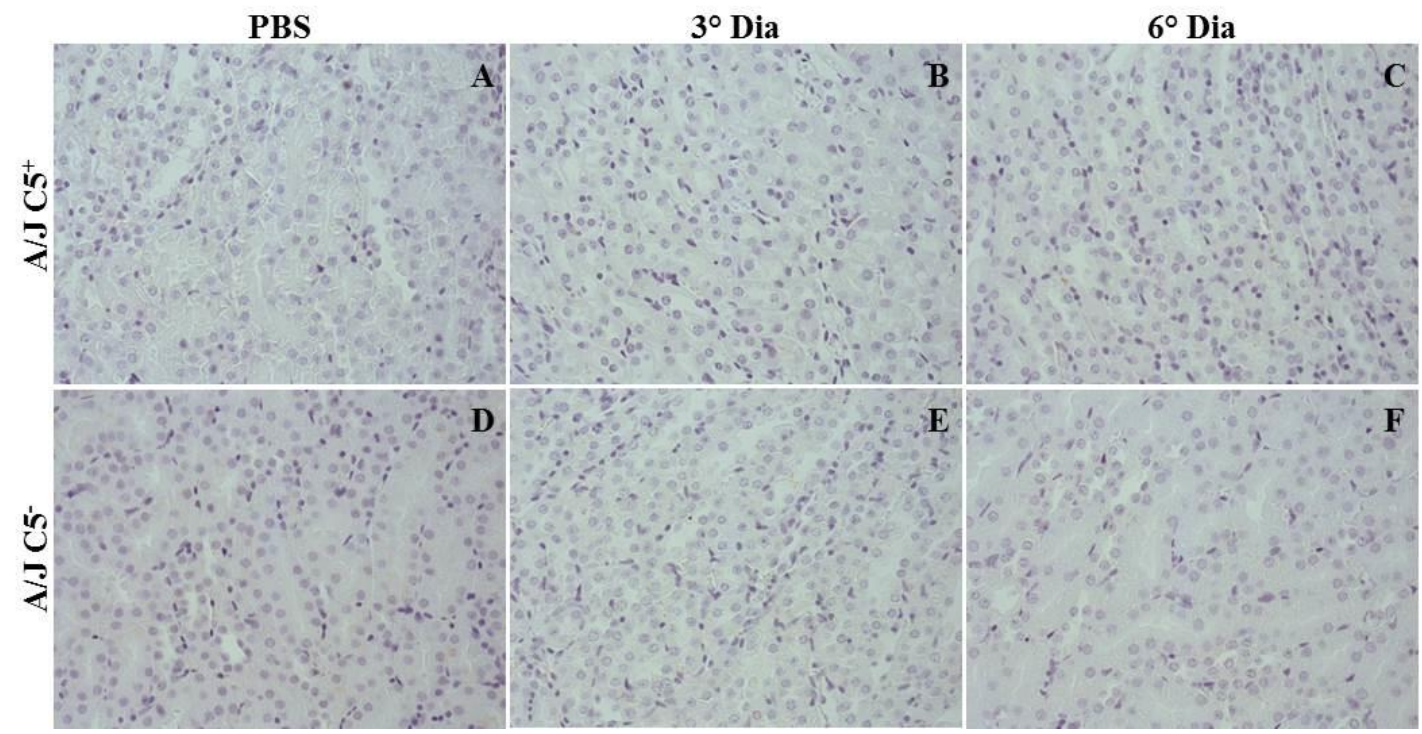

As imagens $\mathrm{A}, \mathrm{B}$ e $\mathrm{C}$ correspondem, respectivamente, ao rim de camundongos $\mathrm{A} / \mathrm{J} \mathrm{C}^{+}$inoculados com $\mathrm{PBS}$ ou infectados com $1,5 \times 10^{8}$ LPF e eutanasiados no terceiro ou no sexto dia de infecção. As imagens D, E e F correspondem, respectivamente, ao rim de camundongos A/J C5 inoculados com PBS ou infectados com $1,5 \times 10^{8} \mathrm{LPF}$ e eutanasiados no terceiro ou no sexto dia de infecção. Aumento de 400x. 


\section{DISCUSSÃO}

Desde a descoberta que o soro de pacientes convalescentes protegia cobaias dos sintomas mais graves da leptospirose (Kobayashi, 2001), resultado também observado em camundongos previamente tratados com ciclofosfamida que receberam soro anti-imune de coelho (Adler, Faine, 1976), diferentes autores têm mostrado a participação de diversos componentes do sistema imune na resposta contra a leptospira, havendo destaque principalmente para as moléculas de TLR-2 e TLR-4 e a presença de linfócitos B e consequente produção de anticorpos (Adler, Faine, 1976; Chassin et al., 2009; Que-Gewirth et al., 2004; Werts et al., 2001), sendo que a ausência deles pode levar camundongos infectados ao óbito.

Os resultados obtidos em nosso grupo e por outros pesquisadores mostram diferentes estratégias desenvolvidas pelas leptospiras patogênicas para escaparem da ação do Sistema Complemento, variando desde a ligação a proteínas reguladoras, como C4BP e FH (Barbosa et al., 2009; Castiblanco-Valencia et al., 2012; Meri et al., 2005; Silva et al., 2011), até a degradação de moléculas de C3 e seus fragmentos por enzimas secretadas no microambiente próximo às leptospiras (Fraga et al., 2014). Esses mecanismos de evasão podem explicar a maior capacidade de leptospiras patogênicas, como a LPF, em sobreviver no soro, enquanto espécies saprófitas, como a L. biflexa, são bastante sensíveis, sendo eliminadas após poucas horas de incubação (Barbosa et al., 2009; Meri et al., 2005)

Ao contrário do que inicialmente esperávamos, a infecção das linhagens B6 $\mathrm{C}^{+} \mathrm{e}$ A/J C5 com doses crescentes de LPF não acarretou em alterações significativas do número de leucócitos circulantes e nas concentrações de ALT e AST no soro e de citocinas pró e antiinflamatórias no fígado dos camundongos infectados. Ambas as linhagens foram capazes de controlar a infecção, tendo os animais infectados, independente da dose utilizada, um número de leucócitos na circulação periférica e níveis de ALT e AST no soro e de citocinas pró e antiinflamatórias no fígado semelhante ao observado nos animais dos grupos controle (PBS). A única variação encontrada foi o aumento da proporção de células PMN nos camundongos A/J C5 inoculados com $10^{9}$ LPF e B6 C5 inoculados com $10^{5}$ LPF. Devido à capacidade fagocítica apresentada por neutrófilos, é possível que esta alteração tenha ocorrido para auxiliar na eliminação das leptospiras do organismo, embora seja necessário saber se a proporção de neutrófilos está significativamente alterada para afirmar que o aumento de PMN está relacionado à fagocitose de LPF no organismo. 
O modelo de infecção por três semanas mostrou um maior número de animais $\mathrm{A} / \mathrm{J} \mathrm{C}^{-}$ portando LPF no fígado e no rim, sendo mais evidente nos animais inoculados com $10^{3}$ e $10^{5}$ LPF, sugerindo que as leptospiras conseguem sobreviver por mais tempo na linhagem A/J C5 (Tabela 4). Por outro lado, o modelo de infecção com inoculação de $10^{7}$ LPF e acompanhamento dos camundongos por três e seis dias sugere que, no início da infecção, a LPF consegue se manter melhor na linhagem B6 $\mathrm{C}^{+}$, havendo um maior número desses animais onde foram detectadas LPF vivas no fígado e no rim no terceiro dia de infecção. Essa melhor capacidade de sobrevivência da LPF na linhagem B6 $\mathrm{C}^{+}$desapareceu no sexto dia do experimento, quando foram encontradas leptospiras vivas em poucos animais, refletindo o controle da infecção nas duas linhagens nesse período (Tabela 5).

Camundongos A/J C5 ${ }^{-}$infectados com $10^{7}$ LPF apresentaram aumento significativo de leucócitos na circulação periférica no terceiro dia do experimento, sendo os valores encontrados nesse dia semelhantes ao observados na linhagem B6 $\mathrm{C}^{+}$que, embora não tenha apresentado variação na quantidade de leucócitos circulantes durante a infecção, sempre apresentou valores elevados de leucócitos na circulação. A elevação de leucócitos na circulação dos camundongos A/J $\mathrm{C}^{-}$no terceiro dia ocorreu junto do aumento da proporção de células PMN, permitindo sugerir a elevação da capacidade de fagocitose no organismo para eliminar as leptospiras presentes na circulação sanguínea. Também houve aumento da proporção de células $\mathrm{PMN}$ em camundongos $\mathrm{B} 6 \mathrm{C}^{+}$, que pode ter acontecido também para aumentar a capacidade de fagocitose e, consequentemente, levar a eliminação das leptospiras presentes no sangue.

Assim como observado no experimento de infecção por três semanas, não houve indicativo de lesão hepática devido à infecção por LPF, permanecendo constantes os níveis de ALT e AST no soro dos camundongos. Também não foram encontradas diferenças nas concentrações séricas de ureia e ácido úrico, sugerindo ausência de lesão renal em animais de ambas as linhagens.

Os resultados obtidos nesses dois modelos de infecção mostraram diferenças discretas na resposta à infecção por LPF pelas linhagens $\mathrm{A} / \mathrm{J} \mathrm{C5}^{-}$e $\mathrm{B} 6 \mathrm{C}^{+}$, o que era esperado com base em outros trabalhos, os quais apontaram diferenças na resposta à infecção por leptospiras patogênicas entre camundongos de linhagens diferentes (da Silva et al., 2009; Santos et al., 2010). Quando infectados por L. interrogans sorogrupo Icterohaemorrhagiae estirpe Cop, camundongos Balb/C não desenvolveram nefrite intersticial, ao contrário de camundongos 
A/J C5 e B6 $\mathrm{C5}^{+}$, além de possuírem menor carga parasitária no sangue após 28 dias de infecção (Santos et al., 2010).

A incapacidade em reconhecer a molécula de LPS presente na L. interrogans também resulta em alterações significativas na resposta imune contra à leptospira (Chassin et al., 2009; da Silva et al., 2009). É conhecido que o complexo formado por TLR-4, CD14 e o cofator MD2 é responsável pelo reconhecimento do LPS de bactérias Gram-negativas. Contudo, devido à variações presentes no lipídio A do LPS da leptospira, células humanas são incapazes de reconhecer essa molécula através de TLR-4, sendo o LPS da leptospira reconhecido apenas via TLR-2 (Nahori et al., 2005; Que-Gewirth et al., 2004; Werts et al., 2001). Além do reconhecimento do LPS via TLR-2, macrófagos murinos reconhecem essa molécula através do TLR-4, sendo que sua ausência está relacionada a susceptibilidade desses animais à infecção (Chassin et al., 2009; Nally et al., 2005; da Silva et al., 2009; 2012). É conhecido desde o final dos anos 90 que a linhagem $\mathrm{C} 3 \mathrm{H} / \mathrm{HeJ}$ é susceptível à leptospirose, apresentando lesões renais e pulmonares semelhantes àquelas observadas em alguns pacientes humanos (Pereira et al., 1998). O reconhecimento do papel do TLR-4 no reconhecimento do LPS (Poltorak et al., 1998) auxiliou muito no entendimento dessa susceptibilidade, sendo possível relacionar a falta desta proteína à menor capacidade de resistência de camundongos à infecção por leptospiras. A utilização de camundongos B6 nocauteados para os genes TLR-4, TLR-2 ou ambos corroborou a importância desses receptores para um resposta adequada durante a infecção, sendo os camundongos deficientes para uma dessas proteínas ou ambas suceptíveis à infecção por leptospiras patogênicas (Chassin et al., 2009).

Com a eliminação de possível interferência do fundo genético de linhagens distintas de camundongos foi possível entender melhor o papel das moléculas de TLR na leptospirose, destacando a importância desses receptores naquele modelo de estudo da resposta imune contra a leptospira (Chassin et al., 2009). Seguindo este mesmo raciocínio, utilizamos camundongos congênicos para também diferenciarmos quais variações na resposta imune são decorrentes das diferenças genéticas existentes entre as linhagens A/J e B6 daquelas influenciadas unicamente pela presença ou ausência de C5.

Diferentes trabalhos empregaram camundongos congênicos para o entendimento da importância de diferentes proteínas na resposta imune, permitindo visualizar os efeitos de sua presença ou ausência frente a diferentes tipos de infecções. Camundongos $\mathrm{C}^{+}$, como a linhagem B6, são susceptíveis ao desenvolvimento de malária cerebral, enquanto linhagens C5', como A/J, são resistentes (Patel et al., 2008). Para verificar a importância real de C5, 
foram desenvolvidas linhagens congênicas B6 $\mathrm{C5}^{-}$, resistente a este quadro clínico, e A/J $\mathrm{C}^{+}$, o qual se verificou ser susceptível, mostrando a importância de C5 no desenvolvimento deste sintoma (Patel et al., 2008). Outro exemplo da utilização de camundongos congênicos para o estudo de C5 envolve o modelo experimental de infecção por Candida albicans. Camundongos A/J C5 são considerados susceptíveis à infecção por este fungo quando inoculados por via intravenosa com esporos virulentos, apresentando elevadas concentrações de TNF- $\alpha$ e IL-6 no soro, mortalidade de $100 \% 24$ h após a inoculação e tendo maior número de unidades formadoras de colônias (UFC) no fígado, rim, pulmão e coração que animais C57B1/6J (C5 suficiente), resistentes à infecção por C. albicans (Mullick et al., 2006). Embora a resistência à infecção por $C$. albicans tenha sido relacionada aos genes de resistência à C. albicans 1 e 2 (Carg1 e Carg2) outras linhagens C5 deficientes, como AKR e $\mathrm{DBA} / 2$, tendem a ter mais UFC no rim quando infectadas, levantando a questão sobre a importância de C5 nesse modelo experimental (Ashman et al., 1996). A utilização de camundongos BcA17 (animais C5 deficientes com fundo genético C57B1/6J) permitiu concluir que a grande presença de UFC no rim e as elevadas concentrações de TNF- $\alpha$ e IL-6 no soro estão relacionadas à ausência de C5, tendo esses animais um padrão de resposta contra C. albicans semelhante à dos camundongos A/J C5' (Mullick et al., 2006).

Com o último protocolo experimental utilizado (infecção de seis dias com 1,5 $\times 10^{8} \mathrm{LPF}$ ) conseguimos distinguir entre os parâmetros analisados aqueles que são influenciados pela presença ou ausência de C5 dos que são influenciados apenas pelo tempo de infecção e as diferenças no fundo genético das linhagens B6 e A/J.

Ao contrário do observado no protocolo experimental de $10^{7} \mathrm{LPF}$, camundongos A/J apresentaram uma elevada concentração inicial de leucócitos circulantes (Figura 16A). Enquanto os camundongos B6, independentemente de C5, mantiveram constante o número de leucócitos circulantes quando infectados com 1,5 x $10^{8}$ LPF (Figura 16B), observou-se uma queda significativa dessas células no sangue periférico dos camundongos $\mathrm{A} / \mathrm{J}$ no terceiro dia. Este resultado pode estar relacionado tanto à migração de células para os órgãos afetados pela LPF, como o fígado, onde foram encontrados infiltrados leucocitários no sistema porta e nos sinusóides, quanto a menor geração de leucócitos na medula óssea devido ao aumento da concentração de IFN- $\gamma$ e TNF- $\alpha$ no soro de animais da linhagem A/J (Figura 23A e B). É conhecido que a presença de IFN- $\gamma$ e TNF- $\alpha$ em concentrações elevadas é prejudicial para a proliferação de células hematopoiéticas, reduzindo sua capacidade de replicação e aumentando a taxa de apoptose (Selleri et al., 1995). Modelos experimentais de anemia 
também mostram o papel supressor dessas citocinas sobre os progenitores hematopoiéticos (Haneline et al., 1998; Whitney et al., 1996), suportando a hipótese de relação entre a queda do número de leucócitos no terceiro dia com o aumento de IFN- $\gamma$ e TNF- $\alpha$ no soro apenas em camundongos $\mathrm{A} / \mathrm{J}$.

A análise das sub-populações leucocitárias mostrou comportamentos distintos entre os diferentes tipos celulares. A porcentagem de neutrófilos entre os granulócitos foi reduzida a partir do terceiro dia nos camundongos B6 e a partir do sexto dia nos camundongos A/J (Figura 16B), em ambos os casos independentemente de C5. Esse processo pode ter sido causado pela adesão dos neutrófilos às células endoteliais, excesso de morte celular, que pode estar relacionada ao processo de eliminação de leptospiras presentes no sangue, ou migração dos neutrófilos para os sítios de inflamação, embora essas células não tenham sido encontradas em grande quantidade nos órgãos analisados (Figura 31-41). Na literatura só foi descrito um caso de neutropenia em infecções com L. interrogans (Stefos et al., 2005), dificultado a análise do resultado obtido.

A porcentagem de monócitos variou durante a infecção de forma independente da linhagem e de C5, aumentando no terceiro dia de infecção e retornando aos valores basais no sexto dia (Figura 16C). Essa elevação no terceiro dia é semelhante ao observado em casos de sepse em pacientes hospitalares (Hoser et al., 2012), onde a quantidade de monócitos circulantes encontra-se bastante elevada, o que seria esperado devido à grande quantidade de LPF que foi injetada. A redução da proporção dessas células no sexto pode ser devido ao controle da leptospiremia no sangue, que começa a diminuir após a primeira semana de infecção. Essa redução também pode ser causada pela morte dos monócitos. Leptospiras são capazes de infectar macrófagos humanos e murinos (Merien et al., 1997) e, uma vez internalizadas, desencadeiam alterações na expressão gênica dessas células que podem leválas à apoptose (Hu et al., 2013; Merien et al., 1997; Xue et al., 2013). As alterações de expressão gênica observadas nos macrófagos retirados de organismos infectados com leptospira também ocorrem com os monócitos presentes na circulação periférica, abrindo a possibilidade do processo de morte celular programada também acontecer com esse tipo celular (Xue et al., 2013).

A porcentagem de linfócitos B varia apenas em camundongos B6, aumentando no terceiro dia e retornando aos valores iniciais no sexto dia de infecção (Figura 17), independente da linhagem. Infecções bacterianas geralmente causam o aumento do número de linfócitos B na circulação periférica (Thorley et al., 1977), podendo essa resposta do 
organismo ser causada tanto pela maturação de mais linfócitos B, aumento da migração de linfócitos B entre os tecidos linfóides como mecanismo para facilitar o encontro com o antígeno ao qual é específico, ou mesmo aumento do número de células ativadas migrando para os tecidos onde se estabelecerão pelo período em que sintetizarem imunoglobulinas. A redução da porcentagem de linfócitos B na circulação periférica no sexto dia pode ser devido à fixação das células $\mathrm{B}$ ativadas em tecido onde produzirão esses anticorpos. Em casos clínicos de sepse também é visto uma queda do número de linfócitos B no organismo, que ocorre junto do aumento de linfócitos B apoptóticos (Hotchkiss, Karl, 2003). Considerando-se a grande quantidade de leptospiras injetadas, é possível que o sistema imune dos camundongos se comporte como no exemplo da sepse, havendo aumento do número de linfócitos B apoptóticos e consequente redução de sua quantidade na circulação periférica.

Esse mesmo processo pode ocorrer com os linfócitos $\mathrm{T} \mathrm{CD}^{+}$de camundongos $\mathrm{A} / \mathrm{J}$ (Figura 18A). Primeiro há um aumento da proporção dessas células no terceiro dia de infecção, seguido pelo retorno aos valores observados nos camundongos inoculados com PBS. Esse aumento pode estar relacionado à maior produção de citocinas em camundongos A/J, onde foram detectados TNF- $\alpha$, IFN- $\gamma$ e IL-6 (Figura 23A-C), em oposição às linhagens com fundo genético B6, que não apresentaram alteração da porcentagem de linfócitos T CD4 ${ }^{+}$ na circulação (Figura 18A) e não produziram níveis expressíveis dessas citocinas no soro (Figura 23A-C).

Ao utilizarmos os camundongos congênicos pudemos observar que camundongos B6 $\mathrm{C5}^{-}$possuem menor porcentagem de linfócitos $\mathrm{T} \mathrm{CD} 4^{+}$que os camundongos $\mathrm{B} 6 \mathrm{C}^{+}$(Figura 18A), e os camundongos C5 deficientes, independente da linhagem, possuem menor proporção de linfócitos $\mathrm{T} \mathrm{CD}^{+}$que os camundongos C5 suficientes (Figura 19A). A proteína C5 é importante para a atividade de diferentes tipos celulares, inclusive linfócitos, em diferentes modelos experimentais, sendo sua ausência responsável por menor atividade lítica de linfócitos $\mathrm{T} \mathrm{CD}^{+}$e menor capacidade de síntese de citocinas por linfócitos T CD4 ${ }^{+}(\mathrm{Kim}$ et al., 2004; Moulton et al., 2007; Strainic et al., 2008). Através da interação com seus receptores presentes em linfócitos $\mathrm{T} \mathrm{CD}^{+}$, C5a fornece estímulos de sobrevivência para essas células (Strainic et al., 2008), fosforilando a molécula AKT, ativando os linfócitos e mantendo-os viáveis por mais tempo in vitro. Para verificar se este processo ocorre nas células dos camundongos B6 C5, podemos verificar os níveis de AKT fosforilado, sendo um indicativo de menor viabilidade baixos níveis dessa proteína. Essa atividade de C5 é evidente apenas no fundo genético B6, indicando participação do fundo genético. Embora não haja 
trabalhos que mostrem a participação de C5 na viabilidade de linfócitos T CD8 ${ }^{+}$, a ativação dessas células é facilitada na presença de C5a (Strainic et al., 2008). A estimulação de linfócitos $\mathrm{T} \mathrm{CD}^{+}$por células dendríticas na presença de linfócitos $\mathrm{T} \mathrm{CD}^{+}$é capaz de gerar resposta contra tecidos transplantados (Strainic et al., 2008). Caso as células dendríticas sejam deficientes para o fator acelerador do decaimento (DAF - do inglês Decay-accelerating factor), aumentando a disponibilidade de fragmentos de C5a, entre outros, no micro-ambiente celular, o processo de rejeição ocorre mesmo na ausência de linfócitos T CD4 ${ }^{+}$, mostrando a importância deste fragmento para a atividade dos linfócitos T $\mathrm{CD}^{+}$(Strainic et al, 2008). No caso dos camundongos C5 deficientes, a ausência de C5 pode ter reduzido o estímulo que os linfócitos $\mathrm{T} \mathrm{CD}^{+}$recebem para sobreviver e proliferar, resultando em menor quantidade dessas células na circulação. Contudo, é necessário realizar experimentos de viabilidade dessas células na presença de C5 e seus fragmentos para confirmar essa hipótese. Também foi visto que o estímulo de linfócitos $\mathrm{T}$ na presença de C5a reduz a porcentagem de células apoptóticas (Lalli et al., 2008). Além de inibir a apoptose, o estímulo pelo eixo C5a-C5aR auxilia na expansão celular. Linfócitos $\mathrm{T} C D 4^{+} \mathrm{C}_{5} \mathrm{aR}^{-/-}$transplantados para animais $\mathrm{Daf1}^{-/-}$ têm menor capacidade de se expandir no hospedeiro que células selvagens, indicando menor viabilidade (Lalli et al., 2008). Esse processo pode estar se repetindo com os linfócitos T $\mathrm{CD}^{+}$ativados das linhagens A/J e B6 C5 deficientes. Na ausência de C5 eles têm menor capacidade de expansão e maior taxa de apoptose, atingindo porcentagens mínimas no soro já no terceiro dia de infecção, antes das células dos camundongos C5 normais (Figura 19B).

No nosso modelo de infecção o desenvolvimento de esplenomegalia foi influenciado apenas pelo fundo genético de cada linhagem, não sendo encontradas diferenças entre camundongos $\mathrm{C}^{+}$e $\mathrm{C}^{-}$da mesma linhagem (Figura 20). Animais B6 apresentaram maior crescimento do baço no terceiro dia com regressão do tamanho do baço no sexto dia, enquanto camundongos $\mathrm{A} / \mathrm{J}$ tiveram um crescimento menos expressivo no terceiro dia, mas que se manteve até o final do experimento. Este crescimento não possui relação com o desenvolvimento da polpa branca nos animais infectados, uma vez que o sexto dia foi o período de maior atividade folicular em todas as linhagens (Figuras 37 a 39). A marcação das leptospiras por imuno-histoquímica mostrou uma intensa atividade da polpa vermelha para eliminar a LPF da circulação, o que pode justificar o crescimento do baço durante a infecção, embora não tenham sido encontradas diferenças na quantidade de marcação entre as quatro linhagens de camundongos (Figura 45 e 46). 
Uma das formas comuns de verificar a intensidade da leptospirose no organismo é através da mensuração de parâmetros bioquímicos no soro que indiquem a presença de lesão hepática, como as transaminases ALT e AST, e de atividade renal, como ureia e ácido úrico, sendo o ácido úrico importante também devido à sua capacidade antioxidante, que pode ser responsável por proteger as células de lesões decorrentes da produção de radicais de oxigênio e nitrogênio utilizados para eliminar patógenos (Adler, Faine, 1999; Erdogan et al., 2008; Freire et al., 2008; Shah, Katira, 2007). As transaminases são enzimas presentes em diversos tecidos do organismo responsáveis pela transferência do grupo amino de um aminoácido para outra molécula. A maior parte dessas enzimas é capaz de utilizar $\alpha$-cetoglutarato como molécula receptora do grupo amino, dando origem ao aminoácido glutamato que poderá doar este grupo amino para outras substâncias em diferentes vias bioquímicas, participando também da via de eliminação de nitrogênio (Nelson, Cox, 2004). Duas dessas enzimas, AST e principalmente ALT, estão presentes em grande concentração nos hepatócitos, sendo importantes indicadores de lesão hepática, uma vez que a lesão dessas células pode levar ao aumento da concentração dessas enzimas no soro através de sua liberação do citoplasma dos hepatócitos. A dosagem desses dois parâmetros, além da concentração de ureia e ácido úrico no soro das linhagens congênicas geradas em nosso laboratório mostrou a influência da presença de C5 sobre os níveis de vários deles (Bavia et al., 2014). Verificamos que a concentração sérica de AST foi minimamente influenciada pela presença de C5, estando aumentada apenas em animais fêmeas $\mathrm{C}^{+}$em relação às fêmeas $\mathrm{C}^{-}$, sugerindo uma participação reduzida de C5 no controle desse parâmetro. No entanto, camundongos A/J C5 tendem a ter maiores níveis de ALT no soro que animais $\mathrm{A} / \mathrm{J} \mathrm{C}^{+}$, sendo possível que esses animais possuam uma maior sensibilidade a lesões hepáticas. Ao mensurar a concentração de ureia e ácido úrico no soro de camundongos não infectados, verificamos que, enquanto a concentração de ureia permaneceu inalterada, a concentração de ácido úrico foi influenciada pela presença de C5, embora somente no fundo genético B6, estando em maior concentração nos animais $\mathrm{B} 6 \mathrm{C}^{+}$.

No modelo de infecção com 1,5 x $10^{8}$ LPF, as concentrações de ALT (Figura 21A), AST (Figura 21B) e ureia (Figura 22A) foram semelhantes entre todos os grupos controle, havendo diferença apenas na concentração de ureia entre camundongos com fundo genético A/J em relação aos B6. A infecção ocasionou o aumento dos níveis de ALT no terceiro dia nos camundongos A/J, independentemente de haver ou não C5 no organismo, e o aumento de AST somente na linhagem A/ $\mathrm{C}^{+}$, indicando que, neste modelo, a presença de $\mathrm{C} 5$ pode ter 
facilitado a lesão de hepatócitos nos camundongos A/J. Embora não tenham sido encontradas diferenças estatísticas, camundongos B6 C5 apresentaram aumento nas concentrações de ALT e AST no terceiro dia de infecção, enquanto os níveis dessas enzimas permaneceram mais estáveis em B6 $\mathrm{C}^{+}$, o que pode ser um indicativo de maior sensibilidade na linhagem C5', embora sejam necessários novos experimentos para comprovar essa afirmação. A concentração de ácido úrico (Figura 22B) teve comportamentos distintos entre as linhagens A/J e B6. Enquanto em A/J os níveis de ácido úrico decresceram no sexto dia de infecção em relação ao terceiro dia, nas linhagens B6 houve um grande aumento de sua concentração no soro no sexto dia.

Foram encontradas diferenças nas concentrações de algumas citocinas entre animais $\mathrm{C}^{+}$e $\mathrm{C} 5^{-}$no nosso modelo de infecção com LPF, sendo parte dessas alterações influenciada pelo fundo genético de cada linhagem, enquanto parte das alterações ocorreu de forma semelhante em A/J e B6. Camundongos C5 deficientes, independente do fundo genético, possuem menores concentrações de IL-10, IL-1 $\beta$, IL-12p40 e IL-12p70 no fígado no $6^{\circ}$ dia de infecção que animais C5 normais (Figuras 25 e 26). Trabalhos anteriores mostraram que a ausência de C5 (Moulton et al., 2007) ou o bloqueio de C5aR (Clark et al., 2006) não afeta os níveis basais de citocinas de camundongos $\mathrm{C} 5$ deficientes, embora resultem em menor síntese de diferentes citocinas, como IL-6 e IL-12p40, quando os camundongos ou linfócitos T desses animais são estimulados. A redução da quantidade da subunidade p40 de IL-12 pode levar à menor produção de IL-12p70, uma vez que essa citocina é formada pela ligação covalente das subunidades p35 e p40 (Hamza et al., 2010; Lasek et al., 2014). Também foi sugerido recentemente que C5 é importante para a maturação e liberação de IL-1 $\beta$ por meio da indução do inflamassoma NLRP3 (Laudisi et al., 2013), sendo que na sua ausência a produção dessa citocina é significativamente reduzida. A menor quantidade de IL-10 pode estar relacionada aos menores níveis de IL-1 $\beta$, uma vez que IL-1 $\beta$ é capaz de regular a síntese de IL-10 e, na sua ausência, há menor produção de IL-10 por monócitos estimulados (Foey et al., 1998). Essa variação conjunta de IL-10 e IL-1 $\beta$ também já foi observada em modelos experimentais de sepse, onde a ausência de C5 resulta em menor síntese de ambas as citocinas (Flierl et al., 2008).

Os níveis de TNF, IL-6, IL-10, IL-12p40 e IL-12p70 no rim dos camundongos B6 C5 também são menores que o observado nos camundongos $\mathrm{C}^{+}$(Figuras 27 e 28), sugerindo que a ausência de C5 no rim de animais C57B1/6 pode acarretar nos mesmos efeitos observados no fígado dos camundongos infectados pela LPF. Camundongos previamente 
tratados com antagonistas de C5aR submetidos a processo de inflamação estéril dos membros anteriores apresentam menores concentrações de TNF- $\alpha$, IL-1 $\beta$ e IL-6 que os animais não tratados (Clark et al., 2006). Entretanto, em oposição ao que esperávamos, camundongos A/J C5 $5^{-}$possuem maiores concentrações de TNF e IL-6 no rim que os animais $\mathrm{C}^{+}$(Figura 27A e B). Esse aumento da concentração de citocinas na ausência de C5 também foi observado em modelos de infecção com C. albicans (Mullick et al., 2011) e de asma (Lajoie et al., 2010). Camundongos A/J, naturalmente $\mathrm{C} 5$ deficientes, e camundongos B6 deficientes para $\mathrm{C} 5$ ou $\mathrm{C} 5 \mathrm{aR}$ apresentam maiores concentrações de diferentes citocinas no soro que camundongos C5 e/ou C5aR suficientes, entre elas IL-6, quando infectados com C. albicans (Mullick et al., 2011). Camundongos A/J C5 e Balb/C C5aR deficientes também produzem maiores níveis de IL-23 que camundongos $\mathrm{C} 3 \mathrm{H} / \mathrm{HeJ}$ e Balb/C C5 suficientes, respectivamente (Lajoie et al., 2010).

Assim como observado em outros trabalhos (Chassin et al., 2009; da Silva et al., 2012), foram encontradas lesões hepáticas nos camundongos infectados, sendo evidente o aumento do número de células de Küpffer nos sinusóides e o surgimento de infiltrados leucocitários no fígado (Figuras 31 e 32). Outras lesões como áreas de necrose e destrabeculação dos hepatócitos também foram observadas, embora em menor frequência. Também foram encontradas células mitóticas nas quatro linhagens infectadas, indicando lesões hepatocelulares mesmo nos animais onde não foram detectadas regiões necrosadas (Figuras 31B, 32C e 32F). As leptospiras são capazes de infectar hepatócitos, ocasionando a ativação do processo de apoptose (Merien et al., 1998). Embora tenha sido detectado um pico de apoptose no segundo dia após o contato das leptospiras com os hepatócitos (Merien et al., 1998), esse resultado é observado por vários dias, facilitando a observação de células mitóticas em todas as linhagens até o sexto dia para repor a célula perdida.

Diferentes estudos mostram que C5 é importante para o processo de regeneração hepática após diversos tipos de lesão (Strey et al., 2003). Camundongos C5 deficientes têm maior sensibilidade à diferentes estímulos e, uma vez lesionados, apresentam maior dificuldade de recuperação (Markiewski et al., 2009; Mastellos et al., 2001). No nosso trabalho observamos que, ao contrário das demais linhagens, camundongos B6 $\mathrm{C}^{+}$ apresentam células mitóticas no fígado a partir do terceiro dia de infecção. C5 é importante para a síntese e liberação de fatores de crescimento no tecido lesionado, estimulando a proliferação celular (Markiewski et al., 2009). O resultado obtido está de acordo com essa informação, embora C5 só tenha sido importante no fundo genético B6. Contudo, além desse 
papel protetor, C5 também é responsável por aumentar o grau de lesão em diferentes modelos experimentais (Pritchard et al., 2007). Devido a capacidade de C5a estimular e atrair diversos tipos celulares para o sítio de inflamação (Liu et al., 2013; Mashruwala et al., 2011; Mollnes et al., 2002; Moulton et al., 2007; Snyderman et al., 1971; Ward, Zvaifler, 1971), o potencial de lesão tecidual é aumentado na sua presença. A observação das lesões hepáticas refletem isso quando analisamos somente o fundo genético B6. Animais B6 C5 ${ }^{+}$apresentaram maior variedade de lesões e em maior intensidade que animais $\mathrm{B} 6 \mathrm{C}^{-}$, sugerindo maior proteção desse órgão na ausência de C5. É conhecido que camundongos B6 possuem um perfil imunológico mais pró-inflamatório que camundongos A/J (Caspi, 2002; Mills et al., 2000), o que pode explicar o fato de não serem encontradas diferenças nas lesões observadas no fígado de camundongos A/J C5 ${ }^{+}$e $\mathrm{A} / \mathrm{J} \mathrm{C}^{-}$.

A detecção de LPF no fígado dos camundongos não mostrou diferenças significativas entre as linhagens, independentemente de haver ou não expressão de C5, nem entre os dias de infecção. Devido às variações da marcação entre os camundongos, serão realizadas reações de RT-PCR para determinar com maior precisão se há diferença entre as linhagens e entre animais $\mathrm{C}^{+}$e $\mathrm{C5}^{-}$na capacidade de eliminar a LPF.

Mesmo sendo linhagens de camundongos resistentes à leptospirose, foi possível observar lesões pulmonares devido a infecção, sendo as lesões semelhantes ao observado por da Silva et alii (2012). Com exceção de um camundongo que apresentou hemorragia pulmonar, a lesão predominante foi caracterizada pelo espessamento do septo alveolar, podendo ocorrer em uma região isolada do pulmão ou estar distribuida ao longo do corte histológico. A linhagem A/J foi a única que apresentou melhora da lesão pulmonar no sexto dia de infecção, enquanto nas demais linhagens, principalmente com fundo genético B6, foram encontrados camundongos com lesões pulmonares. Devido à presença de lesões pulmonares esperávamos que houvesse grande quantidade de LPF nos septos alveolares. No entanto, isso não se confirmou por imunohistoquímica, não sendo as lesões causadas diretamente pelas leptospiras.

O baço dos camundongos mostrou ser um local de muita atividade celular durante a infecção. Além do seu crescimento em ambas as linhagens (Figura 20), foi mostrado ser um órgão bastante ativo na eliminação das leptospiras da circulação, sendo encontrado traços da LPF principalmente na polpa vermelha, onde estão situados os macrófagos responsáveis pela fagocitose de antígenos presentes no sangue. A polpa branca teve alterações que mostraram primeiramente a ativação e proliferação dos linfócitos B presentes em sua periferia, indicando 
o início de uma resposta dependente de anticorpos, que posteriormente muda para uma resposta inflamatória com perfil Th1 ao haver proliferação dos linfócitos T presentes ao redor da artéria centrofolicular. Também foi notado que, quanto maior a atividade da zona $\mathrm{T}$ do baço, menor era a presença de leptospiras neste órgão, sugerindo uma associação entre a atividade desse órgão e a velocidade com que as leptospiras são eliminadas do organismo.

Por fim, não foi possível observar lesões renais nem detectar leptospiras no rim dos camundongos em nosso modelo experimental. Apesar de ser um órgão importante para a infecção por ser um local onde a leptospira se fixa e é eliminada com a urina, aparentemente elas não conseguiram colonizar este órgão na primeira semana de infecção, sendo possível que, para o sorovar utilizado em nosso laboratório, sejam necessários mais dias para ela atingir o rim.

Nossos resultados mostraram que, neste modelo de infecção com L. interrogans, a influência exercida pelo fundo genético dos camundongos e pelo tempo de infecção sobre as variações da resposta imune é preponderante em relação à presença ou ausência de C5 no organismo. Devido às diferentes ações desempenhadas por C5, sua ausência acarretou em mudanças em alguns parâmetros, como a redução das porcentagens de linfócitos $\mathrm{T} \mathrm{CD} 4^{+}$e $\mathrm{T} \mathrm{CD}^{+}$na circulação periférica, que podem levar a maiores dificuldades desses camundongos em responder à infecções por outros patógenos. Contudo, esta variação não alterou significativamente a capacidade dos camundongos em controlar a infecção causada pela LPF, sugerindo uma importância menor de C5 neste modelo de infecção. 


\section{CONCLUSÕES}

O protocolo utilizado para preparar os inóculos contendo LPF mantém a capacidade dessas bactérias em causar sintomas clínicos da doença nos hamsters, animais susceptíveis à infecção, e alterações fisiológicas nas quatro linhagens de camundongos utilizadas nesse projeto.

O acompanhamento dos camundongos por seis dias permitiu uma melhor observação das variações entre os animais infectados daqueles inoculados com PBS, sendo por isso escolhido para o experimento com os congênicos ao invés do modelo de três semanas de infecção.

A infecção com $1,5 \times 10^{8}$ LPF mostrou diferenças relacionadas aos fundos genéticos $\mathrm{A} / \mathrm{J}$ e B6, à presença ou ausência de C5 e a ambos. Os parâmetros que sofreram maior influência de C5 foram:

1. Linfócitos $\mathrm{T} \mathrm{CD}^{+}$: camundongos $\mathrm{B} 6 \mathrm{C}^{-}$possuem menor porcentagem dessas células na circulação periférica que camundongos B6 $\mathrm{C}^{+}$;

2. Linfócitos $\mathrm{T} \mathrm{CD}^{+}$: camundongos $\mathrm{C}^{-}$possuem menor porcentagem dessas células na circulação periférica que camundongos $\mathrm{C}^{+}$, independente do fundo genético;

3. Linfócitos $\mathrm{T} \mathrm{CD}^{+}$ativados: a redução da porcentagem dessas células na circulação periférica é mais rápida nos animais $\mathrm{C5}^{\circ}$;

4. Concentração de citocinas: Camundongos B6 C5 ${ }^{+}$têm maior concentração de TNF, IL-6, IL-10, IL-12p40 e IL-12p70 no rim que camundongos B6 C5;, enquanto animais A/J C5 ${ }^{-}$apresentam maiores concentrações de TNF e IL-6 no rim que $\mathrm{A} / \mathrm{J} \mathrm{C}^{+}$. Camundongos $\mathrm{C}^{-}$também possuem menores níveis IL-1 $\beta$, IL10, IL-12p40 e IL-12p70 no fígado no sexto dia de infecção;

5. Lesão hepática: Camundongos $\mathrm{B} 6 \mathrm{C}^{+}$desenvolvem lesões mais intensas no terceiro dia que camundongos B6 $\mathrm{C5}^{-}$, sendo os únicos a apresentar áreas de necrose e células mitóticas no terceiro dia de infecção.

A concentração de leucócitos na circulação periférica permaneceu constante nos camundongos B6, reduzindo no terceiro dia apenas nos camundongos A/J, independentemente de C5. Para nossa surpresa, diminuiu a porcentagem de neutrófilos durante a infecção em A/J e B6, independente de C5, enquanto a porcentagem de monócitos aumentou no terceiro dia de experimento em todas as linhagens. A porcentagem de linfócitos B aumentou apenas nos camundongos B6, permanecendo constante nos camundongos A/J, independente de C5. 
O desenvolvimento de esplenomegalia aconteceu independentemente de $\mathrm{C} 5$, sendo mais intensa no terceiro dia de infecção nos camundongos B6.

Camundongos A/J, independente de C5, apresentaram elevação da concentração de ALT no soro, enquanto apenas camundongos $\mathrm{A} / \mathrm{J} \mathrm{C}^{+}$tiveram aumento dos níveis séricos de AST. A concentração de ureia no soro estava reduzida no terceiro dia de infecção em todas as linhagens, sendo parcialmente restabelecida no sexto dia. A concentração de ácido úrico aumentou significativamente no sexto dia nos camundongos B6, independentemente de C5.

Somente camundongos A/J apresentaram aumento significativo das concentrações de TNF- $\alpha$, IFN- $\gamma$ e IL-6 no soro no terceiro dia de infecção, independente de C5.

O fígado e o baço foram os principais órgãos afetados pela infecção com LPF. Todas as linhagens tiveram indivíduos com aumento do número de células no sinusóides hepáticos e desenvolvimento de infiltrados leucocitários e de células mitóticas, um indicativo de lesão hepatocelular seguida de regeneração tecidual. O baço mostrou uma tendência de ativação da região perifolicular, rica em linfócitos $\mathrm{B}$, com posterior ativação da região centrofolicular, rica em linfócitos $\mathrm{T}$, permanecendo as duas regiões bastante ativas no sexto dia de infecção. A detecção de LPF nesses órgãos foi bastante intensa. Contudo, não foi possível detectar diferenças significativas na quantidade de leptospiras entre camundongos A/J e B6, independente de C5, sendo necessária a realização de reações de RT-PCR para afirmar se há ou não diferença na capacidade das diferentes linhagens de camundongos em eliminar aLPF do organismo.

Todas as linhagens desenvolveram lesões pulmonares durante a infecção. No entanto, da mesma forma que no rim, que não apresentou alterações histopatológicas, não foram detectadas leptospiras no pulmão. 


\section{REFERÊNCIAS*}

Adler B, Faine S. Susceptibility of mice treated with cyclophosphamide to lethal infection with Leptospira interrogans Sorovar Pomona. Infect Immun. 1976;14(3):703-8.

Adler B, Faine, S. Host immunological mechanisms in the resistance of mice to leptospiral infections. Infect Immun. 1977;17(1):67-72.

Adler B, de la Peña Moctezuma A. Leptospira and leptospirosis. Vet Microbiol. 2010;140(34):287-96.

Aleshin AE, Schraufstatter IU, Stec B, Bankston LA, Liddington RC, DiScipio RG. Structure of complement C6 suggests a mechanism for initiation and unidirectional, sequential assembly of membrane attack complex (MAC). J Biol Chem. 2012;287(13):10210-22.

Ashman RB, Fulurija A, Papadimitriou JM. Strain-dependent differences in host response to Candida albicans infection in mice are related to organ susceptibility and infectious load. Infect Immun. 1996;64(5):1866-9.

Barbosa AS, Abreu PA, Vasconcellos SA, Morais ZM, Gonçales AP, Silva AS, et al. Immune evasion of leptospira species by acquisition of human complement regulator C4BP. Infect Immun. 2009;77(3):1137-43.

Barbosa AS, Monaris D, Silva LB, Morais ZM, Vasconcellos SA, Cianciarullo AM, et al. Functional characterization of LcpA, a surface-exposed protein of Leptospira spp. that binds the human complement regulator C4BP. Infect Immun. 2010;78(7):3207-16.

Bavia L, de Castro IA, Massironi SMG, Isaac L. Basal physiological parameters of two congenic mice strains: C5 deficient C57BL/6 and C5 sufficient A/J. Immunol Lett. 2014 May-Jun;159(1-2):47-54.

Bharti AR, Nally JE, Ricaldi JN, Matthias MA, Diaz MM, Lovett MA, et al. Leptospirosis: a zoonotic disease of global importance. Lancet Infect Dis. 2003;3(12):757-71.

Bokisch VA, Müller-Eberhard HJ. Anaphylatoxin inactivator of human plasma: its isolation and characterization as a carboxypeptidase. J Clin Invest. 1970;49(12):2427-36.

Cain SA, Coughlan T, Monk PN. Mapping the ligand-binding site on the C5a receptor: arginine 74 of $\mathrm{C} 5 \mathrm{a}$ contacts aspartate282 of the $\mathrm{C} 5 \mathrm{a}$ receptor. Biochemistry. 2001;40(46):14047-52.

Caspi RR. Th1 and Th2 responses in pathogenesis and regulation of experimental autoimmune uveoretinitis. Int Rev Immunol. 2002 Mar-Jun;21(2-3):197-208.

\footnotetext{
*De acordo com:

Internatonal Commitee of Medical Journal Editors. Uniform requirements for manuscripts submited to biomedical journals. [2011 July 15]. Available from:http://www.nlm.nih.gov/bsd/uniform_requirements.html.
} 
Castiblanco-Valencia MM, Fraga TR, Silva LB, Monaris D, Abreu PA, Strobel S, et al. Leptospiral immunoglobulin-like proteins interact with human complement regulators factor H, FHL-1, FHR-1, and C4BP. J Infect Dis. 2012;205(6):995-1004.

Chagas-Junior AD, McBride AJ, Athanazio DA, Figueira CP, Medeiros MA, Reis MG, et al. An imprint method for detecting leptospires in the hamster model of vaccine-mediated immunity for leptospirosis. J Med Microbiol. 2009;58(Pt 12):1632-7.

Chassin C, Picardeau M, Goujon JM, Bourhy P, Quellard N, Darche S, et al. TLR4- and TLR2-Mediated B cell responses control the clearance of the bacterial pathogen, Leptospira interrogans. J Immunol. 2009;183(4):2669-77.

Chen NJ, Mirtsos C, Suh D, Lu YC, Lin WJ, McKerlie C, et al. C5L2 is critical for the biological activities of the anaphylatoxins C5a and C3a. Nature. 2007 Mar 8;446(7132):2037.

Clark JD, Qiao Y, Li X, Shi X, Angst MS, Yeomans DC. Blockade of the complement C5a receptor reduces incisional allodynia, edema, and cytokine expression. Anesthesiology. 2006;104(6):1274-82.

Craig SB. Host Responses to Leptospiral Infections [Ph. D. thesis]. Queensland: University of the Sunshine Coast; 2010.

da Silva JB, Ramos TM, de Franco M, Paiva D, Ho PL, Martins EA, et al. Chemokines expression during Leptospira interrogans sorovar Copenhageni infection in resistant BALB/C and susceptible C3H/HeJ mice. Microb Pathog. 2009;47(2):87-93.

da Silva JB1, Carvalho E, Covarrubias AE, Ching AT, Mattaraia VG, Paiva D, et al. Induction of TNF-alfa and CXCL-2 mRNAs in different organs of mice infected with pathogenic Leptospira. Microb Pathog. 2012;52(4):206-16.

D'Eustachio P, Kristensen T, Wetsel RA, Riblet R, Taylor BA, Tack BF. Chromosomal location of the genes encoding complement components $\mathrm{C} 5$ and factor $\mathrm{H}$ in the mouse. $\mathrm{J}$ Immunol. 1986;137(12):3990-5

Dobrina A, Pausa M, Fischetti F, Bulla R, Vecile E, Ferrero E, et al. Cytolytically inactive terminal complement complex causes transendothelial migration of polymorphonuclear leukocytes in vitro and in vivo. Blood. 2002;99(1):185-92.

Eglite S, Plüss K, Dahinden CA. Requirements for C5a receptor-mediated IL-4 and IL-13 production and leukotriene C4 generation in human basophils. J Immunol. 2000;165(4):21839.

el-Lati SG, Dahinden CA, Church MK. Complement peptides C3a- and C5a-induced mediator release from dissociated human skin mast cells. J Invest Dermatol. 1994;102(5):8036.

Erdogan HM, Karapehlivan M, Citil M, Atakisi O, Uzlu E, Unver A. Serum sialic acid and oxidative stress parameters changes in cattle with leptospirosis. Vet Res Commun. 2008;32(4):333-9. 
Faine S, Adler B, Bolin C, Perolat P. Leptospira and leptospirosis. 2nd. ed. Melbourne: MediSci; 1999. 296 p.

Flierl MA, Rittirsch D, Nadeau BA, Day DE, Zetoune FS, Sarma JV, Huber-Lang MS, Ward PA. Functions of the complement components C3 and C5 during sepsis. FASEB J. 2008;22(10):3483-90.

Foey AD, Parry SL, Williams LM, Feldmann M, Foxwell BM, Brennan FM. Regulation of monocyte IL-10 synthesis by endogenous IL-1 and TNF-alpha: role of the p38 and p42/44 mitogen-activated protein kinases. J Immunol. 1998;160(2):920-8.

Fraga TR, Barbosa AS, Isaac L. Leptospirosis: Aspects of innate immunity, immunopathogenesis and immune evasion from the complement system. Scand J Immunol. 2011;73(5):408-19.

Fraga TR, Courrol DD, Castiblanco-Valencia MM, Hirata IY, Vasconcellos SA, Juliano L, et al. Immune evasion by pathogenic leptospira strains: the secretion of proteases that directly cleave complement proteins. J Infect Dis. 2014;209(6):876-86.

Freire IMA, Varges R, Lilenbaum W. Blood urea nitrogen and creatinine levels in dogs with acute leptospirosis determined by Icterohaemorrhagiae serogroup. Cienc Rural. 2008;38(4):1172-5

Gao H, Neff TA, Guo RF, Speyer CL, Sarma JV, Tomlins S, et al. Evidence for a functional role of the second C5a receptor C5L2. FASEB J. 2005 Jun;19(8):1003-5.

Gerard NP, Lu B, Liu P, Craig S, Fujiwara Y, Okinaga S, et al. An anti-inflammatory function for the complement anaphylatoxin C5a-binding protein, C5L2. J Biol Chem. 2005 Dec 2;280(48):39677-80.

Guerreiro H, Croda J, Flannery B, Mazel M, Matsunaga J, Galvão Reis M, et al. Leptospiral proteins recognized during the humoral immune response to leptospirosis in humans. Infect Immun. 2001;69(8):4958-68.

Guo RF, Ward PA. Role of C5a in inflammatory responses. Annu Rev Immunol. 2005;23:821-52.

Hamza T, Barnett JB, Li B. Interleukin 12 a key immunoregulatory cytokine in infection applications. Int J Mol Sci. 2010;11(3):789-806.

Haviland DL, Haviland JC, Fleischer DT, Wetsel RA. Structure of the murine fifth complement component (C5) gene. A large, highly interrupted gene with a variant donor splice site and organizational homology with the third and fourth complement component genes. J Biol Chem. 1991;266(18):11818-25.

Hoser GA, Skirecki T, Złotorowicz M, Zielińska-Borkowska U, Kawiak J. Absolute counts of peripheral blood leukocyte subpopulations in intraabdominal sepse and pneumonia-derived sepse: a pilot study. Folia Histochem Cytobiol. 2012;50(3):420-6. 
Hotchkiss RS, Karl IE. The pathophysiology and treatment of sepse. N Engl J Med. 2003;348(2):138-50.

Hu W, Ge Y, Ojcius DM, Sun D, Dong H, Yang XF, et al. p53 signalling controls cell cycle arrest and caspase-independent apoptosis in macrophages infected with pathogenic Leptospira species. Cell Microbiol. 2013;15(10):1642-59.

Inada R, Ido Y. Preliminary report on the identification of a causative spirochete (a new species) of Weil's disease (in Japanese). Fukuoka Ikadaigaku Zasshi (Fukuoka acta med.) 1915;8:368-9.

Kim AH, Dimitriou ID, Holland MC, Mastellos D, Mueller YM, Altman JD, et al. Complement C5a receptor is essential for the optimal generation of antiviral CD8+ $\mathrm{T}$ cell responses. J Immunol. 2004;173(4):2524-9.

Ko AI, Goarant C, Picardeau M. Leptospira: the dawn of the molecular genetics era for an emerging zoonotic pathogen. Nat Rev Microbiol. 2009;7(10):736-47.

Kobayashi Y. Discovery of the causative organism of Weil's disease: historical view. J Infect Chemother. 2001;7(1):10-5.

Lajoie S, Lewkowich IP, Suzuki Y, Clark JR, Sproles AA, Dienger K, Budelsky AL, WillsKarp M. Complement-mediated regulation of the IL-17A axis is a central genetic determinant of the severity of experimental allergic asthma. Nat Immunol. 2010;11(10):928-35.

Lalli PN, Strainic MG, Yang M, Lin F, Medof ME, Heeger PS. Locally produced C5a binds to $\mathrm{T}$ cell-expressed $\mathrm{C} 5 \mathrm{aR}$ to enhance effector $\mathrm{T}$-cell expansion by limiting antigen-induced apoptosis. Blood. 2008;112(5):1759-66.

Lau C, Smythe L, Weinstein P. Leptospirosis: an emerging disease in travellers. Travel Med Infect Dis. 2010;8(1):33-9.

Lasek W, Zagożdżon R, Jakobisiak M. Interleukin 12: still a promising candidate for tumor immunotherapy? Cancer Immunol Immunother. 2014;63(5):419-35.

Laudisi F, Spreafico R, Evrard M, Hughes TR, Mandriani B, Kandasamy M, et al. Cutting edge: the NLRP3 inflammasome links complement-mediated inflammation and IL-1 $\beta$ release. J Immunol. 2013;191(3):1006-10.

Levett PN. Leptospirosis. Clin Microbiol Rev. 2001;14(2):296-326.

Liu T, Xu G, Guo B, Fu Y, Qiu Y, Ding Y, et al. An essential role for C5aR signaling in the optimal induction of a malaria-specific CD4+ T cell response by a whole-killed blood-stage vaccine. J Immunol. 2013;191(1):178-86.

Lorenzo-Morales J. Zoonosis. Rijeka: InTech; 2012. 436 p.

Manthey HD, Woodruff TM, Taylor SM, Monk PN. Complement component 5a (C5a). Int J Biochem Cell Biol. 2009;41(11):2114-7. 
Marder SR, Chenoweth DE, Goldstein IM, Perez HD. Chemotactic responses of human peripheral blood monocytes to the complement-derived peptides C5a and C5a des Arg. J Immunol. 1985;134(5):3325-31.

Marinho M, Oliveira-Júnior IS, Monteiro CM, Perri SH, Salomão R. Pulmonary disease in hamsters infected with Leptospira interrogans: histopathologic findings and cytokine mRNA expressions. Am J Trop Med Hyg. 2009;80(5):832-6.

Markiewski MM, DeAngelis RA, Strey CW, Foukas PG, Gerard C, Gerard N, et al. The regulation of liver cell survival by complement. J Immunol. 2009 May 1;182(9):5412-8.

Marotto PC, Nascimento CM, Eluf-Neto J, Marotto MS, Andrade L, Sztajnbok J, et al. Acute lung injury in leptospirosis: clinical and laboratory features, outcome, and factors associated with mortality. Clin Infect Dis. 1999;29(6):1561-3.

Mashruwala MA, Smith AK, Lindsey DR, Moczygemba M, Wetsel RA, Klein JR, et al. A defect in the synthesis of Interferon- $\gamma$ by the T cells of Complement-C5 deficient mice leads to enhanced susceptibility for tuberculosis. Tuberculosis. 2011;91 Suppl 1:S82-9.

Mastellos D, Papadimitriou JC, Franchini S, Tsonis PA, Lambris JD. A novel role of complement: mice deficient in the fifth component of complement (C5) exhibit impaired liver regeneration. J Immunol. 2001 Feb 15;166(4):2479-86.

Meri T, Murgia R, Stefanel P, Meri S, Cinco M. Regulation of complement activation at the C3-level by serum resistant leptospires. Microb Pathog. 2005;39(4):139-47.

Merien F, Baranton G, Perolat P. Invasion of Vero cells and induction of apoptosis in macrophages by pathogenic Leptospira interrogans are correlated with virulence. Infect Immun. 1997;65(2):729-38.

Merien F, Truccolo J, Rougier Y, Baranton G, Perolat P. In vivo apoptosis of hepatocytes in guinea pigs infected with Leptospira interrogans serovar icterohaemorrhagiae. FEMS Microbiol Lett. 1998;169(1):95-102.

Mills CD, Kincaid K, Alt JM, Heilman MJ, Hill AM. M-1/M-2 macrophages and the Th1/Th2 paradigm. J Immunol. 2000 Jun 15;164(12):6166-73.

Mollnes TE, Brekke OL, Fung M, Fure H, Christiansen D, Bergseth G, et al. Essential role of the $\mathrm{C} 5 \mathrm{a}$ receptor in $\mathrm{E}$ coli-induced oxidative burst and phagocytosis revealed by a novel lepirudin-based human whole blood model of inflammation. Blood. 2002;100(5):1869-77.

Monk PN, Scola AM, Madala P, Fairlie DP. Function, structure and therapeutic potential of complement C5a receptors. Br J Pharmacol. 2007;152(4):429-48.

Morley BJ, Walport MJ. The complement factsbook. London: Academic Press; 2000. 240 p.

Moulton RA, Mashruwala MA, Smith AK, Lindsey DR, Wetsel RA, Haviland DL, et al. Complement C5a anaphylatoxin is an innate determinant of dendritic cell-induced Th1 immunity to Mycobacterium bovis BCG infection in mice. J Leukoc Biol. 2007;82(4):956-67.

Mullick A, Tremblay J, Leon Z, Gros P. A novel role for the fifth component of complement (C5) in cardiac physiology. PLoS One. 2011;6(8):e22919. 
Nahori MA, Fournié-Amazouz E, Que-Gewirth NS, Balloy V, Chignard M, Raetz CR, et al. Differential TLR recognition of leptospiral lipid A and lipopolysaccharide in murine and human cells. J Immunol. 2005 Nov 1;175(9):6022-31.

Nataf S, Davoust N, Ames RS, Barnum SR. Human T cells express the C5a receptor and are chemoattracted to C5a. J Immunol. 1999;162(7):4018-23.

Nally JE, Fishbein MC, Blanco DR, Lovett MA. Lethal infection of C3H/HeJ and C3H/SCID mice with an isolate of Leptospira interrogans serovar copenhageni. Infect Immun. 2005;73(10):7014-7.

Nelson DL, Cox MM. Principles of biochemistry. 4th ed. New York: W. H. Freeman; 2004. $1100 \mathrm{p}$.

Organização Mundial da Saúde. Leptospirosis worldwide. Wkly Epidemiol Rec. 1999;74(29):237-42.

Patel SN, Berghout J, Lovegrove FE, Ayi K, Conroy A, Serghides L, et al. C5 deficiency and C5a or C5aR blockade protects against cerebral malaria. J Exp Med. 2008;205(5):1133-43.

Pereira MM, Andrade J, Marchevsky RS, Ribeiro dos Santos R. Morphological characterization of lung and kidney lesions in $\mathrm{C} 3 \mathrm{H} / \mathrm{HeJ}$ mice infected with Leptospira interrogans serovar icterohaemorrhagiae: defect of CD4+ and CD8+ T-cells are prognosticators of the disease progression. Exp Toxicol Pathol. 1998;50(3):191-8.

Picardeau M. Diagnosis and epidemiology of leptospirosis. Med Mal Infect. 2013;43(1):1-9.

Poltorak A, Smirnova I, He X, Liu MY, Van Huffel C, McNally O, et al. Genetic and physical mapping of the Lps locus: identification of the toll-4 receptor as a candidate gene in the critical region Blood Cells Mol Dis. 1998;24(3):340-55.

Pritchard MT, McMullen MR, Stavitsky AB, Cohen JI, Lin F, Medof ME, et al. Differential contributions of $\mathrm{C} 3, \mathrm{C} 5$, and decay-accelerating factor to ethanol-induced fatty liver in mice. Gastroenterology. 2007 Mar;132(3):1117-26.

Que-Gewirth NL, Ribeiro AA, Kalb SR, Cotter RJ, Bulach DM, Adler B, et al. A methylated phosphate group and four amide-linked acyl chains in leptospira interrogans lipid A. The membrane anchor of an unusual lipopolysaccharide that activates TLR2. J Biol Chem. 2004;279(24):25420-9.

Santos CS, Macedo JO, Bandeira M, Chagas-Junior AD, McBride AJ, McBride FW, et al. Different outcomes of experimental leptospiral infection in mouse strains with distinct genotypes. J Med Microbiol. 2010;59(Pt 9):1101-6.

Sarkar U, Nascimento SF, Barbosa R, Martins R, Nuevo H, Kalofonos I, et al. Populationbased case-control investigation of risk factors for leptospirosis during an urban epidemic. Am J Trop Med Hyg. 2002;66(5):605-10. 
Scola AM, Higginbottom A, Partridge LJ, Reid RC, Woodruff T, Taylor SM, et al. The role of the N-terminal domain of the complement fragment receptor C5L2 in ligand binding. J Biol Chem. 2007;282(6):3664-71.

Selleri C, Sato T, Anderson S, Young NS, Maciejewski JP. Interferon-gamma and tumor necrosis factor-alpha suppress both early and late stages of hematopoiesis and induce programmed cell death. J Cell Physiol. 1995;165(3):538-46.

Shah I, Katira B. Clinical and laboratory profile of dengue, leptospirosis and malaria in children: a study from Mumbai. Arch Dis Child. 2007;92(6):561.

Silva AS, Valencia MM, Cianciarullo AM, Vasconcellos SA, Barbosa AS, Isaac L. Interaction of human complement factor $\mathrm{H}$ variants $\mathrm{Tyr}^{40_{2}}$ and $\mathrm{His}^{40_{2}}$ with Leptospira spp. Front Immunol. 2011;2:1-8.

Snyderman R, Phillips JK, Mergenhagen SE. Biological activity of complement in vivo. Role of $\mathrm{C} 5$ in the accumulation of polymorphonuclear leukocytes in inflammatory exudates. J Exp Med. 1971;134(5):1131-43.

Stefos A, Georgiadou SP, Gioti C, Loukopoulos A, Ioannou M, Pournaras S, et al. Leptospirosis and pancytopenia: two case reports and review of the literature. J Infect. 2005;51(5):e277-80.

Strainic MG1, Liu J, Huang D, An F, Lalli PN, Muqim N, et al. Locally produced complement fragments $\mathrm{C} 5 \mathrm{a}$ and $\mathrm{C} 3 \mathrm{a}$ provide both costimulatory and survival signals to naive $\mathrm{CD}^{+}{ }^{+} \mathrm{T}$ cells. Immunity. 2008;28(3):425-35.

Strey CW, Markiewski M, Mastellos D, Tudoran R, Spruce LA, Greenbaum LE, et al. The proinflammatory mediators $\mathrm{C} 3 \mathrm{a}$ and $\mathrm{C} 5 \mathrm{a}$ are essential for liver regeneration. J Exp Med. 2003;198(6):913-23.

Tajiki H, Salomão R. Association of plasma levels of tumor necrosis factor alpha with severity of disease and mortality among patients with leptospirosis. Clin Infect Dis. 1996;23(5):1177-8.

Thorley JD, Smith JW, Luby JP, Sanford JP. Peripheral blood lymphocyte response to acute infections in humans. Infect Immun. 1977;16(1):110-4.

Vernel-Pauillac F, Goarant C. Differential cytokine gene expression according to outcome in a hamster model of leptospirosis. PLoS Negl Trop Dis. 2010;4(1):e582.

Vijayachari P, Sugunan AP, Shriram AN. Leptospirosis: an emerging global public health problem. J Biosci. 2008;33(4):557-69.

Viriyakosol S, Matthias MA, Swancutt MA, Kirkland TN, Vinetz JM. Toll-like receptor 4 protects against lethal Leptospira interrogans serovar icterohaemorrhagiae infection and contributes to in vivo control of leptospiral burden. Infect Immun. 2006;74(2):887-95.

Walport MJ. Complement. First of two parts. N Engl J Med. 2001 ;344(14):1058-66. 
Ward PA, Zvaifler NJ. Complement-derived leukotactic factors in inflammatory synovial fluids of humans. J Clin Invest. 1971;50(3):606-16.

Weil A. Ueber eine eigentümliche, mit milztumor, icterus und nephritis einhergehende akute infektionskrankheit. Dtsche. Arch. Klin. Med. 1886;39:209-32.

Werts C, Tapping RI, Mathison JC, Chuang TH, Kravchenko V, Saint Girons I, et al. Leptospiral lipopolysaccharide activates cells through a TLR2-dependent mechanism. Nat Immunol. 2001;2(4):346-52.

Wetsel RA, Fleischer DT, Haviland DL. Deficiency of the murine fifth complement component (C5). A 2-base pair gene deletion in a 5'-exon. J Biol Chem. 1990;265(5):2435-40.

Whitney MA, Royle G, Low MJ, Kelly MA, Axthelm MK, Reifsteck C, et al. Germ cell defects and hematopoietic hypersensitivity to gamma-interferon in mice with a targeted disruption of the Fanconi anemia C gene. Blood. 1996;88(1):49-58.

Xu DZ, Zaets SB, Chen R, Lu Q, Rajan H, Yang X, et al. Elimination of C5aR prevents intestinal mucosal damage and attenuates neutrophil infiltration in local and remote organs. Shock. 2009;31(5):493-9.

Xue F, Zhao X, Yang Y, Zhao J, Yang Y, Cao Y, et al. Responses of murine and human macrophages to leptospiral infection: a study using comparative array analysis. PLoS Negl Trop Dis. 2013;7(10):e2477.

Zipfel PF, Skerka C. Complement regulators and inhibitory proteins. Nat Rev Immunol. 2009;9(10):729-40. 


\section{APÊNDICE - Publicações}

\section{Basal physiological parameters of two congenic mice strains: $\mathrm{C} 5$ deficient C57BL/6 and C5 sufficient A/J}

Lorena Bavia, Íris Arantes de Castro, Silvia Maria Gomes Massironi, Lourdes Isaac*

Department of Immunology, Institute of Biomedical Sciences, University of São Paulo, Brazil

\section{A R T I C L E I N F O}

\section{Article history:}

Received 3 January 201

Received in revised form 12 February 201

Accepted 26 February 2014

Available online 7 March 2014

\section{Keywords:}

Complement system

C5

Cholesterol

Triglycerides

Liver enzym

Albumin

\section{A B S T R A C T}

To investigate the in vivo role of complement component C5 it is common to compare the inflammatory response between C5-normal and C5-deficient inbred mice strains. Nevertheless, it should be expected that differences in the genetic backgrounds between those strains may affect several physiological parameters, complicating the correct interpretation of results. The use of congenic mice, developed by backcrossing, is therefore preferred. Still, several physiological parameters may be distinctive in the normal and deficient strains and therefore require careful analysis before animals are selected for investigation. We tigationtal $B$ C5 strin and $\mathrm{AJ} \mathrm{C5}^{2}$ miced derivetide sequencing, inmunodiffusion and hemicological parameter were analyzed in the congenic and parental strains before antigen exposition. Serum levels of liver alanine aminotransferase, alkaline phosphatase, albumin, triglycerides, cholesterol and uric acid were found to be different in C5-sufficient and C5-deficient mice from one or both genetic backgrounds (B6 and/o $\mathrm{A} / \mathrm{J}$ ). On the other hand, serum levels of liver aspartate aminotransferase, glucose and urea were not affected by the presence of $\mathrm{C} 5$ in either strain. Furthermore, in some cases, C5-dependent variations in these parameters were more evident in mice of the same gender. We conclude here that C5-deficient mice strains may present distinct systemic behaviors which should be taken in consideration before differences in the immune responses are attributed solely to the lack of circulating C5.

○ 2014 Elsevier B.V. All rights reserved.

\section{Introduction}

The complement system is important for the innate and acquired immune response and the component $\mathrm{C} 5$ is essential for complement activation mediated by classic, alternative and lectin pathways [1]. C5 may be cleaved by C5-convertase and generates fragment C5a (which binds to cell membrane receptors C5aR and C5L2) and fragment C5b. The clinical importance of this component is evident from the observation that C5 deficient patients are highly susceptible to develop recurrent and severe infections mainly caused by microorganisms such as Neisseria meningitidis $[2,3]$. Several research groups investigate the biological roles of C5derived molecules in vitro and in vivo in the inflammatory response,

* Corresponding author at: Departamento de Imunologia, Instituto de Ciências Biomédicas, Universidade de São Paulo. Av. Prof. Lineu Prestes 1730 - Cidade Universitária, Sảo Paulo, SP CEP $05508-900$, Brazil Tel : +551130917390; : +551130917224

E-mailaddress: louisaac@icb.usp.br(L. Isaac). visioning possible therapeutic applications to control important pathologies triggered by the complement system [4].

$\mathrm{A} / \mathrm{J}, \mathrm{A} / \mathrm{He}, \mathrm{AKR}, \mathrm{DBA} / 2, \mathrm{NZB} / \mathrm{B} 1 \mathrm{~N}$ and B10.D2/oSn mice strains are C5 deficient due to a 2 nucleotide (TA) deletion close to the $5^{\prime}$ end of exon 7 in the $c 5$ gene $[5,6]$ located on chromosome 2 [7]. This mutation generates a premature stop codon (TAG) located 4 bases after the deletion site which explains the lack of $\mathrm{C} 5$ in these mice.

To evaluate the in vivo role of $\mathrm{C}_{5}$ in the immune response, many experiments are usually performed in inbred mice strains with normal levels of C5 (ex: C57BL/6, BALB/C, DBA/1 and B10.D2/nSn) and compared to C5 deficient strains. However, differences in genetic background may possibly affect the correct interpretation of data. To circumvent this limitation, some studies have employed congenic mice strains in which a mutant (or wild type) $c 5$ gene is introduced after several rounds of backcrossing with the parental strain $[8-10]$. The use of congenic mice strains based on C57BL/6 or $\mathrm{A} / \mathrm{J}$ backgrounds have explored different biological phenomena such as the immune response to infectious diseases [11-13], bone marrow cellular composition [14] and drug-induced psychomotor activities [15]. 